July 2002 • NREL/TP-520-31267

\title{
Review of Mid- to High- Temperature Solar Selective Absorber Materials
}

C.E. Kennedy

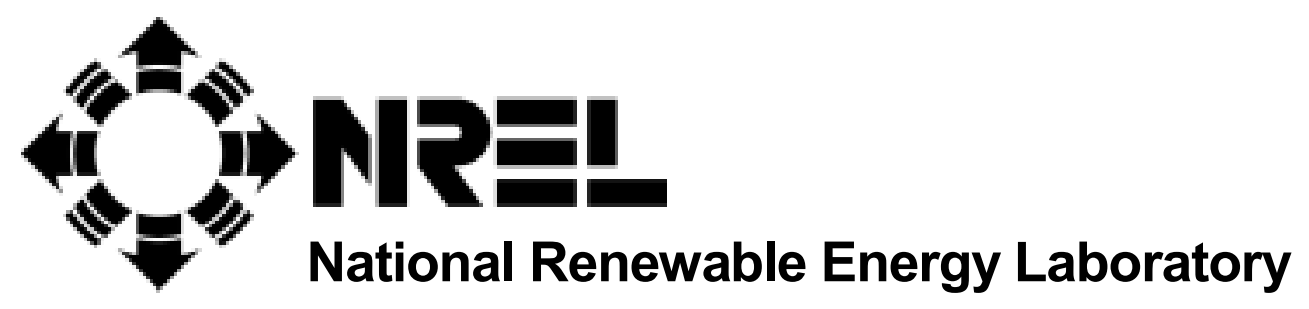

1617 Cole Boulevard

Golden, Colorado 80401-3393

NREL is a U.S. Department of Energy Laboratory

Operated by Midwest Research Institute $\bullet$ Battelle $\bullet$ Bechtel

Contract No. DE-AC36-99-G010337 


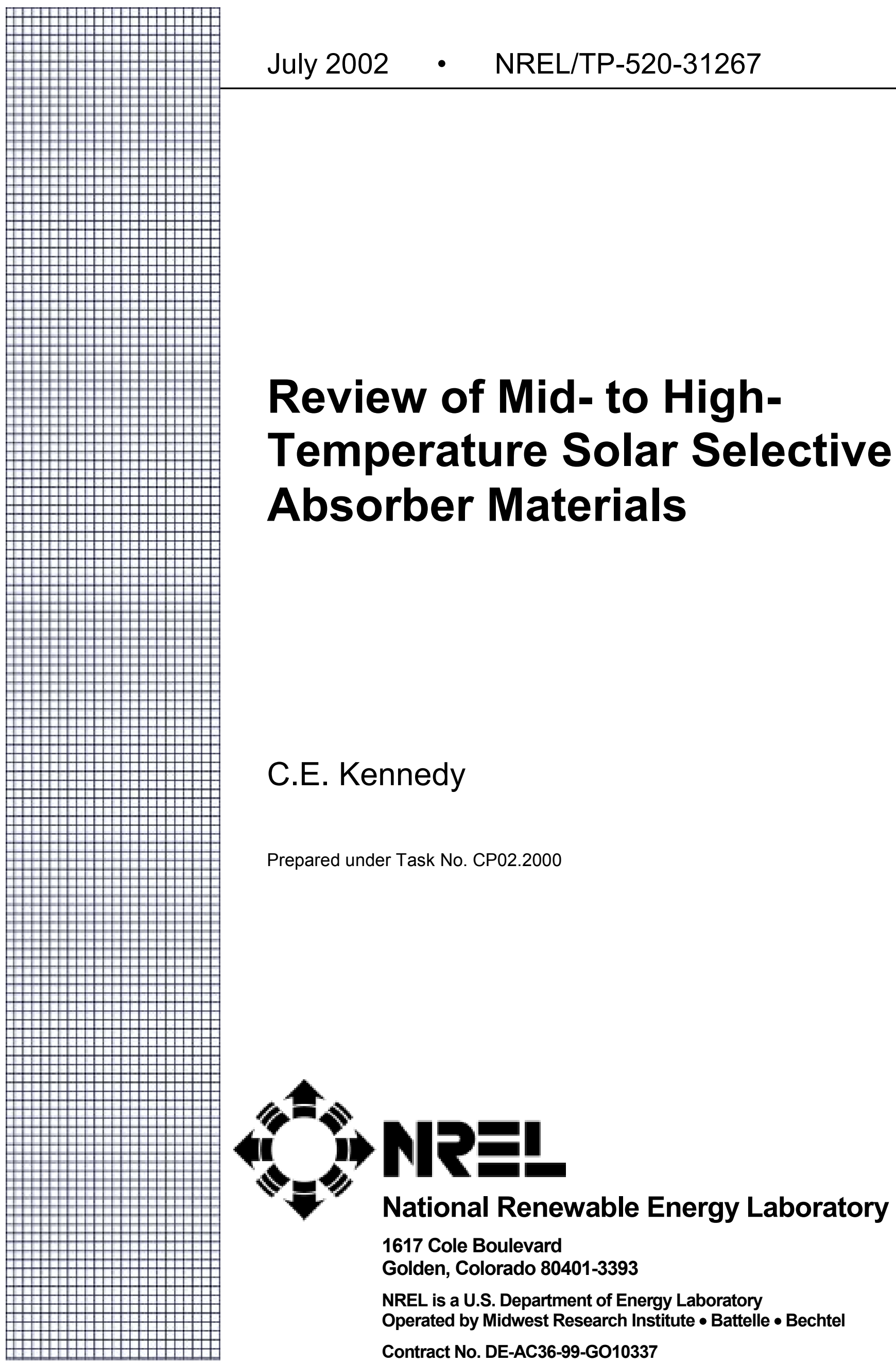




\section{NOTICE}

This report was prepared as an account of work sponsored by an agency of the United States government. Neither the United States government nor any agency thereof, nor any of their employees, makes any warranty, express or implied, or assumes any legal liability or responsibility for the accuracy, completeness, or usefulness of any information, apparatus, product, or process disclosed, or represents that its use would not infringe privately owned rights. Reference herein to any specific commercial product, process, or service by trade name, trademark, manufacturer, or otherwise does not necessarily constitute or imply its endorsement, recommendation, or favoring by the United States government or any agency thereof. The views and opinions of authors expressed herein do not necessarily state or reflect those of the United States government or any agency thereof.

Available electronically at http://www.osti.gov/bridge

Available for a processing fee to U.S. Department of Energy

and its contractors, in paper, from:

U.S. Department of Energy

Office of Scientific and Technical Information

P.O. Box 62

Oak Ridge, TN 37831-0062

phone: 865.576.8401

fax: 865.576.5728

email: reports@adonis.osti.gov

Available for sale to the public, in paper, from:

U.S. Department of Commerce

National Technical Information Service

5285 Port Royal Road

Springfield, VA 22161

phone: 800.553.6847

fax: 703.605.6900

email: orders@ntis.fedworld.gov

online ordering: http://www.ntis.gov/ordering.htm 


\section{Table of Contents}

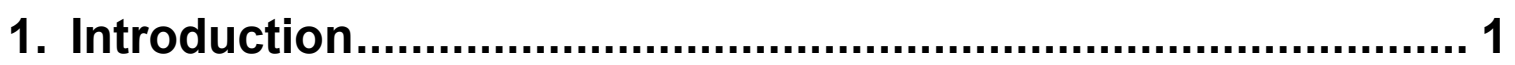

2. Characterization of Selective Surfaces ................................. 2

3. Description of Types of Absorbers ........................................... 4

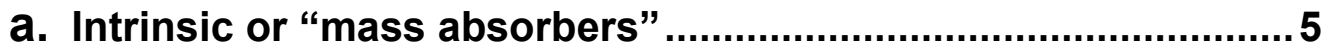

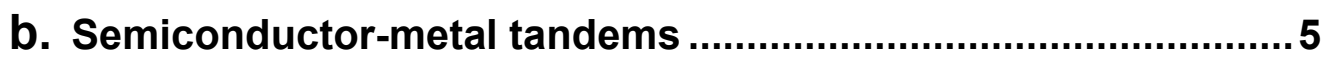

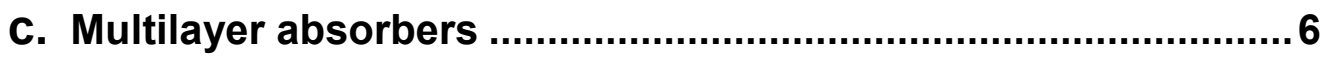

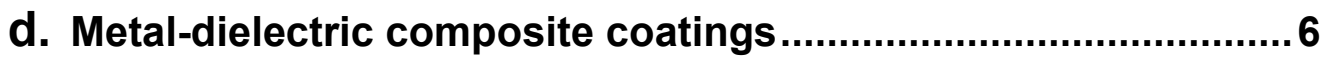

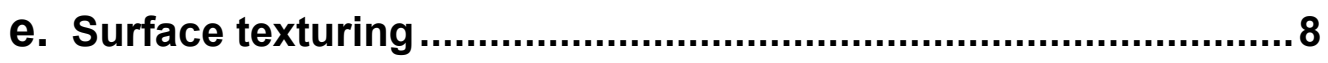

f. Selectively solar-transmitting coating on a blackbody-like

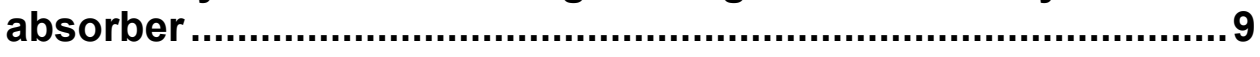

4. Temperature Range of Absorber Materials............................ 9

4.1. Mid-temperature selective surfaces $\left(100^{\circ} \mathrm{C}<\mathrm{T}<400^{\circ} \mathrm{C}\right) \ldots \ldots . . .13$

4.2. High-temperature selective surfaces $\left(T>400^{\circ} \mathrm{C} \ldots \ldots . . . . . . . . . . . . . . .19\right.$

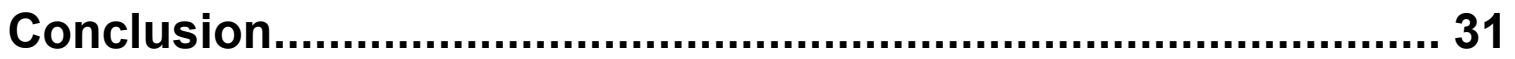

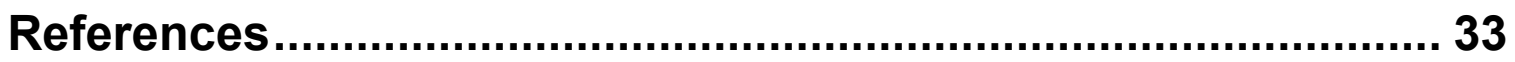

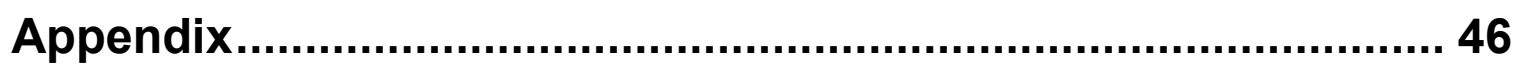

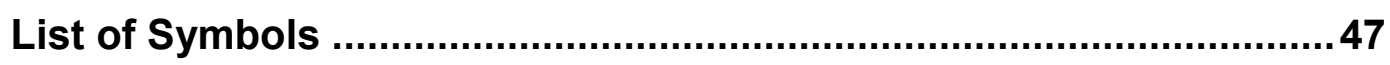

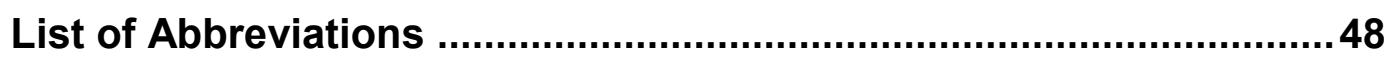

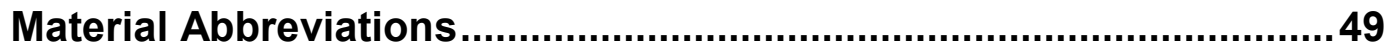

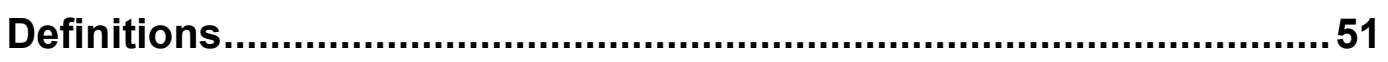




\section{List of Figures}

Figure 1. Spectral performance of an ideal selective solar absorber

Figure 2. Spectral Emittance as a function of sample temperature for aluminum

Figure 3. Schematic designs of six types of coatings and surface treatments for selective absorption of energy

Figure 4. Schematic designs of multilayer absorber film structure

Figure 5. Schematic designs of two different metal-dielectric solar selective coating

Figure 6. Schematic design of double-cermet film structure

\section{List of Tables}

Table 1. Mid-Temperature Selective Surfaces

Table 2. High-Temperature Selective Surfaces 12

Table 3. Multilayer Selective Surfaces $\quad 20$

Table 4. Composition and Properties of Selected $\mathrm{MC}_{\mathrm{x}} \mathrm{O}_{\mathrm{y}} \mathrm{N}_{\mathrm{z}}$ absorbers 27 


\section{Introduction}

Concentrating solar power (CSP) systems use solar absorbers to convert sunlight to thermal electric power. The CSP program is working to reduce the cost of parabolic trough solar power technology. One of the approaches is to increase the operating temperature of the solar field from approximately $400^{\circ} \mathrm{C}$ to $500^{\circ} \mathrm{C}$ (or higher). To accomplish this, new more efficient selective coatings are needed that have both high solar absorptance and low thermal emittance at $500^{\circ} \mathrm{C}$. Although designs are likely to use coating in evacuated environments, the coatings need to be stable in air in case the vacuum is breached. Current coatings to not have the stability and performance desired for moving to higher operating temperatures. For efficient photothermal conversion solar absorber surfaces must have high solar absorptance $(\alpha)$ and a low thermal emittance $(\varepsilon)$ at the operational temperature. A low reflectance $(\rho \approx 0)$ at wavelengths $(\lambda) \leq 3 \mu \mathrm{m}$ and a high reflectance $(\rho \approx 1)$ at $\lambda \geq 3 \mu \mathrm{m}$ characterize spectrally selective surfaces, as shown in Figure 1. The cutoff may be higher or lower as it is dependent on the temperature. The operational temperature ranges of these materials for solar applications can be categorized as low temperature $\left(\mathrm{T}<100^{\circ} \mathrm{C}\right)$, mid temperature $\left(100^{\circ} \mathrm{C}<\mathrm{T}<400^{\circ} \mathrm{C}\right)$, and high temperature $\left(\mathrm{T}>400^{\circ} \mathrm{C}\right)$. CSP systems operate at high- and mid-temperatures. For CSP parabolic trough applications, the ideal spectrally selective surface would be low-cost and easy to manufacture, chemically and thermally stable in air at elevated temperatures $(\mathrm{T} \geq$ $500^{\circ} \mathrm{C}$ ), and have a solar absorptance $\geq 0.98$ and a thermal emittance $\leq 0.05$ at $500^{\circ} \mathrm{C}$. However, a high temperature coating may require tradeoffs in performance as the high solar absorption and low emittance may be mutually exclusive.

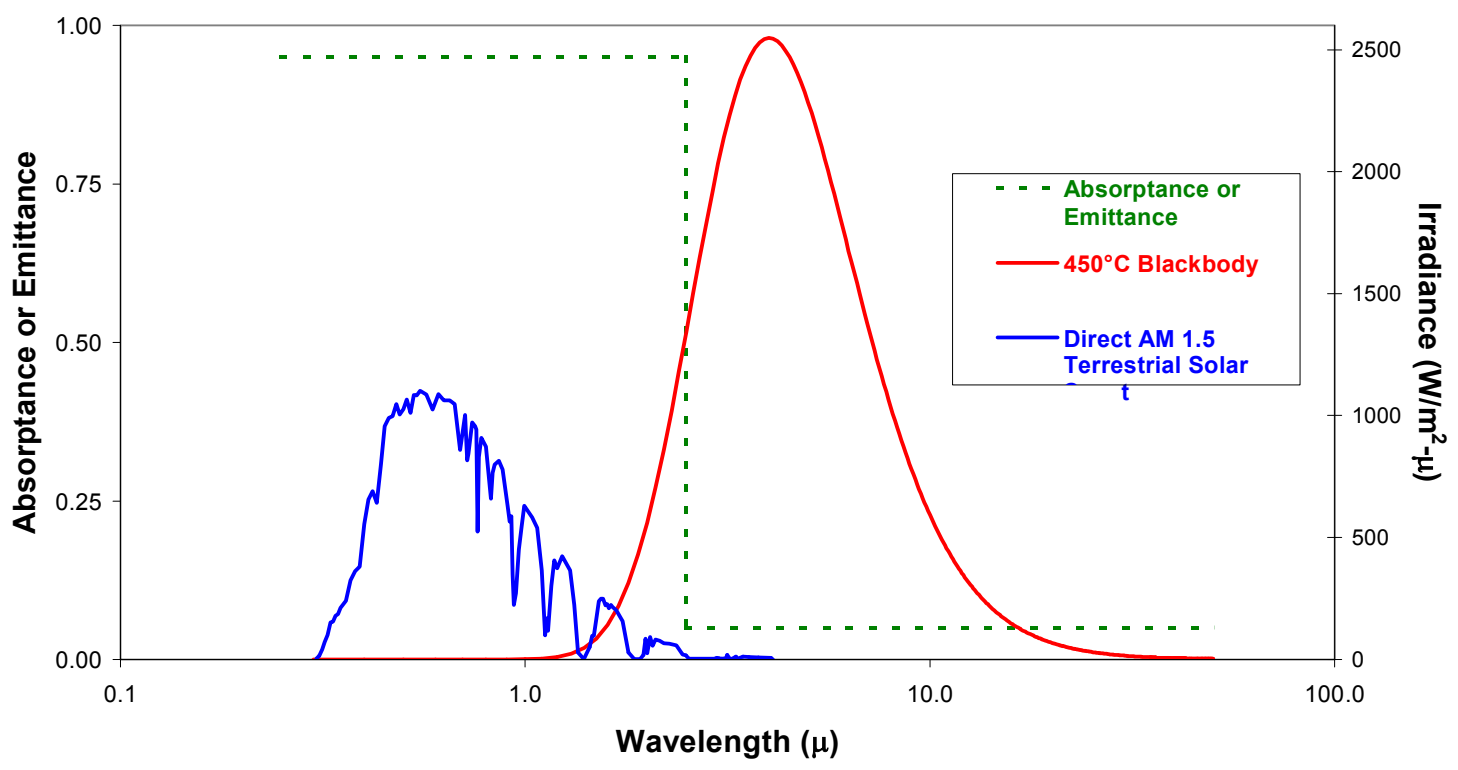

Figure 1. Spectral performance of an ideal selective solar absorber. 


\section{Characterization of Selective Surfaces}

The performance of a candidate solar absorber can be characterized by its solar absorptance and thermal emittance. Using Kirchoff's law, spectral absorptance can be expressed in terms of total reflectance $\rho(\lambda, \theta)$ for opaque materials,

and

$$
\alpha(\lambda, \theta)=1-\rho(\lambda, \theta)
$$

$$
\varepsilon(\lambda, T)=\alpha(\lambda, T),
$$

where $\rho(\lambda, \theta)$ is the sum of both collimated and diffuse reflectance, $\lambda$ is the wavelength, $\theta$ is the incidence angle of light, and $\mathrm{T}$ is the given temperature. Development of spectrally selective materials depends on reliable characterization of their optical properties. Using standard spectrophotometers, solar reflectance is usually measured in the 0.3-2.5 $\mu \mathrm{m}$ wavelength range at near-normal $\theta=0$ angle of incidence. "By experience, this leads to unrealistic predictions of high efficiencies at high temperatures because the emittances are systematically underestimated [1]." Emittance is typically measured at room temperature, though it can be measured at other temperatures. Emittance is frequently reported from reflectance data fitted to blackbody curves

$$
\varepsilon(T)=\frac{\int_{\lambda_{\min }=0}^{\lambda_{\max }=\infty}[1-\rho(\lambda, T)] B(\lambda, T) d \lambda}{\sigma T^{4}}
$$

where $\sigma=5.6696 \times 10^{-8} \mathrm{Wm}^{-2} \mathrm{~K}^{-4}$ is the Stefan-Boltzmann constant and $\mathrm{B}(\lambda, \mathrm{T})$ is the spectral irradiance of a blackbody curve from

$$
B(\lambda, T)=\frac{c_{1}}{\lambda^{5}\left[e^{\left(\frac{c 2}{\lambda T}\right)}-1\right]},
$$

where $\mathrm{c}_{1}=3.7405 \times 10^{8} \mathrm{~W} \mathrm{~m}^{4} \mathrm{~m}^{-2}$ and $\mathrm{c}_{2}=1.43879 \times 10^{4} \mu \mathrm{m} \mathrm{K}$, which are Planck's first and second radiation constants, respectively. The actual performance of an absorber at high temperatures may not correspond to the calculated emittance. This is because small errors in measured $\rho$ can lead to large errors in small values of $\varepsilon$ [2]. In addition, for some materials the measured emittance data at two different temperatures may simply be different. For example, at $\lambda_{\max }$, the blackbody wavelength maximum for a specific temperature,

$$
\lambda_{\max }(\mu) \times \mathrm{T}(\mathrm{K})=2898(\mu \mathrm{K}),
$$

the largest difference is seen between the spectral emittance of aluminum at $25^{\circ} \mathrm{C}$ and $149^{\circ} \mathrm{C}$, as shown in Figure 2 [3]. The emittance must therefore be measured at temperatures expected during working conditions. 


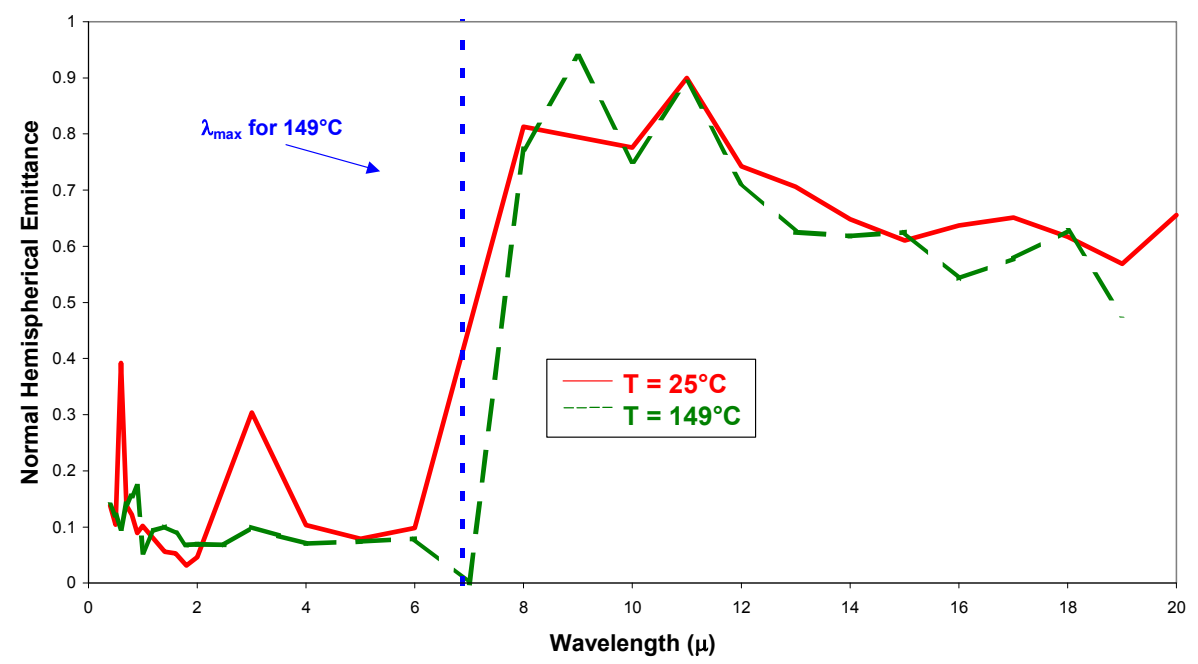

Figure 2. Spectral Emittance as a function of sample temperature for aluminum.

Emittance is a surface property and depends on the surface condition of the material, including the surface roughness, surface films, and oxide layers [4]. Coatings typically replicate to some degree the surface roughness of the substrate. Therefore to facilitate development, it is important to measure the emittance of each coating-substrate combination as well as the uncoated substrate when developing a solar selective coating. Furthermore, selective coatings can degrade at high temperatures because of thermal load (oxidation), high humidity or water condensation on the absorber surface (hydratization and hydrolysis), atmospheric corrosion (pollution), diffusion processes (interlayer substitution), chemical reactions, and poor interlayer adhesion [5,6]. Calculating the emittance from spectral data taken at room temperature assumes that the spectral characteristics do not change with increasing temperature. This is only valid if the material is invariant and does not undergo a phase change (as do some titanium containing materials), breakdown or undergo oxidation (as do paints and some oxide coatings) at higher temperatures. It is important before using high-temperature emittance calculated from room temperature data, that the calculated data is verified with hightemperature emittance measurements for each selective coating. The key for hightemperature usage is low $\varepsilon$, because the thermal radiative losses of the absorbers increase proportionally by the fourth power of temperature; therefore, it is important to measure the emittance at the operating temperatures and conditions [2].

In addition to the initial efficiency, long term stability is also an important requirement for absorber coatings. At high temperatures, thermal emittance is the dominant source of losses, and the requirement of low emittance often leads to complex designs that are frequently susceptible to degradation at the working temperature. There is an International Energy Agency (IEA) Task X performance criterion (PC) developed for flat-plate collector selective absorber testing (i.e., non-concentrating, 1-2X sunlight intensity). The PC describes the influence in the change of solar absorption $\left(\Delta \alpha_{\mathrm{s}}\right)$ and emittance $(\Delta \varepsilon)$ on the solar fraction:

$$
P C=-\Delta \alpha_{s}+0.25 \bullet \Delta \varepsilon \leq 0.05,
$$


assuming a service lifetime of at least 25 years and a decrease in the annual solar fraction of $5 \%$. Service lifetime testing for this criterion is performed by exposing the absorber coatings for $200 \mathrm{~h}$ at $250^{\circ} \mathrm{C}$. If the material survives, it is then exposed for $75 \mathrm{~h}$ at $300^{\circ} \mathrm{C}$, followed by $600 \mathrm{~h}$ at $40^{\circ} \mathrm{C} / 95 \%$ relative humidity $(\mathrm{RH})$, then $85 \mathrm{~h}$ at $60^{\circ} \mathrm{C} / 95 \% \mathrm{RH}[5,7]$. After exposure testing, the emittance is typically measured at $100^{\circ} \mathrm{C}$.

No similar criterion has been developed for testing the service lifetime of hightemperature absorbers for CSP applications. Thermal stability is sometimes based on the thermal properties of the individual materials or the processing temperature parameters, and actual durability data are rarely known for high-temperature absorber coatings. Durability or thermal stability is typically tested by heating the selective coating, typically in a vacuum oven but sometimes in air, for a relatively short duration (100s of hours) compared to the desired lifetime (5-30 years). This procedure often masks cascaded processes and interactions during exposure [8]. Degradation of hightemperature absorbers usually causes increasing emittance; therefore, emittance is a sensitive indicator to monitor degradation in the normal case where emittance changes with exposure. In addition, while the emittance of many materials after exposure to high temperatures does not return to the original emittance measured (e.g., paint), for some materials (e.g., Boral, a malleable boron-aluminum alloy) the emittance changes at high temperatures and returns to the original value after cooling to room temperature. Therefore, it is important to verify for each selective coating that the emittance does not change during the heat cycle. The capability must be built to allow spectrally selective coatings to be exposed and measured at their operating temperatures and conditions for longer periods of time to determine the durability and thermal stability of the materials. Then a criterion needs to be developed for high-temperature selective surfaces applicable for concentrating applications.

\section{Description of Types of Absorbers}

Selective absorber surface coatings can be categorized into six distinct types: a) intrinsic, b) semiconductor-metal tandems, c) multilayer absorbers, d) multi-dielectric composite coatings, e) textured surfaces, and f) selectively solar-transmitting coating on a blackbody-like absorber. Intrinsic absorbers use a material having intrinsic properties that result in the desired spectral selectivity. Semiconductor-metal tandems absorb short wavelength radiation because of the semiconductor bandgap and have low thermal emittance as a result of the metal layer. Multilayer absorbers use multiple reflections between layers to absorb light and can be tailored to be efficient selective absorbers. Metal-dielectric composites - cermets - consist of fine metal particles in a dielectric or ceramic host material. Textured surfaces can produce high solar absorptance by multiple reflections among needle-like, dendritic, or porous microstructure. Additionally, selectively solar-transmitting coatings on a blackbody-like absorber are also used but are typically used in low-temperature applications. These constructions are shown schematically in Figures 3a-f, respectively, and are discussed in greater detail below. 


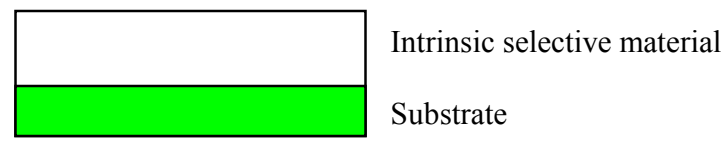

a) Intrinsic absorber

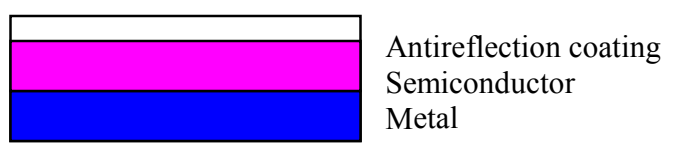

b) Semiconductor-metal tandems

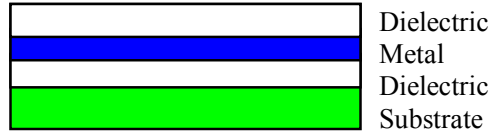

c) Multilayer absorbers

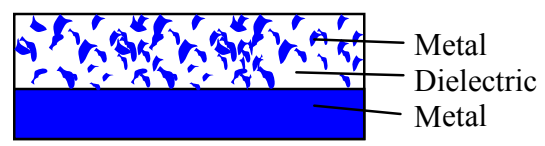

d) Metal-dielectric composite

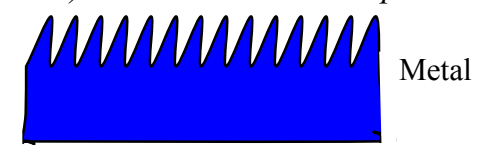

e) Surface texturing

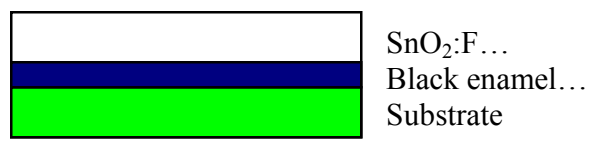

f) Solar-transmitting coating/blackbody-like absorber

Figure 3. Schematic designs of six types of coatings and surface treatments for selective absorption of energy.

\section{a) Intrinsic or "mass absorbers"}

Intrinsic or "mass absorbers," in which selectivity is an intrinsic property of the materials, are structurally more stable but optically less effective than multilayer stacks examples include, metallic $\mathrm{W}$ [9], $\mathrm{MoO}_{3}$-doped Mo [10], Si doped with $\mathrm{B}, \mathrm{CaF}_{2}$ [11], $\mathrm{HfC}$ [12], $\mathrm{ZrB}_{2}$ [13], $\mathrm{SnO}_{2}$ [12], $\mathrm{In}_{2} \mathrm{O}_{3}$ [11], $\mathrm{Eu}_{2} \mathrm{O}_{3}$ [14], $\mathrm{ReO}_{3}$ [14], $\mathrm{V}_{2} \mathrm{O}_{5}$ [14], and $\mathrm{LaB}_{6}$ [15]. No naturally occurring material exhibits intrinsically ideal solar-selective properties, but some roughly approximate selective properties. Intrinsic solar-selective properties are found in transition metals and semiconductors, but both need to be greatly modified to serve as an intrinsic absorber. Hafnium carbide (HfC) could be useful as an absorbing selective surface at elevated temperatures because of its high melting point. However, HfC requires structural and/or compositional changes in the lattice or an antireflective (AR) layer composed of a quarter wavelength of a dielectric material to create the required properties. Single-layer AR coatings that have been used include $\mathrm{SiO}$, $\mathrm{SiO}_{2}, \mathrm{Si}_{3} \mathrm{~N}_{4}, \mathrm{TiO}_{2}, \mathrm{Ta}_{2} \mathrm{O}_{5}, \mathrm{Al}_{2} \mathrm{O}_{3}, \mathrm{ZrO}_{2}, \mathrm{Nd}_{2} \mathrm{O}_{3}, \mathrm{MgO}, \mathrm{MgF}_{2}$, and $\mathrm{SrF}_{2}$ [16,17]. AR coatings can also be made from very thin layers of two materials having properly matched indices of refraction, for example, thallium iodide and lead fluoride [18]. Historically, research in intrinsic absorbers has not been very productive because there are no ideal intrinsic materials; but the intrinsic materials are finding increasing use as a component in high-temperature absorber multilayers and composite coatings.

\section{b) Semiconductor-metal tandems}

Semiconductors with bandgaps from about $\sim 0.5 \mathrm{eV}(2.5 \mu \mathrm{m})$ to $1.26 \mathrm{eV}(1.0 \mu \mathrm{m})$ absorb short-wavelength radiation, and the underlying metal provides low emittance to give the desired spectral selelectivity to semiconductor-metal tandems. Semiconductors of interest include $\mathrm{Si}(1.1 \mathrm{eV}), \mathrm{Ge}(0.7 \mathrm{eV})$, and $\mathrm{PbS}(0.4 \mathrm{eV})$ [19]. Thin semiconductor films of high porosity or antireflection coatings are needed because the useful semiconductors have high refractive indices, which result in large detrimental reflectance 
losses. Si-based designs produced by chemical-vapor deposition (CVD) are well known that are suitable for mid- to high-temperature applications [20].

\section{c) Multilayer absorbers}

Multilayer absorbers or multilayer interference stacks can be designed so that they become efficient selective absorbers. The selective effect is because the multiple reflectance passes through the bottom dielectric layer (E) and is independent of the selectivity of the dielectric. A thin semitransparent reflective layer (D), typically a metal, separates two quarter-wave dielectric layers (C and E). The bottom-reflecting layer (D) has high reflectance in the infrared (IR) region and is slightly less reflective in the visible region. The top dielectric layer $(\mathrm{C})$ reduces the visible reflectance. The thickness of this dielectric determines the shape and position of the reflectance curve. An additional semitransparent (i.e., thin) metal layer (B) further reduces the reflectance in the visible region, and an additional dielectric layer $(\mathrm{A})$ increases the absorption in the visible region and broadens the region of high absorption. The basic physics of the multilayer absorber is well understood, and computer modeling can easily compute the optical properties given by an optimum multilayer design of candidate materials [21,22]. Multilayer interference stacks have high solar absorption, low thermal emittance, and are stable at elevated temperatures $\left(\geq 400^{\circ} \mathrm{C}\right)$ depending on the materials used. Several multilayer absorbers using different metals (e.g., $\mathrm{Mo}, \mathrm{Ag}, \mathrm{Cu}, \mathrm{Ni}$ ) and dielectric layers (e.g., $\mathrm{Al}_{2} \mathrm{O}_{3}$, $\mathrm{SiO}_{2}, \mathrm{CeO}_{2}, \mathrm{ZnS}$ ) have been cited in the literature for high-temperature applications [23].

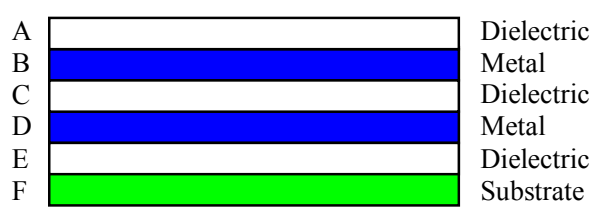

Figure 4. Schematic designs of multilayer absorber film structure.

\section{d) Metal-dielectric composite coatings}

Metal-dielectric composite coatings or absorber-reflector tandems have a highly absorbing coating in the solar region (i.e., black) that is transparent in the IR, deposited onto a highly IR-reflective metal substrate. The highly absorbing metal-dielectric composite, or cermet, consists of fine metal particles in a dielectric or ceramic matrix, or a porous oxide impregnated with metal. These films are transparent in the thermal IR region, while they are strongly absorbing in the solar region because of interband transitions in the metal and the small particle resonance. When deposited on a highly reflective mirror, the tandem forms a selective surface with high solar absorptance and low thermal emittance. The high absorptance may be intrinsic, geometrically enhanced, or both. The absorbing cermet layer comprised of inherently high-temperature materials can have either a uniform or graded metal content. The metal-dielectric concept offers a high degree of flexibility, and the solar selectivity can be optimized by proper choice of constituents, coating thickness, particle concentration, size, shape, and orientation. The 
solar absorptance can be boosted with a suitable choice of substrates and AR layers, which can also provide protection (for example, from thermal oxidative degradation). A variety of techniques, such as electroplating, anodization, inorganic pigmentation of anodized aluminum, CVD, and co-deposition of metal and insulator materials by physical vapor deposition (PVD), can produce the composite coatings. A subclass of this category is a powdered semiconductor-reflector combination, where the solar-selective properties of semiconductor, inorganic metal oxides, organic black pigments, and metal-dustpigmented selective paints can be considered.

Metal-pigmented alumina selective coatings use oxide coatings obtained from the phosphoric anodic anodization of aluminum. The oxide coating has two parts (Figure 5a) consisting of a compact barrier layer and a porous alumina layer whose pores are perpendicular to the aluminum. The pores can be impregnated with $\mathrm{Ni}, \mathrm{V}, \mathrm{Cr}, \mathrm{Co}, \mathrm{Cu}$, $\mathrm{Mo}, \mathrm{Ag}$, and $\mathrm{W}$ as rod-like particles 30-50 $\mathrm{nm}$ in diameter and $300 \mathrm{~nm}$ long [24].

In a graded cermet (Figure 5b), the reflectance from the cermet is reduced by gradually increasing the metal volume fraction, hence the refractive index, as a function of depth from the surface to the base of the film. PVD or CVD techniques can be used for most graded cermets. By controlling the PVD deposition parameters, the microstructure of the oxides can be deposited with a porous to columnar microstructure, and by codeposition the inclusions or pores can be filled with metal by evaporation or sputtering. For example, in the art of thin-film growth, it is well known that columnar microstructure will grow depending on the material itself and the deposition conditions - substrate temperature, deposition rate, vacuum pressure, and angle of incidence.

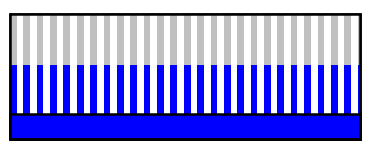

(a)

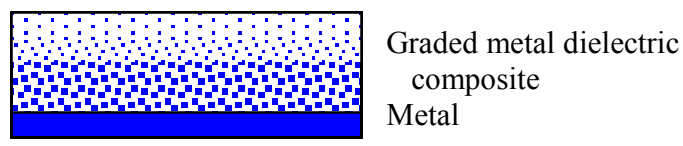

(b)

Figure 5. Schematic designs of two different metal-dielectric solar selective coating.

In cermets, solar absorptance is mainly determined by the response of the absorbing particles. There is a shift of the absorption and scattering cutoffs to higher wavelengths when the particle radius, $r$, increases this effect is accompanied by a reduction in the maximum of the scattering and absorption efficiencies roughly proportional to $r^{-1}$ [25]. Thicker cermets are needed to reach the same low reflectance in the visible region as seen for larger particles. Thermal emittance strongly increases as the thickness of the cermet increases due to IR absorption. Reducing the thickness and increasing the metallic concentration in the same proportion can reduce emittance. The optimum pore diameter, $d_{p}=0.08 \mu \mathrm{m}$, of nickel-pigmented alumina coatings have been determined by kinetic studies, but the results have not been incorporated into the material [25]. Much smaller particles rely on interference effects and are more sensitive to thickness variations. The optical properties of the cermets can be improved by using the optimum cermet thickness and particle diameter. Oxidation of the rods in alumina occurs from the end of the particle facing the pore opening, and the rate of oxidization is similar to bulk oxidization [26]. The matrix reduces the rate of oxidation at $300^{\circ} \mathrm{C}$ by $75 \%$ of the dendrite alone [27]. Alumina is well known as a ceramic stable at high temperature, but $\mathrm{SiO}_{2}$ and $\mathrm{AlN}$ have also been used [28]. In addition, $\mathrm{ZrO}_{2}$ films could find applications 
as the dielectric medium in cermets, as multilayer solar-selective absorbers, or as AR coatings because of its high refractive index, high dielectric constant, low thermal conductivity, and corrosion-resistant properties [29,30]. Using metals with a slower oxidation rate or ceramic binders stable at high temperatures would increase the durability of the cermet.

A double-cermet film structure has been developed, through fundamental analysis and computer modeling, that has higher photo-thermal conversion efficiency than surfaces using a homogeneous cermet layer or a graded film structure [31]. Solar radiation is effectively absorbed internally and by phase interference in double-cermet solar coatings. Further, it is easier to deposit the double-cermet selective coating than graded-cermet layer selective surfaces. The typical double-cermet layer film structure from surface to substrate consists of the following (Figure 6): an AR layer that enhances solar absorption; an absorbing layer composed of two homogenous cermet layers, a lowmetal-volume fraction (LMVF) cermet layer on a high-metal-volume fraction (HMVF) cermet layer; and a metallic infrared reflector layer to reduce substrate emittance [31].

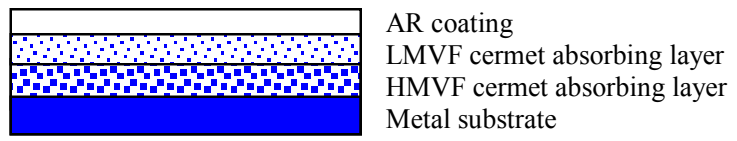

Figure 6. Schematic design of double-cermet film structure.

\section{e) Surface texturing}

Surface texturing is a common technique to obtain spectral selectivity by the optical trapping of solar energy. Properly textured surfaces appear rough and absorb solar energy while appearing highly reflective and mirror-like to thermal energy. The emittance can be adjusted (higher or lower) by modifying the microstructure (microcrystallites) of the coatings with ion-beam treatments [32]. Single-material surfaces can exhibit selective properties if they have the proper roughness, because the selective properties depend on the ratios of mean height deviations and the autocorrelation distance to the wavelength [33]. Properly orienting the textured material can improve the absorption and emissivity of a spectrally selective material. For example, in flat-plate collectors, straight trapezoidal grooves, with the grooves orientated for maximum efficiency (NW to SE), improve the characteristics of a gray absorber plate comparable to that of a flat-plate selective absorber plate [34]. In concentrating applications, to improve the optical properties, the orientation of any grooves in the substrate should be considered.

Needle-like, dendrite, or porous microstructures on the same scale as the wavelength of the incident radiation exhibit both wavelength and directional selectivity. This geometrical selectivity is not very sensitive however to the severe environmental effects (i.e., oxidation, thermal shocks) that has a catastrophic influence on the lifetime of conventional multilayer selective coatings [12]. The surface of the microstructure must be protected from damage caused by surface contact or abrasion. Selection of a material having a high intrinsic absorption coefficient can further optimize the absorptance. Methods to prepare textured microstructures include the following [12]: 1) Unidirectional 
solidification of eutectic alloys - enables formation of a porous, rod-like, or lamellar micromorphology depending on the type of eutectic and solidification parameters (e.g., $\mathrm{Al}_{3} \mathrm{Ni}$ fibers in Al-matrix from Al-Ni eutectic, $\mathrm{Mg}_{2} \mathrm{Ca}$ and $\mathrm{Mg}$ in $\mathrm{Mg}$-Ca eutectic, $\mathrm{Ni}, \mathrm{Cr}-$ $\mathrm{TaC}$ eutectic, Ni-Ta-Cr-Mn alloy). 2) Lithography with X-rays-a mask with a desired microstructure is copied using an X-ray-sensitive resist. 3) Ion-exchange reactions between metals - isothermal transport occurs between two metals where the difference in the work function $\left(\Delta \mathrm{E}_{\mathrm{w}}\right)$ is $>0.2 \mathrm{eV}$ (e.g., $\mathrm{Cu}-\mathrm{Ni}$ alloy). 4) Vapor-liquid-solid (VLS) mechanism - the controlled growth of whiskers on substrates from the liquid alloy zone at the interface (e.g., Si, Ge, III-V whiskers). 5) Vapor deposition-the condensation of a metal or compound from the gas phase onto a substrate by CVD or PVD (e.g., Ni- $\mathrm{Al}_{2} \mathrm{O}_{3}$, $\mathrm{Ni}$. 6) Oxidation of metals at high temperature - the growth of whiskers on metals by the oxidation process in air or $\mathrm{O}_{2}$ at high temperature $\left(400^{\circ}-850^{\circ} \mathrm{C}\right.$ ) (e.g., $\mathrm{Fe}_{2} \mathrm{O}_{3}-\mathrm{Fe}$, steel; $\mathrm{CuO}-\mathrm{Cu}$, phosphor bronze; $\mathrm{ZnO}-\mathrm{Zn}$, brass; W; Ni; Mo).

Chemically etching a tin-doped, $\mathrm{In}_{2} \mathrm{O}_{3}$ film to form a transparent microgrid with photolithography gives holes of about $2.5 \mu \mathrm{m}$ [35]. Reactive-sputter or ion etching with fluorocarbon gases (i.e., $\mathrm{CF}_{4}, \mathrm{CH}_{3}$ ), which is primarily a chemical process because the highly reactive species produced on the substrate, has been used with photolithography to produce square-wave gratings with micron and submicron periodicities [36]. Additionally, a vapor-phase transport process using catalyzed epitaxial crystal growth has recently synthesized high-density arrays of nanowires (e.g., ZnO-Ag) that are hexagonal in cross section and have diameters between 70 and $100 \mathrm{~nm}$ [37]. These techniques could be useful in texturing selective surfaces.

\section{f) Selectively solar-transmitting coating on a blackbody-like absorber}

A selectively solar-transmitting coating on a blackbody-like absorber is the last concept. The selective solar-transmitting coating can be a highly doped semiconductor (e.g., $\mathrm{SnO}_{2}: \mathrm{F}, \mathrm{SnO}_{2}: \mathrm{Sb}, \mathrm{In}_{2} \mathrm{SO}_{3}: \mathrm{Sn}$, and $\mathrm{ZnO}: \mathrm{Al}$ ) over an absorber with a proven longterm durability. Some low-temperature flat-plate collectors have used black enamel as the absorber material [38]. Highly doped semiconductors may be useful with hightemperature black absorber materials.

\section{Temperature Range of Absorber Materials}

To identify potential high temperature absorbers we have reviewed the literature for medium- to high-temperature absorber coatings, and the different types of selective surfaces are grouped according to increasing thermal stability. For CSP applications, the spectrally selective surface should be thermally stable above $400^{\circ} \mathrm{C}$, ideally in air, and have a solar absorptance greater than 0.95 and a thermal emittance below 0.15 at $400^{\circ} \mathrm{C}$. The applicability of the absorber coating for CSP applications is stated. The midtemperature absorber coatings are summarized in Table 1 and the high-temperature absorber coatings are summarized in Table 2 . Results are typically shown as a selectivity ratio of $\alpha / \varepsilon$, where the emittance is usually reported at $100^{\circ} \mathrm{C}\left[\alpha / \varepsilon\left(100^{\circ} \mathrm{C}\right)\right]$. In practice, emittance measurements made by the Gier-Dunkle instrument are measured at room 
temperature and a filter is used to simulate a $100^{\circ} \mathrm{C}$ measurement, i.e., by weighting the measurement by a $100^{\circ} \mathrm{C}$ blackbody curve. However, emittance can be measured (and is cited) at different temperatures. Emittance temperatures cited for $100^{\circ} \mathrm{C}$ or less are more indicative of the temperature capability of the instrument used to measure emittance, rather than the absorber's thermal stability. Emittance values are cited for $100^{\circ} \mathrm{C}$ in Table 1 and Table 2 unless otherwise indicated by a number in parenthesis. High temperature emittance values are differentiated between calculated or measured emittance, e.g., $\varepsilon_{\mathrm{C}}\left(400^{\circ} \mathrm{C}\right)$ or $\varepsilon_{\mathrm{M}}\left(400^{\circ} \mathrm{C}\right)$. 
Table 1. Mid-Temperature Selective Surfaces

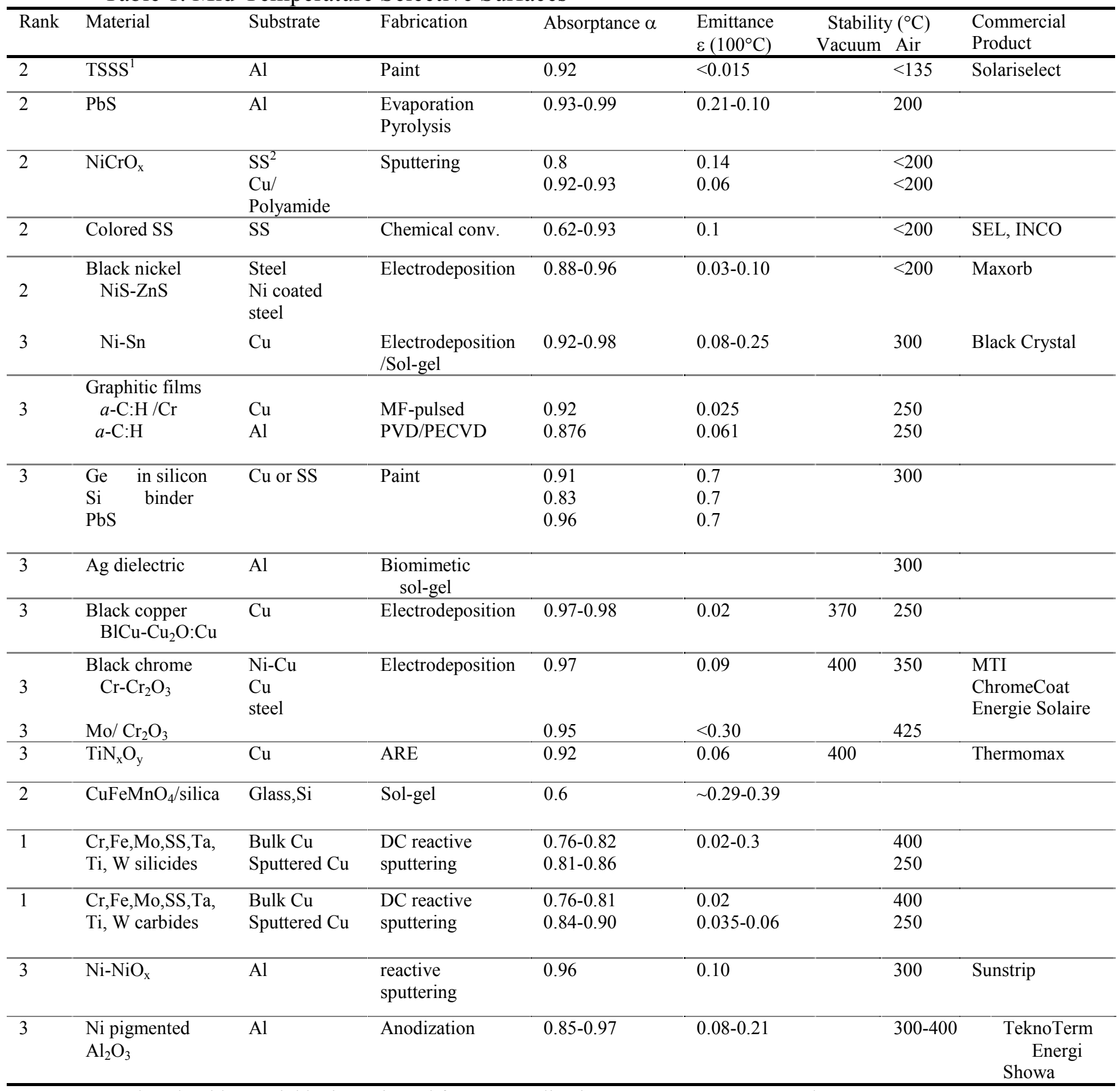

Rank $=$ Should material be investigated for CSP applications $1=$ Yes, $2=$ No, $3=$ Maybe

$\mathrm{TSSS}^{1}=$ Thickness-sensitive spectrally selective

$\mathrm{SS}^{2}=$ stainless steel 
Table 2. High-Temperature Selective Surfaces

\begin{tabular}{|c|c|c|c|c|c|c|c|c|}
\hline Rank & Material & Substrate & Fabrication & $\begin{array}{l}\text { Absorptance } \\
\alpha\end{array}$ & $\begin{array}{l}\text { Emittance } \\
\varepsilon\left(100^{\circ} \mathrm{C}\right)\end{array}$ & $\begin{array}{l}\text { Stability }\left({ }^{\circ} \mathrm{C}\right) \\
\text { Vacuum }\end{array}$ & Air & $\begin{array}{l}\text { Commercial } \\
\text { Product }\end{array}$ \\
\hline 2 & $\begin{array}{r}\mathrm{Ni}-\mathrm{Al}_{2} \mathrm{O}_{3} \\
\mathrm{SiO}_{2} \mathrm{AR}\end{array}$ & $\begin{array}{l}\text { Mo-Ni- } \\
\text { SS }\end{array}$ & RF sputtering & 0.94 & 0.07 & 500 & $350-400$ & \\
\hline 2 & $\mathrm{Co}-\mathrm{Al}_{2} \mathrm{O}_{3}$ & & & 0.94 & 0.04 & & & \\
\hline 3 & Mo- $\mathrm{Al}_{2} \mathrm{O}_{3}$ & $\mathrm{Ni}$ or $\mathrm{Al}$ & RF sputtering & 0.96 & $0.16(350)$ & $350-500$ & & Solel \\
\hline 1 & $\begin{array}{l}\text { W- } \mathrm{Al}_{2} \mathrm{O}_{3} \\
\text { W- } \mathrm{Al}_{2} \mathrm{O}_{3}\end{array}$ & Steel & $\begin{array}{l}\text { RF sputtering } \\
\text { CVD }\end{array}$ & $\begin{array}{l}0.97-0.98 \\
0.85\end{array}$ & $\begin{array}{l}0.1-0.07(400) \\
0.04\end{array}$ & 500 & & Solel \\
\hline $\begin{array}{l}1 \\
1\end{array}$ & $\begin{array}{l}\text { Pt- } \mathrm{Al}_{2} \mathrm{O}_{3} \\
\mathrm{Al}_{2} \mathrm{O}_{3}-\mathrm{Pt}-\mathrm{Al}_{2} \mathrm{O}_{3}\end{array}$ & $\mathrm{Cu}$ & RF sputtering & $0.90-0.98$ & 0.08 & & $\begin{array}{l}600 \\
600\end{array}$ & \\
\hline $\begin{array}{l}1 \\
2 \\
3 \\
1\end{array}$ & $\begin{array}{l}\text { Double } \\
\text { Mo- } \mathrm{Al}_{2} \mathrm{O}_{3} \\
\text { SS-AlN } \\
\text { Mo-AlN } \\
\text { W-AlN }\end{array}$ & $\mathrm{Cu}$ & DC Sputtering & $\begin{array}{l}0.96 \\
0.95 \\
0.92-0.94\end{array}$ & $\begin{array}{l}0.06\left(350_{\mathrm{C}}\right) \\
0.10\left(350_{\mathrm{C}}\right) \\
0.08-0.10\left(350_{\mathrm{C}}{ }^{\prime}\right.\end{array}$ & $\begin{array}{l}500 \\
350-500 \\
500 \\
500\end{array}$ & & TurboSun \\
\hline $\begin{array}{l}1 \\
1\end{array}$ & $\begin{array}{l}\text { Quasicrystals } \\
\text { multilayer } \\
\text { cermet }\end{array}$ & $\mathrm{Cu}, \mathrm{Si}$ & & $\begin{array}{l}0.90 \\
0.86-0.92\end{array}$ & $\begin{array}{l}0.025 \\
0.031-0.05\end{array}$ & $\begin{array}{l}500 \\
550\end{array}$ & 400 & \\
\hline 3 & $\mathrm{Si}_{3} \mathrm{~N}_{4} / \mathrm{Si}-\mathrm{Ge} / \mathrm{Ag}$ & $\mathrm{SS}, \mathrm{Al}$ & CVD & 0.890 & $\begin{array}{l}0.0389(300) \\
0.0545(500)\end{array}$ & & $650(\mathrm{He})$ & \\
\hline 1 & $\begin{array}{l}\mathrm{Ni}: \mathrm{SiO}_{2} \\
\mathrm{Cr}: \mathrm{SiO}\end{array}$ & $\mathrm{Al}, \mathrm{Cu}$ & $\begin{array}{l}\text { Reactive DC } \\
\text { sputtering }\end{array}$ & $0.90-0.96$ & $0.03-0.14$ & & $\begin{array}{l}400-800 \\
(\mathrm{Ar})\end{array}$ & \\
\hline 3 & Al-AlN ${ }_{x}-A 1 N$ & $\mathrm{SS}$ & Reactive DC & 0.97 & 0.10 & 500 & & \\
\hline 2 & $\mathrm{CuO}$ & $\mathrm{Cu}, \mathrm{SS}$ & Electroplating & 0.91 & 0.18 & & $<400$ & \\
\hline 1 & $\begin{array}{l}\mathrm{Ag} / \mathrm{CuO} / \mathrm{Rh}_{2} \mathrm{O}_{3} / \\
\mathrm{CeO}_{2} / /\end{array}$ & $\mathrm{SS}$ & $\begin{array}{l}\text { Organo-metallic } \\
\text { spray }\end{array}$ & 0.9 & 0.1 & 700 & 500 & \\
\hline 1 & $\begin{array}{r}\mathrm{CeO}_{2} / / \mathrm{Ag} / \mathrm{Pt} / \mathrm{CuO} / \\
\mathrm{Rh} / \mathrm{Rh}_{2} \mathrm{O}_{3} / / \mathrm{Ag} / \mathrm{Pt}\end{array}$ & & & $0.86-0.88$ & 0.1 & 775 & 550 & \\
\hline 1 & $\begin{array}{c}\mathrm{CeO} 2 / / \mathrm{CuO} / \mathrm{CoO} \\
\mathrm{Mn}_{2} \mathrm{O}_{3} / / \mathrm{Pt}\end{array}$ & & & $0.88-0.92$ & $0.06-0.12$ & 700 & 500 & \\
\hline $\begin{array}{l}1 \\
3\end{array}$ & $\begin{array}{l}\text { Black cobalt } \\
\mathrm{Co}_{3} \mathrm{O}_{4} / \mathrm{Co} \\
\mathrm{Ni}^{-} \mathrm{Co}_{3} \mathrm{O}_{4} / \mathrm{Co}\end{array}$ & & & $\begin{array}{l}0.96-0.92 \\
0.95\end{array}$ & $\begin{array}{l}0.71-0.017 \\
0.10\end{array}$ & & $400-650$ & \\
\hline 1 & $\begin{array}{l}\text { Black moly } \\
\quad \mathrm{Mo-}^{-\mathrm{MoO}_{2}}\end{array}$ & & CVD & 0.94 & $0.30\left(500_{C}\right)$ & 500 & 350 & \\
\hline 1 & $\begin{array}{l}\text { Black Tungsten } \\
\mathrm{W}-\mathrm{WO}_{\mathrm{x}}\end{array}$ & & CVD & 0.83 & 0.15 & 800 & & \\
\hline $\begin{array}{l}1 \\
3\end{array}$ & $\begin{array}{l}\mathrm{Au} / \mathrm{TiO}_{2} \\
\mathrm{Au} / \mathrm{MgO}\end{array}$ & $\begin{array}{l}\mathrm{SS} \\
\mathrm{Mo} / \mathrm{SS}\end{array}$ & $\begin{array}{l}\text { Sol-gel } \\
\text { RF Sputtering }\end{array}$ & $\begin{array}{l}0.85 \\
0.90-0.93\end{array}$ & $\begin{array}{l}0.01\left(400_{\mathrm{C}}\right) \\
0.04-0.1\end{array}$ & $>500$ & 400 & \\
\hline $\begin{array}{l}3 \\
3 \\
1\end{array}$ & $\begin{array}{l}\mathrm{ZrC}_{\mathrm{x}} \mathrm{N}_{\mathrm{y}} \\
\mathrm{Al}_{2} \mathrm{O}_{3} / \mathrm{ZrC}_{\mathrm{x}} \mathrm{N}_{\mathrm{y}} / \mathrm{Ag} \\
\mathrm{ZrO}_{\mathrm{x}} / \mathrm{ZrC}_{\mathrm{x}} / \mathrm{Zr}\end{array}$ & $\begin{array}{l}\mathrm{Al} \\
\mathrm{SS}\end{array}$ & & $\begin{array}{l}0.85 \\
0.91 \\
0.90\end{array}$ & $\begin{array}{ll}0.074 & \left(325_{C}\right) \\
0.05 & \left(325_{C}\right) \\
0.05(20)\end{array}$ & $\begin{array}{l}600 \\
700 \\
700\end{array}$ & $\begin{array}{l}125 \\
175\end{array}$ & \\
\hline $\begin{array}{l}3 \\
1\end{array}$ & $\begin{array}{l}\mathrm{TiN} \\
\mathrm{Ti}_{1-\mathrm{x}} \mathrm{Al}_{\mathrm{x}} \mathrm{N}\end{array}$ & $\mathrm{Cu}, \mathrm{Al}$ & $\begin{array}{l}\text { DC reactive } \\
\text { sputtering }\end{array}$ & 0.80 & $0.14-0.40$ & & $\begin{array}{l}500 \\
750-900\end{array}$ & \\
\hline 3 & $\mathrm{M}_{\mathrm{b}} \mathrm{O}_{\mathrm{c}}+\mathrm{M}^{\prime} \mathrm{Fe}_{2} \mathrm{O}_{4}$ & $\begin{array}{l}\text { Ni-Mo } \\
\text { alloy }\end{array}$ & $\begin{array}{l}\text { Painting } \\
\text { Arc plasma }\end{array}$ & $>0.90$ & $>0.45$ & & $\begin{array}{l}700 \\
1060\end{array}$ & \\
\hline 1 & $\begin{array}{l}\mathrm{VB}_{2}, \mathrm{NbB}_{2}, \mathrm{TaB}_{2}, \\
\mathrm{TiB}_{2}, \mathrm{ZrB}_{2}, \mathrm{LaB}_{6} \\
\mathrm{WSi}_{2}, \mathrm{TiSi}_{2} \\
\mathrm{Si}_{3} \mathrm{~N}_{4} \mathrm{AR}-\mathrm{ZrB}_{2}\end{array}$ & Glass & $\begin{array}{l}\text { DC reactive } \\
\text { sputtering } \\
\text { CVD }\end{array}$ & $0.88-0.93$ & 0.08 to 0.10 & $\begin{array}{l}2300- \\
3040 \\
(\mathrm{MP})\end{array}$ & 500 & \\
\hline 3 & Masterbeads $^{(\mathbb{R})}$ "paint' & & & 0.93 & & & $<1000$ & \\
\hline 2 & C-Textured $\mathrm{Cu}$ & $\mathrm{Cu}$ & & 0.9 & $0.04(20)$ & 400 & & \\
\hline 2 & Textured Ni & $\mathrm{Ni}$ & & $0.92 \pm 0.2$ & $0.09 \pm 0.02$ & & $<300$ & \\
\hline 1 & Textured SS & & & $0.93 \pm 0.02$ & $0.22 \pm 0.02$ & $>440$ & & \\
\hline 3 & Textured $\mathrm{Cr}$ & SS & & $0.80-0.90$ & $0.10-0.30$ & & $<500$ & \\
\hline 1 & $\mathrm{~W}$ whiskers & $\mathrm{Cr}$ & & 0.98 & $>0.26$ & 550 & & \\
\hline 1 & $\mathrm{Mo}, \mathrm{Rh}, \mathrm{Pt}, \mathrm{W}, \mathrm{HfC}, \mathrm{Au}$ & & & & & & $>600$ & \\
\hline 1 & $\mathrm{NiO}_{\mathrm{x}}, \mathrm{CoO}_{\mathrm{x}}$ & & & & & & 800 & \\
\hline
\end{tabular}




\subsection{Mid-temperature selective surfaces $\left(100^{\circ} \mathrm{C}<T<400^{\circ} \mathrm{C}\right)$}

\section{1.a. Semiconductor-metal tandems}

The semiconductor lead sulfide $(\mathrm{PbS})$ has been prepared on aluminum by various processes. The $\mathrm{PbS}$ surface is stable at room temperature and has good adhesion. The optimal thickness of $\mathrm{PbS}$ to achieve destructive interference at the wavelength of solar maximum gives $\alpha / \varepsilon\left(100^{\circ} \mathrm{C}\right)=0.93-0.99 / 0.21-0.038$ [39]. Tests showed that evaporated $\mathrm{PbS}$ on aluminum was stable in vacuum over a wide range of temperatures, including the operating temperature of $300^{\circ} \mathrm{C}$ [40]. The use of porous $\mathrm{PbS}$ and AR coatings can further reduce the reflectance. With stability between room-temperature and $300^{\circ} \mathrm{C}, \mathrm{PbS}$ will not be useful for CSP applications.

\section{1.b Metal-dielectric composite coatings}

\section{1.b.1 Chemical conversion}

4.1.b.1.1. Stainless steel is colored by the formation of a thin film when immersed in hot solutions of chromic and sulfuric acid. Blue has the highest selectivity $\left[\alpha / \varepsilon\left(100^{\circ} \mathrm{C}\right)=0.90 / 0.10\right]$ for chemically converted blue, golden, red, green, and gray stainless steel [41]. Even with the addition of a protective layer of Mylar, lacquer, $\mathrm{Cr}_{2} \mathrm{O}_{3}$, $\mathrm{Si}_{3} \mathrm{~N}_{4}$, and, glass, the solar absorptance degrades after exposure to $200^{\circ} \mathrm{C}$. Black steel produced by similar methods with $\alpha / \varepsilon\left(100^{\circ} \mathrm{C}\right)=0.90 / 0.23$ is stable for $7000 \mathrm{~h}$ at $200^{\circ} \mathrm{C}$ [42]. Because of the low-temperature stability, the colored or blackened steels will not be useful for CSP applications.

4.1.b.1.2. Black nickel (NiS-ZnS) is formed by the electrodeposition of nickel on a metal substrate in the presence of zinc and sulfides. Different groups have modified the electrodeposition bath and process to produce coatings where $\alpha / \varepsilon\left(100^{\circ} \mathrm{C}\right)=0.88$ 0.96/0.03-0.10 for $\mathrm{T}<200^{\circ} \mathrm{C}$ [43-46]. Black nickel degrades in humid environments and on exposure to temperatures of $200^{\circ} \mathrm{C}$ and is therefore not applicable for CSP applications [47]. Mason and Brendel reported that by incorporating topological microroughness into Maxorb, they enhanced the solar absorptance $\alpha / \varepsilon\left(100^{\circ} \mathrm{C}\right)=0.97 / 0.08$ of their black nickel [48]. The Maxorb passed testing under the following conditions: 7 days at $50^{\circ} \mathrm{C}$ and $90 \%$ relative humidity, and 200 thermal cycles between $-50^{\circ} \mathrm{C}$ and $100^{\circ} \mathrm{C}$. Black Crystal ${ }^{\mathrm{TM}}$ or Black Forest ${ }^{\mathrm{TM}}$, are non-oxidized metallic Ni-Sn alloy solarselective coatings on a copper substrate [49]. Nearly all other black nickel solar-selective coatings contain oxides of nickel. Its high solar-absorbing characteristics, $\alpha / \varepsilon\left(100^{\circ} \mathrm{C}\right)=0.92-0.98 / 0.08-0.25$ with a thermal stability up to $300^{\circ} \mathrm{C}$, are a result of the micro-surface light-trapping morphology. This coating is produced by combining two processes: the electrodeposition of the crystallographic metallic alloy and applying a solgel overcoat. It has been developed jointly by Energy Laboratories, Inc. (ELI) in Jacksonville, Florida, and Sandia National Laboratories. This work is being done under a cooperative research and development agreement (CRADA) and is funded by both the U.S. Department of Energy (DOE) CSP and Solar Buildings Programs. These processes occur in solution, and the problem with materials made in solution is that they contain water. Under solar concentrating temperatures, the materials oxidize when they are 
exposed to air. In evacuated tube-type systems, the materials made in solution outgas water and gases into the evacuated tubes, causing a loss of vacuum, which allows heat transfer loss [50]. Therefore, black nickel is not appropriate for deployment in evacuated tube-type systems.

4.1.b.1.3. Textured black copper $\left(\mathrm{BlCu}-\mathrm{Cu}_{2} \mathrm{O}: \mathrm{Cu}\right)$ selective surfaces produced by chemically treating copper [the copper substrate is placed in a $\mathrm{HNO}_{3}$ bath, followed by chemical oxidization in alkaline bath $\left.\left(\mathrm{K}_{2} \mathrm{~S}_{2} \mathrm{O}_{8}\right)\right]$, have a $\alpha / \varepsilon\left(100^{\circ} \mathrm{C}\right)=0.97-0.98 / 0.02$ [51]. Black copper is thermally stable at $\mathrm{T}<250^{\circ} \mathrm{C}$ under ambient conditions and $<370^{\circ} \mathrm{C}$ in vacuum [51]. Black copper has good ultraviolet (UV), humidity, and environmental stability for $600 \mathrm{~h}$ in air up to $\sim 230^{\circ}-250^{\circ} \mathrm{C}$ [52]. Texturing of the selective surface increased the solar absorptance and emittance, and increased the thermal stability in vacuum only (up to $\mathrm{T}<350^{\circ} \mathrm{C}$ ). Increasing the surface area of the emitting surface with ion-beam treatment or seeding could optimize the emittance [32]. However, the temperature stability range of these materials is below the minimum $400^{\circ} \mathrm{C}$ in air needed for the CSP program and is not likely to be of use for the CSP program.

4.1.b.1.4. Black chrome $\left(\mathrm{Cr}-\mathrm{Cr}_{2} \mathrm{O}_{3}\right)$, an electrodeposited $\mathrm{Cr}-\mathrm{Cr}_{2} \mathrm{O}_{3}$ cermet on $\mathrm{Ni}$, $\mathrm{Fe}, \mathrm{Cu}$, stainless-steel substrates, has an $\alpha / \varepsilon\left(100^{\circ} \mathrm{C}\right)=0.97 / 0.09$ for temperatures $<300^{\circ} \mathrm{C}$ [44, 53-59]. Black chrome is commercially produced by MTI on Ni-plated $\mathrm{Cu}$ in the United States, by ChromeCoat of Denmark on copper, and on stainless-steel by Energie Solaire in Switzerland [5]. All three materials have passed the flat-plate IEA Task X service lifetime and performance criterion. Researchers have found that a layer of $\mathrm{Ni}$ between the substrate and black chrome coating gives better stability up to $400^{\circ} \mathrm{C}$ [60]. Oxidation of the metallic $\mathrm{Cr}$ crystallite and densification of the crystallites primarily cause the degradation of the selective coating [61]. At high temperatures, Ni diffusion from the substrate contributes to optical degradation [62]. When the $\mathrm{Cr}^{+3}$ concentration in the standard black-chrome baths was reduced, laboratory samples were produced that are stable in air for $3908 \mathrm{~h}$ at $350^{\circ} \mathrm{C}$ and for $670 \mathrm{~h}$ at $400^{\circ} \mathrm{C}$ [63]. The reflectance after exposure at $350^{\circ} \mathrm{C}$ in air is approximately equivalent to that after exposure at $400^{\circ} \mathrm{C}$ in vacuum [64]. Heat treatments established that black chrome failed optically between $500^{\circ}-600^{\circ} \mathrm{C}$ after $1 \mathrm{~h}$ in both air and vacuum and the coating failed mechanically by peeling after $600^{\circ} \mathrm{C}$ in air [65]. Improvements in performance are possible with the addition of an AR topcoat and if a metallic layer is used at the interface to act as the IR reflector instead of the $\mathrm{Cu}$ or $\mathrm{Al}$ substrates, because the $\mathrm{Cu}$ and $\mathrm{Al}$ diffuse from the substrate at the higher CSP operating temperatures. Black chrome solar selective films can be modified by admixing molybdenum, up to $20 \%$ of the chromium content [66]. Absorptance is stable for an $\mathrm{Mo} / \mathrm{Cr}$ ratio of $0.6 \%$ at a value of 0.95 for $146 \mathrm{~h}$ up to $425^{\circ} \mathrm{C}$ in air [66]. These processes are made in solution and can outgas in evacuated tube-type systems causing a loss of vacuum and heat transfer loss.

4.1.b.1.5. Stable nickel (Ni)-pigmented alumina $\left(\mathrm{Al}_{2} \mathrm{O}_{3}\right)$ cermet selective surface coatings on aluminum substrates intended for flat-plate collectors are widely reported with $\alpha / \varepsilon\left(100^{\circ} \mathrm{C}\right)=0.85-0.97 / 0.08-0.21$ for $300^{\circ} \mathrm{C}<\mathrm{T}<500^{\circ} \mathrm{C}$, and are commercially produced by TeknoTerm Energi in Sweden and Showa in Japan [67-78]. They are made by the phosphoric anodic anodization of aluminum whose pores are impregnated with $\mathrm{Ni}$, but other metals such as V, Cr, Co, Cu, Mo, Ag, Si, and W can be used (Figure 4a) [69]. A cobalt-pigmented $\mathrm{Al}_{2} \mathrm{O}_{3}$ cermet is stable up to $400^{\circ} \mathrm{C}$ in air and has 
$\alpha / \varepsilon\left(100^{\circ} \mathrm{C}\right)=0.92 / 0.28$, although its emittance is higher than the preferred 0.15 maximum [74]. However, anodized $\mathrm{Si}_{-} \mathrm{Al}_{2} \mathrm{O}_{3}$ cermets are not a candidate for selective solar absorbers because there is no thickness range having high solar absorptance, while also having low thermal emittance [75,76]. The TeknoTerm rolled-aluminum substrate has pronounced grooves; the grooves are apparent in the front surface of the coating. The thickness of the plain alumina layer is crucial to the angular solar absorptance, which is not the case for the nickel-pigmented base layer [77,78]. Many kinetic studies have been performed on the nickel rods remaining after the alumina is removed by etching to determine the optimum rod size, but the results have not been incorporated into the commercial products [26-28, 79-82]. The lifetime of the selective surface is shortened by exposure to high temperature, humidity, and atmospheric pollution such as sulfur dioxide. This selective coating is also sensitive to abrasion. The addition of a mechanically stable transparent coating reduces the degradation due to abrasion, high temperature, weathering, and chemical attacks. The addition of pyrolytically deposited fluorine- or antimony-doped tin oxide $\left(\mathrm{SnO}_{2}: \mathrm{F}\right.$ or $\left.\mathrm{SnO}_{2}: \mathrm{Sb}\right)$ dipped coatings has improved the performance. $\mathrm{SiO}_{2} / \mathrm{SnO}_{2}: \mathrm{F} / \mathrm{Ni}-\mathrm{Al}_{2} \mathrm{O}_{3}$ samples have a $\alpha=0.94$ and $\varepsilon=0.15$ and show no degradation in the optical properties after temperatures up to $300^{\circ} \mathrm{C}$ for $24 \mathrm{~h}$ [83]. $\mathrm{SnO}_{2}: \mathrm{Sb} / \mathrm{Ni}-\mathrm{Al}_{2} \mathrm{O}_{3}$ samples have a $\alpha=0.92$ and $\varepsilon=0.21$ and are resistant to curing temperatures up $450^{\circ} \mathrm{C}$ for $2 \mathrm{~h}$ [84]. A nickel-pigmented aluminum oxide with a doublelayer structure has an enhanced high-angle solar absorptance because of thin-film interference effects and has been found to perform better than the graded-index nickel/nickel oxide coating [85]. Although kinetic studies have been performed up to $500^{\circ} \mathrm{C}$ for 1 to $500 \mathrm{~h}$ that show nickel particle stability, because of the aluminum substrate and Al diffusion at the higher CSP operating temperatures, the nickelpigmented alumina is unlikely to be suitable for CSP applications.

\section{1.b.2. Paint coatings}

4.1.b.2.1. Thickness-sensitive spectrally selective (TSSS) paint coatings are lowtemperature alternatives for selective coatings. Paint coatings called Solariselect ${ }^{\circledR}$ are spectrally sensitive $\alpha / \varepsilon\left(100^{\circ} \mathrm{C}\right)=0.92 / 0.38$ when applied $2-3 \mu \mathrm{m}$ thick to aluminum substrates [86]. Two commercial products for low-temperature flat-plate collectors have recently been introduced, Solarect- $Z^{\mathrm{TM}}$ developed at the National Institute of Chemistry in Ljubljana, Slovenia and SolkoteHI/SORB-II ${ }^{\mathrm{TM}}$ paint sold by SOLEC (Solar Energy Corporation), USA. Various black paints suitable for coil coating applications on aluminum with different pigment-to-volume concentration (PVC) ratios (27\%-39\%) were made from phenoxy resin and $\mathrm{FeMnCuO}_{\mathrm{x}}$ pigment. Optimization of the optical properties $\left[\alpha / \varepsilon\left(100^{\circ} \mathrm{C}\right)=>0.92 /<0.015\right]$ of the TSSS paint coating was obtained by adding fumed silica and a silane coupling agent in a PVC ratio of about 35\% [87]. The paint is stable up to $135^{\circ} \mathrm{C}$, but the paint thins and begins to outgas at $220^{\circ} \mathrm{C}$ [88]. Different (more expensive) paint formulations may improve the paint stability [88]. Without substantial improvements in the paint stability, the TSSS paint coatings will not be applicable for concentrating applications.

4.1.b.2.2. A semiconductor-pigmented paint that consists of small particles of Ge, $\mathrm{Si}$, or $\mathrm{PbS}$ mixed with a high-temperature silicone binder applied to polished copper or stainless-steel substrates have been tried as a low-cost solar absorber. The silicone binder 
was found to be stable to $350^{\circ} \mathrm{C}$ for at least $12 \mathrm{~h}$ in air, and has been used for emissive paints to $>1000^{\circ} \mathrm{C}$ [89]. Although at normal angle of incidence, the solar absorptance of all the paints was high $[\alpha(\mathrm{PbS})=0.96, \alpha(\mathrm{Ge})=0.91, \alpha(\mathrm{Si})=0.83]$, the total hemispherical emittance of the paints was higher than 0.70 from room temperature to $300^{\circ} \mathrm{C}$ because of the emittance of the silicone binder [90]. These paints are not suitable as a solar-selective coating unless the amount of silicone binder can be reduced or a high-temperature, lowemittance binder can be found to replace the silicone binder.

4.1.b.2.3. Black-colored $\mathrm{CuFeMnO}_{4}$ spinel powders and films were prepared using the sol-gel process from $\mathrm{Mn}$-acetate and $\mathrm{Fe}$ - and $\mathrm{Cu}$-chloride precursors. For $\mathrm{CuFeMnO}_{4} /$ silica films, 3-aminopropyl-triethoxysilane (3-APTES) and tetraethoxysilane (TEOS) were used in 1:1 molar (Mn:Cu:Fe):silica proportion [91]. The films were deposited by dip-coating and thermally cured at $500^{\circ} \mathrm{C}$. The resulting $(\mathrm{Mn}: \mathrm{Cu}: \mathrm{Fe}) / 3-$ APTES coatings had a composite structure consisting of the $\mathrm{Cu}_{1.4} \mathrm{Mn}_{1.64}$ spinel and the amorphous $\mathrm{SiO}_{2}$ lower layer [91]. The $\mathrm{Fe}$ concentration varied from lower $(\mathrm{Mn}: \mathrm{Fe}=2.6: 1)$ to higher $\mathrm{Mn} / \mathrm{Fe}$ ratios composition $(\mathrm{Mn}: \mathrm{Fe}=1.5: 1)$. The composition of the upper grains corresponds to the nearly stoichiometric ratio of $3: 3: 1$ of the $(\mathrm{Mn}: \mathrm{Cu}: \mathrm{Fe})$ precursors. The corresponding composite films had $\alpha / \varepsilon\left(100^{\circ} \mathrm{C}\right)=\sim 0.6 / \sim 0.29-0.39$, where the $\alpha$ is too low and the $\varepsilon$ is too high [91]. This is caused by differences in the film thickness. The absorbing layer of the spinel film $(200 \mathrm{~nm})$ was much thinner than the lower amorphous $\mathrm{SiO}_{2}$ layer $(800 \mathrm{~nm})$. Using TEOS and a different base catalyst $\left(\mathrm{NH}_{3}\right)_{\mathrm{aq}}$ increased the $\alpha(>0.93)$, but the thermal emittance values were too high because of the presence of large $\mathrm{SiO}_{2}$ spherical particles $(400-420 \mathrm{~nm})$ [91]. These films are not suitable as a solar-selective coating, but replacing the highly emitting $\mathrm{SiO}_{2}$ with an IRtransmitting (i.e. non-emitting) $\mathrm{ZrO}_{2}, \mathrm{TiO}_{2}$, or $\mathrm{CeO}_{2}$ layer should improve the performance of the absorbers and could make them suitable for CSP.

\section{1.b.3. Deposited Cermet}

4.1.b.3.1. Reactively sputtered $\mathrm{NiCrO}_{x}$ on stainless-steel substrates has near-zero reflectance at $0.8 \mu \mathrm{m}$ and a high reflectance in the infrared. The $\mathrm{NiCrO}_{\mathrm{x}}$ stainless-steel substrate has $\alpha / \varepsilon\left(60^{\circ} \mathrm{C}\right)=0.8 / 0.14$ [92]. A sputtered $\mathrm{Ni}-\mathrm{Cr}$ selective surface on copper deposited on polyamide has $\alpha / \varepsilon\left(60^{\circ} \mathrm{C}\right)=0.92-0.93 / 0.06$ and is stable for use under $200^{\circ} \mathrm{C}$ [93]. In general, constructions with organics will not have the desired thermal stabilities. $\mathrm{NiCrO}_{\mathrm{x}}$ is useful for low temperature applications, but is not useful for concentrating applications.

4.1.b.3.2. Selective coatings can be made with thick spray-coated graphitic films with $\alpha=0.80-0.90$ and $\varepsilon=0.5-0.6$ as diamond-like carbon (DLC), a glassy carbon, or as bulk graphite $[94,95]$. A durable amorphous hydrogenated carbon $(a-\mathrm{C}: \mathrm{H}) / \mathrm{Cr}$ on copper substrate has been manufactured on an industrial scale by medium-frequency (MF)pulsed plasma technology with a $\alpha / \varepsilon\left(100^{\circ} \mathrm{C}\right)=0.92 / 0.025$ and has passed the IEA Task X performance criterion for low-temperature applications [96]. Optical selective surfaces with tungsten-, chromium-, and titanium-containing $a-\mathrm{C}: \mathrm{H}$ films on aluminum substrates have been produced by combining PVD and plasma-enhanced chemical vapor deposition (PECVD) [97,98]. Even though the layer thickness and stoichiometry has not been optimized, experimental results are promising, with a $\alpha / \varepsilon\left(100^{\circ} \mathrm{C}\right)=0.876 / 0.061$ [98]. Accelerated aging studies at $220^{\circ} \mathrm{C}$ and $250^{\circ} \mathrm{C}$ in air pass the performance criterion, and 
the service lifetime is predicted to be more than 25 years for flat-plate collectors; however, the temperature stability of this material is too low for it to be applicable for CSP applications.

4.1.b.3.3. Silver dielectric composite films were prepared in a sol-gel type deposition by biomimetic techniques, where the bacterial strain Pseudomonas stutzeri $A G 259$ is used as a precursor $[99,100]$. The bacterial strain, which was originally isolated from a silver mine, accumulates silver at the cell wall. Thin films were deposited onto aluminum sheet substrates. The film was stabilized and its optical properties adjusted by heat treatments between $300^{\circ}-400^{\circ} \mathrm{C}$. The resulting coating was hard and resistant to mechanical scratching with a knife. The matrix material can be regarded as hydrogenated amorphous carbon $(\mathrm{a}-\mathrm{C}: \mathrm{H})$ doped with further organic cell constituents, mainly phosphorous, sulfur, calcium, potassium, and chlorine [101]. Bacterial cells incubated with $\mathrm{Au}^{3+}$ ions readily precipitate gold nanoparticles [102]. Bacillus subtilis 168 precipitate non-crystalline gold nanoparticles that can be transformed into crystalline octahedral gold containing sulfur and phosphorous [103]. An acid-loving fungus of the Vericillium species grown in chlorauric acid $\left(\mathrm{HAuCl}_{4}\right)$ can reduce the $\mathrm{AuCl}_{4}{ }^{-}$to 20 -nmdiameter gold nanoparticles within and on the surface of the fungal cells [103]. The shift from bacteria to fungi has the advantage of simpler processing and handling, significantly higher production rates, and the possibility of covering a large surface area. Biomimetic materials technology is in its infancy and is presently of conceptual interest, but does not hold much near-term practical promise. Significant work will be needed to optimize this technology before useful absorber materials can be produced.

4.1.b.3.4. Absorbers with $\operatorname{TiN}_{x} O_{y}$ cermet deposited by activated reactive evaporation (ARE) on copper substrates are suitable for applications above $200^{\circ} \mathrm{C}$ without concentration and have an emittance of 0.04 measured at $300^{\circ} \mathrm{C} . \mathrm{SiO}_{2} / \mathrm{TiN}_{\mathrm{x}} \mathrm{O}_{\mathrm{y}} / \mathrm{Cu}$ were found to have $\alpha / \varepsilon\left(100^{\circ} \mathrm{C}\right)=0.94 / 0.044$ and to be thermally stable under vacuum up to $400^{\circ} \mathrm{C}[104,105]$. These coatings are stable in high vacuum, but degrade (mainly the emittance) quickly when exposed to air, of even low partial pressure, at elevated temperatures [106]. After examination of the degradation mechanisms, improvements have been made in the $\alpha / \varepsilon\left(100^{\circ} \mathrm{C}\right)=0.94 / 0.08-0.12$ by replacing the $\mathrm{Cu}$ with $\mathrm{Al}$ and adding an $\mathrm{SiO}_{2}$ AR layer, but the construction still needs to be optimized [105]. Copper substrates generally imply flat-plate applications and copper is not suitable for hightemperature CSP applications. Copper oxidation is the final stage in four steps of degradation. First, the $\mathrm{TiN}_{\mathrm{x}} \mathrm{O}_{\mathrm{y}}$ film alone structurally and chemically changes to $\mathrm{TiN}$ and $\mathrm{TiO}$ without interacting with the substrate. Second, the TiN and TiO oxidize to form crystalline rutile $\mathrm{TiO}_{2}$ and then the copper becomes mobile and roughens the filmreflector interface. Third, a quasi-liquid film-substrate mixture rises through the pores formed in the interface region and oxidizes on the surface of the film. This destroys the selective properties and mechanical stability of the film. The final fourth step is the reconstruction of a chemically stable amorphous film of titanium oxides and crystalline copper oxides with 1- $\mu \mathrm{m}$ craters located at previous pore sites [106]. However, the formation of copper oxide is operative only at elevated temperatures; in the operational range of $350^{\circ} \mathrm{C}$, the outer surface is nitrogen rich, not oxygen rich, contrary to the previous literature, and $\mathrm{Ti}$ ions are progressively replaced by $\mathrm{Cu}$ diffusing from the substrate [107]. Thermomax ${ }^{\mathrm{TM}}$, a commercial $\mathrm{TiN}_{\mathrm{x}} \mathrm{O}_{\mathrm{y}}$ cermet on copper substrate product is produced by a German company called TiNOx. Thermomax has an 
$\alpha / \varepsilon\left(100^{\circ} \mathrm{C}\right)=0.92 / 0.06$ for temperatures up to $400^{\circ} \mathrm{C}$ in vacuum and a 30 -year lifetime [108]. Ion-assisted deposition (IAD) has also been used to form dense uniform $\mathrm{TiN}_{\mathrm{x}} \mathrm{O}_{\mathrm{y}}$ selective surfaces [109]. The performance of $\mathrm{TiN}_{\mathrm{x}} \mathrm{O}_{\mathrm{y}}$ cermets may be improved, with the addition of an AR topcoat and an IR metallic layer, instead of the $\mathrm{Cu}$ or Al substrates.

4.1.b.3.5. Selective surfaces from metal carbide and silicides are stable at high temperature because of their refractory nature and low vapor pressure. Chromium, iron, molybdenum, stainless steel, tantalum, titanium, tungsten silicides, and carbides were direct-current (DC) reactively sputtered on bulk and evaporated copper [110-112]. A solar absorptance of 0.76-0.82 and a thermal emittance of 0.02-0.3 were observed at room temperature for the silicides on bulk copper [111]. On sputtered copper, $\alpha$ increased to 0.81-0.86 because such copper coatings have lower film reflectance than the bulk copper substrates. Stainless-steel and titanium silicides had the best optical performance, with the highest $(\alpha=0.87$ and $\varepsilon=0.045)$ being stainless-steel silicide on evaporated Ni. Similarly, the carbides on bulk copper have $\alpha=0.76-0.81$ and $\varepsilon=0.02$, and on sputtered copper, $\alpha=0.84-0.90$ and $\varepsilon=0.035-0.06$ [111]. Molybdenum carbide on bulksputtered metal had the highest optical properties $(\alpha=0.90$ and $\varepsilon=0.035)$ [111]. Titanium carbide films were particularly unstable and their appearance changed when stored for a few days at room temperature [113]. However, bleeding nitrogen in during the first two minutes of sputtering improved the adhesion, friction, and wear properties of the titanium carbide [114]. Films with resistivities of about $0.1 \Omega \mathrm{cm}$ had the best properties for solar absorbers [113]. The films on bulk and sputtered copper substrates exhibit different aging effects. No deterioration was observed after $250 \mathrm{~h}$ at $250^{\circ} \mathrm{C}$ and $400^{\circ} \mathrm{C}$ in air for the films on bulk copper, whereas the films on sputtered copper began to deteriorate slightly at $250^{\circ} \mathrm{C}$. Solar absorptance can be increased by making a multilayer stack of the pure metal and metal carbide films. A solar absorptance of 0.89-0.93 and thermal emittance of 0.03-004 at room temperature was observed, but the stack is slightly less stable at elevated temperatures because of interdiffusion between the layers [112]. The silicides and carbides are of interest for CSP applications, especially if an AR layer is added to increase the $\alpha$ and the copper metallic layer is replaced with a more temperature-stable reflective layer to improve durability.

4.1.b.3.6. Commercially produced Sunstrip in Sweden is a graded $\mathrm{NiO}_{x}$ cermet layer produced by reactive magnetron sputtering with a $\mathrm{Ni}$ reflective layer and AR layer and has an $\alpha / \varepsilon\left(100^{\circ} \mathrm{C}\right)=0.96 / 0.10$ for low-temperature, none-concentrating applications [85]. This material has passed the IEA Task X service lifetime and performance criterion [115]. The nickel-nickel oxide absorber does not fulfill the conditions for an ideal gradedindex layer, but adjusting the metal content of the absorber coating and adding an AR coating gives acceptable optical properties [116]. The grooves in the substrate of the nickel/nickel oxide coated alumina are more apparent than for the nickel-pigmented anodized aluminum at angles of incidence greater than $40^{\circ}$; therefore, the orientation of the grooves should be considered $[68,76,77]$. The graded $\mathrm{NiO}_{\mathrm{x}}$ cermet is a cost-effective material for low-temperature flat-plate collectors, but its durability at high temperatures needs to be determined. It is unlikely to meet the needs for high-temperature CSP applications, because as has been demonstrated by other cermets, cermets with nickel have insufficient thermal stability. 


\subsection{High-temperature selective surfaces $\left(T>400^{\circ} \mathrm{C}\right)$}

\section{2.a. Semiconductor-metal tandems}

Silicon tandem absorbers with high-temperature stability have been made by CVD. The three-part optical system uses a reflective, absorber, and antireflection layer [117]. Silver is the reflective layer, because of its low thermal emittance, and silicon is the absorber. The stainless-steel substrate is coated with a thin $\mathrm{Cr}_{2} \mathrm{O}_{3}$ barrier coating to withstand thermal cycling stresses and to prevent diffusion between the silver and the substrate. Silver is deposited and overcoated with a thin layer of chrome oxide. Silver films agglomerate at temperatures of $300^{\circ} \mathrm{C}$ and above, but the addition of the chrome oxide overcoat stabilizes the silver up to temperatures of $825^{\circ} \mathrm{C}$ in a helium environment and prevents diffusion into the silicon absorber layer [118]. The silicon bulk absorber is deposited by silane pyrolysis at $640^{\circ} \mathrm{C}$, which is followed by an antireflection $\mathrm{Si}_{3} \mathrm{~N}_{4}$ coating. No degradation in the optical properties has been observed after exposure at $650^{\circ} \mathrm{C}$ in vacuum for $20 \mathrm{~h}$ and cycling 200 times from ambient to $500^{\circ} \mathrm{C}$ [119]. For this construction, the maximum theoretical solar absorptance at $427^{\circ} \mathrm{C}$ is $\alpha=0.91$, while $\varepsilon \leq$ 0.09 ; larger values of absorptance can be traded off against higher value of $\varepsilon$ [120]. Improvements have been suggested by adding a thin layer of germanium to increase the solar absorptance. The best performance has been calculated for $0.5-\mu \mathrm{m}$ Ge and $2.0-\mu \mathrm{m}$ Si with a $\mathrm{Si}_{3} \mathrm{~N}_{4} \mathrm{AR}$ layer giving $\alpha=0.890, \varepsilon_{\mathrm{C}}\left(300^{\circ} \mathrm{C}\right)=0.0389$, and $\varepsilon_{\mathrm{C}}\left(500^{\circ} \mathrm{C}\right)=0.0545$ [121]. $\quad \mathrm{A} \mathrm{SiO}_{2} / \mathrm{TiO}_{2} / a$-Si/Al selective absorber that utilizes boron-doped amorphous silicon has $\alpha=0.79-0.81$ and $\varepsilon_{C}\left(100^{\circ} \mathrm{C}\right)=0.12-0.16$ should be stable to $400^{\circ} \mathrm{C}$ in air [122]. Tandem absorbers have also been made with amorphous boron or amorphous alloys of boron and silicon, boron and germanium, and boron and molybdenum with solar absorptance between $87 \%$ and $94 \%$ and an operating temperature between $100^{\circ} \mathrm{C}$ and $500^{\circ} \mathrm{C}$ [123]. Although no recent research results were found, the silicon, germanium, and boron tandem absorber with AR coatings could be of interest as CSP absorbers.

\section{2.b. Multilayer}

4.2.b.1. Reactive DC magnetron sputtering of $\mathrm{SnO}_{\mathrm{x}}, \mathrm{Cr}, \mathrm{CrO}_{\mathrm{x}}$, stainless-steel oxides, and $\mathrm{AlN}_{\mathrm{x}}$ films on metal mirrors, $\mathrm{SS}$, and glass forms multilayer spectral selective absorbers (MSSA) as described in Table $3[124,125]$. The films were annealed at $500^{\circ} \mathrm{C}$ in air and should therefore be stable up to $500^{\circ} \mathrm{C}$. The $\mathrm{AlN}_{\mathrm{x}}$ films have the best solar selective properties and stability of these MSSA's considered; because the process has not been optimized, improvements would be expected with optimization and AR layers.

Tin oxide $\left(\mathrm{SnO}_{2}\right)$ is an excellent solar selective, protective, and AR layer because of its hardness and inertness. High solar reflectance is obtained below $1.1 \mu \mathrm{m}$ and low solar reflectance above $1.1 \mu \mathrm{m}$. $\mathrm{SnO}_{\mathrm{x}}: \mathrm{F}$ is quite flexible because the deep minimum around the plasma edge is tunable. Spectral selectivity is highly dependent on the preparation conditions, doping, and thickness of the films. A spectrally selective reflector was made by spray pyrolysis, a relatively inexpensive and simple process, by pyrolytically depositing fluorine-doped tin oxide $\left(\mathrm{SnO}_{\mathrm{x}}: \mathrm{F}\right)$ onto heated anodized

aluminum substrates $\left(380^{\circ}-450^{\circ} \mathrm{C}\right)$ [126]. Replacing the aluminum or anodized 
aluminum substrate with a metallic silver layer improved the solar selective properties. However, the silver would need to be replaced or stabilized for high temperature applications, because silver agglomerates at temperatures of $300^{\circ}$ and above. Additionally, composite solar absorber coatings where the glass substrate is spray coated with antimony-doped tin oxide, tin-doped indium oxide, or iron oxide followed by a second layer of antimony-doped tin oxide, fluorine-doped tin oxide, or tin-doped indium oxide exhibit an absorptivity of at least 0.85 and emittance less than 0.2 in the solar radiation range between 0.2 and $2 \mu$ [127]. The research on these multilayer absorbers is preliminary, and the temperature stability still needs to be determined, but they could be pertinent for CSP applications.

Table 3. Multilayer Selective Surfaces

\begin{tabular}{lll}
\hline Multilayer Film & Absorptance & Emittance $\left(100^{\circ} \mathrm{C}\right)$ \\
\hline $\mathrm{Cr}_{-} \mathrm{CrO}_{\mathrm{x}}$ & 0.88 & 0.20 \\
$\mathrm{Al}-\mathrm{CrO}_{\mathrm{x}}-\mathrm{Cr}_{2} \mathrm{O}_{3}$ & 0.83 & 0.13 \\
$\mathrm{Al}-\mathrm{AlN}_{\mathrm{x}}-\mathrm{AlN}$ & 0.97 & 0.10 \\
$\mathrm{Ag}-\mathrm{Sn}_{\mathrm{x}} \mathrm{O}_{\mathrm{x}}-\mathrm{SnO}_{2}$ & 0.90 & 0.26 \\
Stainless-steel oxides & 0.90 & 0.26 \\
\hline
\end{tabular}

4.2.b.2. Copper oxide $(\mathrm{CuO})$ selective coatings were prepared for flat-plate collectors by spraying dilute solutions of cupric nitrate onto a heated aluminum sheet and converted by heating above $170^{\circ} \mathrm{C}$ to black cupric oxide with $\alpha / \varepsilon\left(80^{\circ} \mathrm{C}\right)=0.93 / 0.11$ [128]. Highly polished silver, nickel, and platinum disks were electroplated with thin layers of $\mathrm{CuO}$ and cobalt oxide $\left(\mathrm{Co}_{3} \mathrm{O}_{4}\right)$ [129]. A thin layer of $\mathrm{CuO}\left(2.3 \times 10^{-5} \mathrm{~cm}\right)$ on polished silver gave an absorptivity of $76 \%$ with an emittance of $11 \%$; on polished nickel, $\alpha / \varepsilon\left(164^{\circ} \mathrm{C}\right)=0.81 / 0.17$ [129]. Above $600^{\circ} \mathrm{C}$ for at least $3 \mathrm{~h}$ in air, the silver crystallizes, and above $800^{\circ} \mathrm{C}$, the copper alloys with the platinum. In contrast, on platinum, the $\mathrm{CuO}$ had excellent stability at $600^{\circ} \mathrm{C}$ in air, but the copper also alloyed with the platinum above $800^{\circ} \mathrm{C}$. More recent work involves electroplating $\mathrm{CuO}$ on $\mathrm{SS}$ and $\mathrm{Cu}$ plate substrates for use in a linear solar Fresnel reflecting concentrating collector. The optical properties were $\alpha / \varepsilon\left(100^{\circ} \mathrm{C}\right)=0.91 / 0.18$ [130]. The selective coatings should be thermally stable up to $400^{\circ} \mathrm{C}$, with excellent adhesion to the substrate; but these have only been tested to $\sim 250^{\circ} \mathrm{C}$ in air. The $\mathrm{CuO}$ selective coatings are promising for concentrating applications if they are stable up to $400^{\circ} \mathrm{C}$.

Improvements to thermal stability of $\mathrm{Cu} / \mathrm{CuO}$ selective coatings have been made by the addition of other components [131-133]. The materials have been deposited by the low-cost technique of spin-coating or spraying metallo-organic resinate solutions onto the substrate and drying and calcining the coated substrate between $400^{\circ} \mathrm{C}$ and $800^{\circ} \mathrm{C}$. Suitable resinate solutions are prepared by treating an organic acid or mercaptan with the desired metal salt or combination of metal salts; resulting in a metal atom bonded to a sulphur or oxygen, which is bonded to carbon. The organic portion is burned off by firing the resinate films leaving a film of metal, metal oxide, or cermet. A multilayer solar-selective coating exhibiting high absorptivity, low emissivity, and resistance to degradation between temperatures of $300^{\circ} \mathrm{C}$ and $600{ }^{\circ} \mathrm{C}$ consists of an absorbing layer with a composition of 55\%-65\% Ag, 34.3\%-44.7\% $\mathrm{CuO}$, and $0.3 \%-0.7 \%$ rhodium oxide 
$\left(\mathrm{Rh}_{2} \mathrm{O}_{3}\right)$; a diffusion layer (between the absorbing layer and the substrate) of cerium oxide $\left(\mathrm{CeO}_{2}\right)$; and a metallic or glass substrate [131]. Films such as these maintained their solar absorptance of 0.9 and their thermal emittance of 0.1 for $2000 \mathrm{~h}$ at $500^{\circ} \mathrm{C}$ in air [131]. Changing the multilayer solar-selective coating to an absorbing layer with a composition of 50\%-75\% Ag, 9\%-49.9\% CuO, and $0.1 \%-1 \% \mathrm{Rh} / \mathrm{Rh}_{2} \mathrm{O}_{3}$, and $0 \%-15 \% \mathrm{Pt}$ (at the expense of the Ag); an interlayer of $\mathrm{Ag}$ or $\mathrm{Ag} / \mathrm{Pt}$ (between the absorbing layer and the substrate); and a metallic or glass substrate; and at least one AR layer of $\mathrm{CeO}_{2}$ improved the resistance to degradation. The coatings have a useful operating range of $300^{\circ} \mathrm{C}$ to $600^{\circ} \mathrm{C}$ and were tested to about $700^{\circ} \mathrm{C}$ in air for $2845 \mathrm{~h} \mathrm{[132].} \mathrm{Solar-selective}$ coatings made with $15 \%-35 \% \mathrm{CuO}, 5 \%-15 \%$ cobalt oxide $(\mathrm{CoO})$, and $60 \%-75 \%$ manganese oxide $\left(\mathrm{Mn}_{2} \mathrm{O}_{3}\right)$ over Pt- coated stainless steel substrates have improved stability, with absorptance values between 0.88 and 0.92 and emittance values of 0.06 0.12. They are resistant to degradation up to $700^{\circ} \mathrm{C}$ for $700 \mathrm{~h}$ in air and have a useful operating range of $300^{\circ} \mathrm{C}$ to $600^{\circ} \mathrm{C}$ [133]. $\mathrm{CuO}$ and, particularly, $\mathrm{CuO}$ metallo-organic composites (i.e., $\mathrm{Ag} / \mathrm{CuO} / \mathrm{Rh}_{2} \mathrm{O}_{3}, \mathrm{Ag} / \mathrm{Pt} / \mathrm{CuO} / \mathrm{Rh} / \mathrm{Rh}_{2} \mathrm{O}_{3}$, and $\mathrm{CuO} / \mathrm{CoO} / \mathrm{Mn}_{2} \mathrm{O}_{3}$ ) on Ptcoated stainless-steel substrates are promising low-cost, high-temperature, solar-selective coatings for concentrating applications.

4.2.b.3. Refractory metal borides $\mathrm{VB}_{2}, \mathrm{NbB}_{2}, \mathrm{TaB}_{2}, \mathrm{TiB}_{2}, \mathrm{ZrB}_{2}$, and $\mathrm{LaB}_{6}$, and $\mathrm{WSi}_{2}$ and $\mathrm{TiSi}_{2}$ coatings have been deposited by DC magnetron sputtering [134]. The coatings have potential applications as abrasion and chemical protection and as solar thermal control at very high temperatures. The melting temperature for bulk $\mathrm{NbB}_{2}, \mathrm{TaB}_{2}$, $\mathrm{TiB}_{2}$, and $\mathrm{LaB}_{6}$ are $3040^{\circ}, 3040^{\circ}, 3230^{\circ}$, and $2720^{\circ} \mathrm{C}$, respectively, and is near $2300^{\circ} \mathrm{C}$ for the silicides. The reflectance of the coatings at $10.6 \mu \mathrm{m}$ was 0.90 or greater except for $\mathrm{TaB}_{2}$, which had the lowest reflectance at 0.86. A six-layer thermal control coating was designed, where the design criteria were $\alpha / \varepsilon\left(100^{\circ} \mathrm{C}\right)=<0.3 />0.3$, with the highest possible reflectance at $10.6 \mu \mathrm{m}$. The coating was constructed with a $\mathrm{ZrN}$ base layer and $\mathrm{SiO}_{2} / \mathrm{Al}_{2} \mathrm{O}_{3}$ top layer. Multilayer coatings that strongly absorb and emit in the infrared were deposited with $\alpha / \varepsilon\left(100^{\circ} \mathrm{C}\right)=0.99 / 0.95-0.97(8-12 \mu \mathrm{m})$ and 0.95-0.97 (3-5 $\left.\mu \mathrm{m}\right)$ [134]. These coating were designed for space applications and have too high an emittance; but because of their high melting point, these materials may be of interest for CSP applications. The addition of a selective solar-transmitting coating, like a highly doped semiconductor (e.g., $\mathrm{SnO}_{2}: \mathrm{F}, \mathrm{SnO}_{2}: \mathrm{Sb}, \mathrm{In}_{2} \mathrm{SO}_{3}: \mathrm{Sn}$, and $\mathrm{ZnO}: \mathrm{Al}$ ), could be attempted to lower the emittance.

Bulk $\mathrm{ZrB}_{2}$ films prepared by $\mathrm{CVD}$ are solar selective with $\alpha / \varepsilon\left(100^{\circ} \mathrm{C}\right)=0.67$ $0.77 / 0.08-0.09[13,135] . \mathrm{ZrB}_{2}$ oxidizes slowly at $400^{\circ} \mathrm{C}$ in air, requiring a protective coating at higher temperatures. $\mathrm{Si}_{3} \mathrm{~N}_{4}$ AR coatings increase the solar absorptance to 0.88 0.93 while only increasing the emittance at $100^{\circ} \mathrm{C}$ from 0.08 to 0.10 . High-temperature aging studies at $400^{\circ} \mathrm{C}$ and $500^{\circ} \mathrm{C}$ in air show that $\mathrm{Si}_{3} \mathrm{~N}_{4} / \mathrm{ZrB}_{2}$ coatings are stable up to $1000 \mathrm{~h}$ [134]. Aging studies in air at $600^{\circ} \mathrm{C}$ show slight increases in the emittance after $300 \mathrm{~h}$ because of oxidation of the $\mathrm{Si}_{3} \mathrm{~N}_{4}$. CVD $\mathrm{ZrB}_{2}$ is a stable, high-temperature selective-solar absorber that with an improved AR protective coating could be of use for CSP applications. 


\section{2.c. Metal-dielectric composite}

\section{2.c.1. Single cermet layer}

4.2.c.1.1. Graded $\mathrm{Ni}, \mathrm{Co}, \mathrm{Mo}, \mathrm{W}, \mathrm{Pt}$ - $\mathrm{Al}_{2} \mathrm{O}_{3}$ cermets are stable in vacuum for applications from $350^{\circ} \mathrm{C}-800^{\circ} \mathrm{C}$, depending on the temperature stability of the metal used. Optimization studies for a graded sputtered 650- $\AA$-thick $\mathrm{Ni}-\mathrm{Al}_{2} \mathrm{O}_{3}$ cermet film on molybdenum-coated nickel-plated stainless steel with a 780 - $\AA$-thick $\mathrm{SiO}_{2}$ AR coating results in initial $\alpha=0.94$ and $\varepsilon=0.07$ [136]. The $\mathrm{Ni}-\mathrm{Al}_{2} \mathrm{O}_{3}$ films are stable in air up to $350^{\circ} \mathrm{C}-400^{\circ} \mathrm{C}$, depending on the substrate. With the addition of an $\mathrm{SiO}_{2} \mathrm{AR}$ coating, the films are stable up to $500^{\circ} \mathrm{C}$ in vacuum [136].

Experience from the Solar Energy Generating Systems (SEGS) plants has shown that the reliability and lifetime of the parabolic trough collector receiver tube or heat collection element (HCE) is the most significant issue for existing and future parabolic trough plants. Currently, Solel Solar Systems, Ltd. located in Israel, manufactures the only commercially available HCE. The HCE design used an evacuated receiver fabricated from stainless steel tubing with a cermet coating, a Pyrex ${ }^{\circledR}$ glass envelope coated with an anti-reflection coating, and a conventional glass-to-metal seal. The Mo$\mathrm{Al}_{2} \mathrm{O}_{3}$ cermet solar coating deposited by radio-frequency (RF) planar sputtering has good optical properties $\alpha / \varepsilon_{\mathrm{M}}\left(350^{\circ} \mathrm{C}\right)=0.96 / 0.16$ for $350^{\circ} \mathrm{C}<\mathrm{T}<500^{\circ} \mathrm{C}$ in vacuum [137]. An $\mathrm{Al}_{2} \mathrm{O}_{3}-\mathrm{Mo}_{-} \mathrm{Al}_{2} \mathrm{O}_{3}$ (AMA) coating on a Mo substrate with $\alpha / \varepsilon_{\mathrm{C}}\left(500^{\circ} \mathrm{C}\right)=0.85 / 0.11$ withstood $500 \mathrm{~h}$ at $920^{\circ} \mathrm{C}$ in vacuum [138]. At temperatures of $\sim 900^{\circ} \mathrm{C}$, the AMA on a Mo-coated stainless-steel substrate breaks down because of the diffusion of $\mathrm{Fe}$ and $\mathrm{Cr}$ from the steel. While the $\mathrm{Mo}-\mathrm{Al}_{2} \mathrm{O}_{3}$ cermet coating has demonstrated good thermal performance in evacuated HCE configurations, it has exhibited limited durability when exposed to air at parabolic trough operating temperatures. When the vacuum tube is compromised, after exposure to air at operating temperatures above $300^{\circ} \mathrm{C}$, the $\mathrm{Mo}-\mathrm{Al}_{2} \mathrm{O}_{3}$ cermet degrades and coats the glass tube with an opaque white precipitate that gives the tube the appearance of a fluorescent light. This rapid degradation of the cermet absorber coating significantly impacts both solar field performance and operational and maintenance (O\&M) costs. Air leakage at the glass-to-metal seal appears to be the primary cause of failure that results in a loss of vacuum and exposing the cermet coating to oxygen. Solel has developed a new HCE product an improved receiver tube called the Universal Vacuum Collector (UVAC). The UVAC uses a new multilayer $\mathrm{Al}_{2} \mathrm{O}_{3}$-based cermet that does not use Mo with an improved AR coating that is quoted to have more than $97 \%-98 \%$ absorptance and emittance of $0.1-0.07$ at $400^{\circ} \mathrm{C}$, which is stable in air and humidity at high temperatures with almost no degradation of optical parameters [139]. Testing of the performance and durability of the UVAC tubes in a solar field is ongoing.

4.2.c.1.2. Tungsten is well suited for selective cermet coatings, because of its high selectivity and high melting point. CVD, a low-cost deposition technique, has been used to produce amorphous $\mathrm{W}-\mathrm{WO}_{\mathrm{x}}-\mathrm{Al}_{2} \mathrm{O}_{3}$ cermet films. After annealing at $800^{\circ} \mathrm{C}$ for 1 $\mathrm{h}$ in hydrogen, the films consisted of $\mathrm{W}-\mathrm{Al}_{2} \mathrm{O}_{3}$ on $\mathrm{Cu}$ substrates having $\alpha / \varepsilon\left(100^{\circ} \mathrm{C}\right)=0.85 / 0.04$ for $\mathrm{T}=500^{\circ} \mathrm{C}$ [140]. The spectral hemispherical emissivity of platinum at $0.9 \mu \mathrm{m}$ rises from 0.21 to $0.26 \pm 0.04$ between $900^{\circ}-1200^{\circ} \mathrm{C}$ [141]. RFsputtered $\mathrm{Pt}-\mathrm{Al}_{2} \mathrm{O}_{3}$ cermets with graded and uniform $\mathrm{Pt}$ compositions with $\mathrm{Al}_{2} \mathrm{O}_{3} \mathrm{AR}$ layers and $\mathrm{Al}_{2} \mathrm{O}_{3}-\mathrm{Pt}-\mathrm{Al}_{2} \mathrm{O}_{3}$ compositions were stable in air at $600^{\circ} \mathrm{C}$ with 
$\alpha / \varepsilon\left(100^{\circ} \mathrm{C}\right)=0.90-0.97 / 0.08$ [142,143]. The addition of a porous $\mathrm{SiO}_{\mathrm{x}}$ AR layer can increase solar absorptance above this limit to 0.98 [144]. Graded cermets with Mo have been used for CSP applications. Replacing the Ni or Mo with $\mathrm{W}, \mathrm{Pt}$, or other highmelting-point materials of should increase the temperature at which the cermet can be used.

4.2.c.1.3. Several electrodeposition techniques are used to prepare black cobalt $\left(\mathrm{Co}_{3} \mathrm{O}_{4} / \mathrm{Co}, \mathrm{Co}_{\mathrm{x}} \mathrm{O}_{\mathrm{y}}\right)$ including depositing the $\mathrm{Co}_{3} \mathrm{O}_{4}$ directly; depositing $\mathrm{Co}$ metal and oxidizing it thermally, chemically, or with a combination of electrolytes; and spray deposition of black cobalt [129,145-151]. Researchers using different processes and combinations of cobalt oxides report stability in air for $400^{\circ}-650^{\circ} \mathrm{C}$ from $80-1000 \mathrm{~h}$. In addition, electroplated $\mathrm{Co}_{3} \mathrm{O}_{4}$ on silver was reported to be in excellent condition after 12 $\mathrm{h}$ at $900^{\circ} \mathrm{C}$ in air, and $\mathrm{Co}_{3} \mathrm{O}_{4}$ on platinum showed no alloying nor loss of blackness after $26 \mathrm{~h}$ at $1100^{\circ} \mathrm{C}$ in air [129]. Black nickel-cobalt has $\alpha / \varepsilon\left(100^{\circ} \mathrm{C}\right)=0.95 / 0.10$ and is expected to be less expensive than black Co, but to have higher temperature and better corrosion resistance than black $\mathrm{Ni}$ [152]. Cobalt oxides on noble metals are stable to air exposure for $1005 \mathrm{~h}$ at $500^{\circ} \mathrm{C}$ with $\alpha / \varepsilon\left(100^{\circ} \mathrm{C}\right)=0.86-0.88-/ 0.1-0.2$ [153]. The addition of manganese $(\mathrm{Mn})$ increases the reflectance above $1200 \mathrm{~nm}$ and reduces the thermal emittance. Adding colloidal silica increases the solar absorptance between 400 and 800 $\mathrm{nm}$ and increases the low-temperature emittance; but at $300^{\circ} \mathrm{C}$, the emittance is comparable to that without silica. This gives $\alpha / \varepsilon\left(100^{\circ} \mathrm{C}\right)=0.88-0.90 / 0.09-0.17$ and $\varepsilon_{\mathrm{M}}\left(300^{\circ} \mathrm{C}\right)=0.18-0.29$ [154]. Titanium-tin oxide protective films have been deposited on black cobalt photothermal absorbers giving an absorptance of 0.94 and emittance of 0.34 after $100 \mathrm{~h}$ of $400^{\circ} \mathrm{C}$ thermal treatment [155]. The black cobalt construction is a good candidate as a high-temperature $\left(400^{\circ} \mathrm{C}\right)$ selective absorber coating.

4.2.c.1.4. Black moly, i.e., molybdenum $\left(\mathrm{Mo}-\mathrm{MoO}_{2}\right)$ is a composite structure composed of a $\mathrm{MoO}_{2}$ matrix in which pure $\mathrm{Mo}$ is embedded, giving an $\alpha / \varepsilon_{\mathrm{C}}\left(500^{\circ} \mathrm{C}\right)=0.85 / 0.33$ [156]. When passivated with $\mathrm{Si}_{3} \mathrm{~N}_{4}$, the spectral selectivity improves to $\alpha / \varepsilon_{\mathrm{C}}\left(500^{\circ} \mathrm{C}\right)=0.94 / 0.30$. The films have been tested for $2000 \mathrm{~h}$ at $500^{\circ} \mathrm{C}$ in vacuum and $1500 \mathrm{~h}$ at $350^{\circ} \mathrm{C}$ in air without deterioration of their optical properties [157]. Earlier films passivated with either $\mathrm{Al}_{2} \mathrm{O}_{3}$ or $\mathrm{Si}_{3} \mathrm{~N}_{4}$ have been tested for $160 \mathrm{~h}$ at $500^{\circ} \mathrm{C}$ in air without measurable deterioration of their IR reflectance [158]. More research is needed, but black moly is a good candidate as a high-temperature $\left(500^{\circ} \mathrm{C}\right)$ selective absorber coating for CSP applications.

4.2.c.1.5. "Black tungsten" $\left(\mathrm{W}-\mathrm{WO}_{\mathrm{x}}\right)$ films have been prepared by CVD on various substrates, giving an $\alpha / \varepsilon\left(100^{\circ} \mathrm{C}\right)=0.83 / 0.15$, where $\varepsilon_{\mathrm{C}}\left(300^{\circ} \mathrm{C}\right)=0.22$ and $\varepsilon_{\mathrm{C}}\left(500^{\circ} \mathrm{C}\right)=0.28[156,158-160]$. The optical properties of black tungsten films are very dependent on the deposition parameters [157]. Compared to molybdenum, tungsten has a greater spectral selectivity, as well as a greater resistance to oxidation. The sublimation decomposition or melting of $\mathrm{WO}_{2}$ and intermediate tungsten oxides occurs at temperatures above $1500^{\circ} \mathrm{C}$. The annealing temperature of the black tungsten films is greater than the anticipated operating temperature of $500^{\circ} \mathrm{C}$. Modeling suggests that the selective properties would be stable up to $800^{\circ} \mathrm{C}$ [156]. By analogy to black moly, black tungsten is expected to have good thermal stability in this range and be a good candidate for a high-temperature absorber coatings, but more research is needed. 


\section{2.c.2. Multiple cermet layers}

4.2.c.2.1. A double-cermet layer structure (Figure 5) developed for solarselective coatings has photothermal efficiency higher than that of a single graded cermet layer [31,161]. A double $\mathrm{Mo}-\mathrm{Al}_{2} \mathrm{O}_{3}$ cermet layer deposited by vacuum co-evaporation on a $\mathrm{Cu}$ substrate has a $\alpha / \varepsilon_{\mathrm{C}}\left(350^{\circ} \mathrm{C}\right)=0.96 / 0.08$ [162]. Single-cermet SS-AlN, W-AlN, or Mo-AlN layers have been studied and have excellent properties, with $\alpha / \varepsilon\left(100^{\circ} \mathrm{C}\right)=0.92 / 0.06-0.10$ [163]. Double W-AIN and Mo-AlN cermet solar coatings were deposited by two-target reactive DC sputtering. The $\alpha / \varepsilon_{\mathrm{C}}\left(350^{\circ} \mathrm{C}\right)=0.92-0.94 / 0.08$ 0.10 for W-AlN and Mo-AlN double coatings are stable at $500^{\circ} \mathrm{C}$ in vacuum for $1 \mathrm{~h} \mathrm{[164-}$ 166]. Reactive DC sputtering has a faster deposition rate and lower equipment cost than RF sputtering, and the double-cermet selective coating is easier to deposit compared to the graded-cermet layer. In addition, the complexity of the RF equipment requires personnel with much more education and training than that needed to maintain and run the DC equipment. The double-layer cermet coating is claimed to be 5 to 10 times lower in cost to produce than the Solel RF Mo- $\mathrm{Al}_{2} \mathrm{O}_{3}$ coatings [167]. SS-AlN double-cermet solar selective films have a $\alpha / \varepsilon\left(100^{\circ} \mathrm{C}\right)=0.95 / 0.05$ and $\alpha / \varepsilon_{\mathrm{C}}\left(350^{\circ} \mathrm{C}\right)=0.96 / 0.10$ [168]. TurboSun in China produced 3.5 million commercial U-shaped all-glass evacuated solar collector tubes in 1997 for low-temperature hot-water collectors in their dual-chamber reactive DC magnetron sputtering coaters. These SS-AIN double-cermet glass-tubes are thermally stable between $350^{\circ} \mathrm{C}-500^{\circ} \mathrm{C}$ in vacuum and are lower in cost than the Solel tubes [169]. W/AlN or Mo/AlN double-cermets are being developed, that can also be produced in the TurboSun coaters, which should be stable at temperatures higher than $500^{\circ} \mathrm{C}[170]$. As yet the double cermet coatings have not been physically optimized, which should further improve their properties.

From optimization calculations, using a material with a lower refractive index such as $\mathrm{MgF}_{2}$ or a double-AR layer could increase the solar absorption. By calculation, an optimized Al-AlON double-cermet solar coating with $\mathrm{MgF}_{2}$ and $\mathrm{AlON}$ double $\mathrm{AR}$ layers, has identical solar performance to an optimized triple-cermet layer with an $\mathrm{MgF}_{2}$ AR layer $\left[\alpha / \varepsilon\left(100^{\circ} \mathrm{C}\right)=0.989 / 0.059\right]$ [171]. Thermal emittance can be further reduced using a lower emittance metal such as, "oxide-free" aluminum, copper, silver, or platinum. The tubes using the W/AlN double cermet could be useful for CSP applications and warrant testing. Research using the double-cermet structure with a cermet that has a higher temperature stability on high-temperature steel could be extremely fruitful for CSP applications.

4.2.c.2.2. Optimization studies were done on antireflected 4-layer $\mathrm{V}-\mathrm{Al}_{2} \mathrm{O}_{3}$, W$\mathrm{Al}_{2} \mathrm{O}_{3}, \quad \mathrm{Cr}-\mathrm{Al}_{2} \mathrm{O}_{3}, \mathrm{Co}-\mathrm{SiO}_{2}, \quad \mathrm{Cr}-\mathrm{SiO}_{2}$, and $\mathrm{Ni}-\mathrm{SiO}_{2}$ cermets, where the cermet compositional gradient metal volume fractions (VF) vary from 0.5 to 0.8 . Independent of material, the $0.7 \mathrm{VF}$ gives the best result, resulting in $\alpha / \varepsilon\left(100^{\circ} \mathrm{C}\right)=0.97 / 0.13-0.05$ [172]. A graded-index metallic nickel in quartz $\mathrm{Ni}: \mathrm{SiO}_{2}$ cermet selective surface was made by co-sputtering, with VF ranging from $10 \%-90 \%$ from the top (AR) to bottom (base layer) on aluminum and copper substrates. Films were prepared with $\alpha=0.90-0.96$ and $\varepsilon=0.03$ 0.14 [173]. The effect of the AR coating is to minimize the optical interference effects within the film and to increase the solar absorptance $4 \%$ from 0.92 to 0.96 . Thin films of $\mathrm{Cr}-\mathrm{SiO}$ cermets on metal substrates show spectral selectivity. Aging studies in the temperature range from $400^{\circ}-800^{\circ} \mathrm{C}$ in an argon atmosphere for $1000 \mathrm{~h}$ (42 days) show 
that the structure changes within the first day of annealing and then remains constant [174]. The situation is not expected to change for longer periods of time, because no other changes were observed within 40 days, even after annealing at a temperature of $800^{\circ} \mathrm{C}$. Similar to the double-cermet structure, this research has promise for CSP applications, but more research is needed.

\section{2.c.3. Materials used as either cermets or multilayers}

4.2.c.3.1. Thermodynamically stable quasicrystal-forming alloys (i.e., AlCuFe, $\mathrm{AlCuRu}$, and AlMnPd films) can be used as selective absorbers. "Materials with an icosahedral point group or other crystals of forbidden rotational symmetries are referred to as "quasicrystals"" [175]. AlMn alloys produced by melt spinning show five-fold rotational symmetry that is incompatible with the transitional symmetry of crystals. Reflectance from $300 \mathrm{~nm}$ to $20 \mu \mathrm{m}$ is about 0.6 and is nearly independent of wavelength for all stable ordered icosahedral quasicrystals [175]. Quasicrystals exhibit high thermal and chemical stability. Quasicrystals show no selective properties at all, but thin (10-12$\mathrm{nm}$ ) film stacks on a highly reflective substrate or in a cermet show the desired properties [176]. Sputtering thin films of $\mathrm{AlCuFe}$ and $\mathrm{AlCuFeCr}$ on very rough copper films and silicon has produced such absorbers. Dielectric AR coatings of alumina and float glass were necessary to give the required optical properties. Thin $(10-\mathrm{nm})$ quasicrystal films sandwiched between dielectric layers on a copper substrate were predicted to have $\alpha / \varepsilon\left(100^{\circ} \mathrm{C}\right)=0.91 / 0.05$ [177]. At near-normal angle of incidence, the properties were found to be $\alpha / \varepsilon\left(100^{\circ} \mathrm{C}\right)=0.90 / 0.025$ [177]. Near-normal emittance is generally lower than hemispherical emittance. Thick-sputtered films and absorbers on silicon demonstrated excellent stability for $450 \mathrm{~h}$ at $400^{\circ} \mathrm{C}$ against oxidation in air [177]. Humidity stability depends strongly on the choice of materials. The $\mathrm{AlCuFeCr} /$ float glass combination was stable, but AlCuFe/alumina was destroyed rapidly. Cermet absorbers made using a fill factor of 0.2-0.4 quasicrystal in a $\mathrm{TiO}_{2}, \mathrm{HfO}_{2}, \mathrm{Y}_{2} \mathrm{O}_{3}$, and $\mathrm{Al}_{2} \mathrm{O}_{3}$ dielectric matrix gave an $\alpha / \varepsilon\left(100^{\circ} \mathrm{C}\right)=0.86-0.92 / 0.031-0.05$ with $\varepsilon_{\mathrm{C}}\left(550^{\circ} \mathrm{C}\right)=0.05-0.12$ [175]. Quasicrystal cermets in an $\mathrm{Al}_{2} \mathrm{O}_{3}$ dielectric matrix (patent includes $\mathrm{TiO}_{2}, \mathrm{ZrO}_{2}, \mathrm{Y}_{2} \mathrm{O}_{3}, \mathrm{SiO}_{2}, \mathrm{Ta}_{2} \mathrm{O}_{5}, \mathrm{WO}_{3}$, $\mathrm{V}_{2} \mathrm{O}_{5}, \mathrm{Nb}_{2} \mathrm{O}_{5}$, and $\mathrm{CeO}_{2}$ ) made by the sol-gel technique where the liquid was applied by spraying or spin coating and heat treated in air at $500^{\circ}$ to $600^{\circ} \mathrm{C}$ had comparable optical properties [178]. Adding a dielectric film with a low index of refraction $\left(\mathrm{AlF}_{\mathrm{x}} \mathrm{O}_{\mathrm{y}}\right)$ increased the solar absorptance [175]. The cost of the quasicrystal solar selective coating should nominally be that of a film sputtered from the elemental metals, because the films were sputtered from a circular target with pie-shaped wedges of the elemental metals ( $\mathrm{Al}$, $\mathrm{Cu}, \mathrm{Fe}$, and $\mathrm{Cr}$ ) rotating at $10 \mathrm{~Hz}$. The wedges are the appropriate sizes to give the desired stoichiometry with the axis of rotation centered in the middle. Theoretically, quasicrystals can achieve high solar absorptance $(>0.9)$ and low thermal emittance $(<0.05$ at $\left.400^{\circ} \mathrm{C}\right)$ with high-temperature stability $\left(500^{\circ} \mathrm{C}\right)$ [179]. More research is needed on quasicrystal thin films and cermets, but this promising material could be suitable for CSP applications.

4.2.c.3.2. Because of their high index of refraction and significant chemical and mechanical stability, cermets made with $\mathrm{TiO}_{2}$ and $\mathrm{ZrO}_{2}$ plus additives of noble metals such as $\mathrm{Au}$ and $\mathrm{Pd}$ have been found to be solar selective. Selective absorber cermets $\left(33 \% \mathrm{Au} / 67 \% \mathrm{TiO}_{2}\right)$ made by inexpensive sol-gel techniques have good optical selectivity 
$\alpha / \varepsilon_{\mathrm{C}}\left(400^{\circ} \mathrm{C}\right)=0.80 / 0.01$ and thermal durability $\left(>500^{\circ} \mathrm{C}\right.$ in air) [180]. An AR layer increases absorptance up to 0.85 . Thermal durability has been tested in an oven at temperatures above $500^{\circ} \mathrm{C}$ at ambient conditions with no degradation in performance. Thin gold/silica and gold/titania cermets have high solar absorptance and low emittance. Copper, platinum, silver, and palladium cermets have been also been prepared, but the resulting absorption is not high enough. Gold cermets give the best results because they have the highest intrinsic absorption coefficient. Selectivity improves using thinner cermet layers with higher metal content and interference effects. $\mathrm{Au} / \mathrm{MgO}$ cermets deposited by RF sputtering on stainless-steel coated with molybdenum give $\alpha / \varepsilon\left(100^{\circ} \mathrm{C}\right)=0.90-0.93 / 0.04-0.1$. Such materials have been heated in air to $400^{\circ} \mathrm{C}$ for 64 $\mathrm{h}$, and are expected to be thermally stable up to $400^{\circ} \mathrm{C}$, in view of the separate stability of $\mathrm{MgO}$ and $\mathrm{Au}$ [181]. Multilayer coating systems consisting nominally of one quarterwave thick $\mathrm{Mo}$ and $\mathrm{MgF}_{2}\left(\mathrm{MgF}_{2} / \mathrm{Mo} / \mathrm{CeO}_{2}\right.$ on $\mathrm{Mo}, \mathrm{MgF}_{2} / \mathrm{Mo} / \mathrm{MgF}_{2} / \mathrm{Mo} / \mathrm{MgF}_{2}$ on $\mathrm{Mo}$, $\mathrm{MgF}_{2} / \mathrm{CeO}_{2} / \mathrm{Mo} / \mathrm{MgF} 2 / \mathrm{CeO}_{2}$ on $\mathrm{Mo}$, and $\mathrm{Al}_{2} \mathrm{O}_{3} / \mathrm{Mo} / \mathrm{Al}_{2} \mathrm{O}_{3} / \mathrm{Mo} / \mathrm{Al}_{2} \mathrm{O}_{3} / \mathrm{Mo} / \mathrm{Al}_{2} \mathrm{O}_{3}$ on $\mathrm{Mo}$ ) deposited by electron-beam evaporation are stable to $540^{\circ} \mathrm{C}$ in vacuum with $\alpha=0.85-0.91$ and $\varepsilon_{\mathrm{M}}\left(260^{\circ} \mathrm{C}\right.$ and $\left.538^{\circ} \mathrm{C}\right)=0.06-0.16$ [182]. $\mathrm{Au} / \mathrm{MgF}_{2}$ or $\mathrm{CeO}_{2}$ cermet or multilayer films may also be of interest because of the performance and stability of the $\mathrm{Mo} / \mathrm{MgF}_{2}$ films [183]. Initial results are encouraging in $\mathrm{TiO}_{2}$ sol-gel coatings, where $\mathrm{MnO}$ was substituted for the more expensive noble metals [160]. Likewise, solar-selective coatings with Sn-doped $\operatorname{In}_{2} \mathrm{O}_{3} / \mathrm{MgF}_{2}$ have $\alpha / \varepsilon_{\mathrm{C}}\left(121^{\circ} \mathrm{C}\right)=0.90 / 0.081$ [184]. In addition, cermets have been made for other applications with $\mathrm{Au}$ or $\mathrm{Pt}$ and $\mathrm{SiO}_{2}$ that could also be used for absorbers [185-188]. In 1977, absorber coating films containing gold were estimated to cost $\$ 0.88 / \mathrm{ft}^{2}$; scaling to current precious metal prices, the same film would cost $\$ 1.63 / \mathrm{ft}^{2}$, and by analogy, films containing platinum would roughly cost $\$ 2.55 / \mathrm{ft}^{2}$ [189]. Solar-selective cermets made with $\mathrm{Au}$ or Pt and $\mathrm{ZrO}_{2}$ could be of high interest as $\mathrm{ZrO}_{2}$ has three phases depending on the temperature. The monoclinic phase is formed from room temperature to $1150^{\circ} \mathrm{C}$, the tetragonal phase is stable between $1150-2370^{\circ} \mathrm{C}$, and the cubic phase is formed at temperatures higher than $2370^{\circ} \mathrm{C}$. The tetragonal and cubic phase can be stabilized at room temperature by different concentrations of $\mathrm{Y}_{2} \mathrm{O}_{3}, \mathrm{Al}_{2} \mathrm{O}_{3}$, $\mathrm{CeO}_{2}$, and other materials. In general, the gold- and platinum-containing cermets have the potential to operate at higher temperatures and using the sol-gel process is a low-cost feasible technique.

4.2.c.3.3. Titanium, zirconium, or hafnium metal carbides, oxides, and nitrides have a high degree of spectral selectivity. The group IV metal compounds are of the general formula $M C_{x} O_{y} N_{z}, \mathrm{M}=\mathrm{Ti}$, Zr, or Hf, and $\mathrm{x}+\mathrm{y}+\mathrm{z}<2$. In these tandem absorberreflector films, of the compositions studied, substoichiometric compounds of $\mathrm{TiN}_{\mathrm{x}}, \mathrm{ZrN}_{\mathrm{x}}$, and $\mathrm{ZrC}_{\mathrm{x}} \mathrm{N}_{\mathrm{y}}$ (on silver) had the best combination of high solar absorptance and low thermal emittance. The absorptance and emittance calculated from reflectance data are summarized in Table 4 [190]. $\mathrm{TiN}_{\mathrm{x}}$ and $\mathrm{ZrN}_{\mathrm{x}}$ had nearly identical optical properties, but for $\mathrm{HfN}_{\mathrm{x}}$ the absorptance was lower and the emittance higher. $\mathrm{ZrC}$ was the best pure carbide film. Adding carbon to form zirconium carbonitride $\left(\mathrm{ZrC}_{\mathrm{x}} \mathrm{N}_{\mathrm{y}}\right)$ increased the solar absorptance by $6 \%$. Oxygen, either as suboxides $\left(\mathrm{TiO}_{\mathrm{x}}\right.$ and $\left.\mathrm{ZrO}_{\mathrm{x}}\right)$ or substituted into the nitrides and carbonitrides $\left(\mathrm{ZrO}_{\mathrm{x}} \mathrm{N}_{\mathrm{y}}\right.$ or $\left.\mathrm{ZrC}_{\mathrm{x}} \mathrm{O}_{\mathrm{y}} \mathrm{N}_{\mathrm{z}}\right)$ lowered absorptance and raised emittance. A notable exception was an oxidized $\mathrm{Zr}$ film with an absorption of 0.93. Solar absorptance was increased by $8 \%$ by replacing the aluminum reflective film with an ultrafine dendritic aluminum. Absorptance was also increased by $5 \%$ by the addition of 
an $\mathrm{AlO}_{\mathrm{x}} \mathrm{AR}$ layer. Calculated absorptance and emittance values were confirmed for a number of samples by normal reflectance and total emittance measurements carried out at elevated temperature. Depending on the sample, there was good agreement with roomtemperature measurements up to $400^{\circ}-600^{\circ} \mathrm{C}$. The thermal stability of these tandem absorber-reflector films was studied, and several absorbers survived cumulative heating periods of $500 \mathrm{~h}$ in vacuum up to the maximum test temperature, $700^{\circ} \mathrm{C}$ [191]. The addition of a thin $\mathrm{Al}_{2} \mathrm{O}_{3}$ diffusion barrier improved the stability in air from $125^{\circ} \mathrm{C}$ to $175^{\circ} \mathrm{C}$ [192]. The stability of the tandem films at high temperatures in vacuum was limited to the agglomeration of the metal reflective film, for silver about $350^{\circ} \mathrm{C}$. The use of thin layers of $\mathrm{Cr}_{2} \mathrm{O}_{3}, \mathrm{Al}_{2} \mathrm{O}_{3}, \mathrm{SiO}_{2}$, or other oxide under the metal has been found to stabilize the silver and aluminum and inhibit agglomeration at high temperatures [193]. Agglomeration has been inhibited at temperatures up to $800^{\circ} \mathrm{C}$ for one hour, but the limit of silver stability achieved was about $500^{\circ} \mathrm{C}[194,195]$. The selective optical properties of sputtered $\mathrm{ZrC}_{\mathrm{x}} \mathrm{N}_{\mathrm{y}}$ on aluminum-coated oxidized stainless-steel are thermally stable from room temperature to $600^{\circ} \mathrm{C}$ (likely in vacuum but was not specified) [193]. Sputtered selective absorbers with the structure $\mathrm{Al}_{2} \mathrm{O}_{3} / \mathrm{ZrC}_{\mathrm{x}} \mathrm{N}_{\mathrm{y}} / \mathrm{Ag}$ have good optical selectivity with $\alpha / \varepsilon_{\mathrm{C}}\left(325^{\circ} \mathrm{C}\right)=0.91 / 0.05$ at an operating temperature of $700^{\circ} \mathrm{C}$ in vacuum and $175^{\circ} \mathrm{C}$ in air [196]. Sputtered $\mathrm{ZrO}_{\mathrm{x}} / \mathrm{ZrC}_{\mathrm{x}} / \mathrm{Zr}$ absorbers have $\alpha / \varepsilon\left(20^{\circ} \mathrm{C}\right)=0.90 / 0.05$ and are thermally stable in vacuum on stainless-steel and quartz substrates up to $600^{\circ} \mathrm{C}$ and $800^{\circ} \mathrm{C}$, respectively [195]. "Raney nickel" type alloys were prepared by co-sputtering nickel, zirconium, or molybdenum with aluminum. After the aluminum was etched out of the $\mathrm{ZrAl}_{3}$ film, a very fine open structure resulted that had a solar absorptance greater than 0.95 and a calculated emittance at $327^{\circ} \mathrm{C}$ of 0.29 [194].

Table 4. Composition and Properties of Selected $\mathrm{MC}_{\mathrm{x}} \mathrm{O}_{\mathrm{y}} \mathrm{N}_{\mathrm{z}}$ absorbers

\begin{tabular}{|c|c|c|c|c|}
\hline $\begin{array}{l}\mathrm{AR} \\
\text { layer }\end{array}$ & $\begin{array}{l}\text { Absorbing } \\
\text { layer }\end{array}$ & $\begin{array}{l}\text { Reflective } \\
\text { layer }\end{array}$ & $\alpha^{1}$ & $\varepsilon\left(327^{\circ} \mathrm{C}\right)^{1}$ \\
\hline \multirow{11}{*}{$\mathrm{AlO}_{\mathrm{x}}$} & $\mathrm{ZrO}_{\mathrm{x}}$ & $\mathrm{Ag}$ & 0.72 & 0.42 \\
\hline & $\mathrm{TiO}_{\mathrm{x}}$ & $\mathrm{Ag}$ & 0.80 & 0.067 \\
\hline & $\mathrm{CrO}_{\mathrm{x}}$ & $\mathrm{Ag}$ & 0.74 & 0.079 \\
\hline & $\mathrm{ZrN}_{\mathrm{x}}$ & $\mathrm{Ag}$ & 0.86 & 0.039 \\
\hline & $\operatorname{TiN}_{x}$ & $\mathrm{Ag}$ & 0.80 & 0.034 \\
\hline & $\operatorname{TiN}_{x}$ & $\mathrm{Ag}$ & 0.94 & 0.170 \\
\hline & $\mathrm{HfNx}$ & $\mathrm{Ag}$ & 0.76 & 0.027 \\
\hline & $\mathrm{ZrC}$ & $\mathrm{Ag}$ & 0.81 & 0.075 \\
\hline & $\mathrm{ZrO}_{\mathrm{x}} \mathrm{N}_{\mathrm{y}}{ }^{2}$ & $\mathrm{Ag}$ & 0.93 & 0.071 \\
\hline & $\mathrm{ZrC}_{\mathrm{x}} \mathrm{N}_{\mathrm{y}}$ & $\mathrm{Ag}$ & 0.88 & 0.040 \\
\hline & $\mathrm{ZrC}_{\mathrm{x}} \mathrm{N}_{\mathrm{y}}$ & $\mathrm{Al}$ & 0.85 & 0.074 \\
\hline \multirow{5}{*}{$\begin{array}{l}\mathrm{AlO}_{\mathrm{x}} \\
\mathrm{ZrO}_{\mathrm{x}}\end{array}$} & $\mathrm{ZrC}_{\mathrm{x}} \mathrm{N}_{\mathrm{y}}$ & $\mathrm{Al}^{3}$ & 0.93 & 0.071 \\
\hline & $\mathrm{ZrC}_{\mathrm{x}} \mathrm{N}_{\mathrm{y}}$ & $\mathrm{Ag}$ & 0.91 & 0.048 \\
\hline & $\mathrm{ZrC}_{\mathrm{x}} \mathrm{N}_{\mathrm{y}}$ & $\mathrm{Ag}$ & 0.64 & 0.014 \\
\hline & $\mathrm{ZrC}_{\mathrm{x}} \mathrm{O}_{\mathrm{y}} \mathrm{N}_{\mathrm{z}}$ & $\mathrm{Ag}$ & 0.66 & 0.020 \\
\hline & $\mathrm{ZrAl}_{3}{ }^{4}$ & $\mathrm{Ag}$ & 0.97 & 0.290 \\
\hline
\end{tabular}

Methods of combining the characteristics of controlled morphology with intrinsic selectivity deserve further investigation. This work was discontinued in September 1976 
and was not resumed. Similar research in Japan appears to have metamorphosed into superconductivity work in 1982 [195]. More recent research incorporated the selective properties of pores and created a temperature-stable $\left(400^{\circ} \mathrm{C}\right)$, solar-selective coating with a void volume of $22 \%-26 \%$ deposited by reactive evaporation of $\mathrm{Ti}, \mathrm{Zr}$, and $\mathrm{Hf}$ with nitrogen and oxygen onto copper, molybdenum, or aluminum substrates with a $\mathrm{SiO}_{2} \mathrm{AR}$ layer [196]. Solar absorbers could be made by reactive sputtering the nitrides of zirconium, yttrium, cerium, thorium, and europium (i.e., $\mathrm{ZrN}, \mathrm{YN}, \mathrm{CeN}, \mathrm{TIN}$, and $\mathrm{EuN}$ ), which are transparent in the infrared, abrasion resistant, inert, very hard, and stable at temperatures in excess of $500^{\circ} \mathrm{C}$ for long periods of time [197]. A recent patent includes $\mathrm{ZrN}$, TiN, HfN, CrN, or $\mathrm{Ti}_{\mathrm{x}} \mathrm{Al}_{1-\mathrm{x}} \mathrm{N}$ cermets in an $\mathrm{Al}_{2} \mathrm{O}_{3}$ dielectric matrix (patent includes $\mathrm{TiO}_{2}, \mathrm{ZrO}_{2}, \mathrm{Y}_{2} \mathrm{O}_{3}, \mathrm{SiO}_{2}, \mathrm{Ta}_{2} \mathrm{O}_{5}, \mathrm{WO}_{3}, \mathrm{~V}_{2} \mathrm{O}_{5}, \mathrm{Nb}_{2} \mathrm{O}_{5}$, and $\mathrm{CeO}_{2}$ ) made by the sol-gel technique, where the liquid was applied by spraying or spin coating and heat treated in air at $500^{\circ} \mathrm{C}$ to $600^{\circ} \mathrm{C}$ [143]. Additionally, a thin surface film of metal oxynitrides (niobium, tantalum, vanadium, zirconium, titanium, and molybdenum) can be made by coating a substrate with a slurry of a metal halide in a liquid volatile carrier and converting the metal halide to a metal oxide or oxynitride by heating it with oxygen and nitrogen [197]. These materials have some of the highest melting points in nature, with $\mathrm{HfC}$ having the highest melting point at $3316^{\circ} \mathrm{C}$. The optical properties of these materials have a high degree of flexibility, and with further research, including replacing the stabilized silver with a more thermally stable reflective metal, could be a viable hightemperature absorber for the CSP program.

4.2.c.3.4. Titanium nitride (TiN) and titanium aluminum nitride $\left(\operatorname{Ti}_{1_{-x}} A l_{x} N\right)$ have high hardness, improved wear, corrosion, and oxidation resistance. $\mathrm{Ti}_{1-\mathrm{x}} \mathrm{Al}_{\mathrm{x}} \mathrm{N}$ is oxidation resistant at high temperatures in air $\left(750^{\circ}-900^{\circ} \mathrm{C}\right)$, whereas $\mathrm{TiN}$ oxidizes at $500^{\circ} \mathrm{C}$ [198]. The normal emittance of TiN ranges from 0.40 to 0.14 [199]. Single-layer $\mathrm{Ti}_{1-\mathrm{x}} \mathrm{Al}_{\mathrm{x}} \mathrm{N}$ films deposited by reactive magnetron sputtering on copper and aluminum achieved $\alpha\left(100^{\circ} \mathrm{C}\right)=0.80$, but no emittance values were reported [200]. Higher absorptance can be reached by designing a multilayer absorber based on $\mathrm{Ti}_{1-\mathrm{x}} \mathrm{Al}_{\mathrm{x}} \mathrm{N}$ films in combination with an AR coating, or by using gradient layers. The microstructure is columnar, so a cermet made with pores with a diameter on the order of $30 \mathrm{~nm}$ is also possible [198]. Varying the aluminum and nitrogen content changes the hardness, color, optical properties, composition, microstructure, and pore and grain size. These materials have a high degree of flexibility in the optical properties and with further research, could be a practical hightemperature absorber for the CSP program.

\section{2.c.4. Cermet Paints}

4.2.c.4.1. High-temperature solar-selective coatings comprising thermally stable metal oxides and ferrites mixtures have solar absorptance greater than 0.9 at wavelengths from 0.35 to 3.0 microns and solar emittance greater than 0.45 at wavelengths greater than 3 microns [201]. The metal oxides are generally represented as $\mathrm{M}_{b} \mathrm{O}_{c}$, where $\mathrm{M}$ is selected from nickel, cobalt, strontium, and molybdenum and where $\mathrm{b}$ is a number from 1 to 3 and $\mathrm{c}$ is a number from 1 to 4 (e.g., $\mathrm{Co}_{3} \mathrm{O}_{4}$ ). Ferrites are the multiple oxides of ferric oxide represented by the formula $\mathrm{M}^{\prime} \mathrm{Fe}_{2} \mathrm{O}_{4}$, where $\mathrm{M}^{\prime}$ is at least one and as many as four different mono- or di-valent metals selected from nickel, zinc, lithium, molybdenum, manganese, cobalt, copper, strontium, barium, aluminum, gadolinium, and yttrium in 
which iron is in the +3 oxidation state. Naturally occurring ferrites include magnetite $\left(\mathrm{Fe}_{3} \mathrm{O}_{4}\right)$, hematite $\left(\mathrm{Fe}_{2} \mathrm{O}_{3}\right)$, jacobtite $\left(\mathrm{Fe}+\mathrm{Mn}_{3} \mathrm{O}_{4}\right)$, and others. Ferrites can also be prepared from metal oxides and iron oxides (e.g., $\mathrm{Ni}_{0.35} \mathrm{Zn}_{0.65} \mathrm{Fe}_{2} \mathrm{O}_{4}$, $2(\mathrm{CoO} \ldots \mathrm{Ba}) \ldots 8 \mathrm{Fe}_{2} \mathrm{O}_{3}, \quad \mathrm{CoFe}_{2} \mathrm{O}_{4}, \quad\left(\mathrm{Li}_{0.5} \mathrm{Fe}_{0.5}\right)_{0.9} \quad \mathrm{Zn}_{0.1} \mathrm{Fe}_{2} \mathrm{O}_{4}, \quad$ and $\quad\left(\mathrm{Li}_{0.5} \mathrm{Fe}_{0.5}\right)_{0.45}$ $\left.\mathrm{Ni}_{0.175} \mathrm{Zn}_{0.375} \mathrm{Fe}_{2} \mathrm{O}_{4}\right)$. The coating can be directly deposited by arc plasma or flame spraying on a suitable high-temperature alloy or be dispersed into an organic silicate, painted onto the substrate, and cured in air at $200^{\circ} \mathrm{C}$ to $300^{\circ} \mathrm{C}$. The absorptance remained greater than 0.90 even after exposure for $24 \mathrm{~h}$ to $700^{\circ} \mathrm{C}$ in air for solar-absorber coatings prepared using commercially available silicate binders, however the emittance stability was not reported [201]. The absorptance remained at 0.95 below 4 microns, after repeated high-temperature cycling (heated to $980^{\circ}-1060^{\circ} \mathrm{C}$ and cooled to ambient for $1 \mathrm{~h}$ ) for a high nickel-molybdenum alloy coated with a lithium-zinc ferrite [having the composition $\left.\left(\mathrm{Li}_{0.5} \mathrm{Fe}_{0.5}\right)_{0.9} \mathrm{Zn}_{0.1} \mathrm{Fe}_{2} \mathrm{O}_{4}\right]$ by an arc plasma spray system [201]. It has been calculated that at a solar concentration of 1000 , these metal oxide ferrite coatings are more efficient than a selective coating with an absorptance of 0.85 and an emittance of 0.1 up to $870^{\circ} \mathrm{C}$ [201]. At $680^{\circ} \mathrm{C}$, the metal oxide ferrite coating has net equivalent energy gains to a selective coating with $\alpha / \varepsilon\left(100^{\circ} \mathrm{C}\right)=0.9 / 0.1$. Even at solar concentrations of 40 , the metal oxide ferrite coating $\left[\alpha / \varepsilon\left(100^{\circ} \mathrm{C}\right)=0.9 / 0.9\right]$ is more efficient up to $257^{\circ} \mathrm{C}$ than a selective-coating with $\alpha / \varepsilon\left(100^{\circ} \mathrm{C}\right)=0.85 / 0.1$. However, increasing the selective coating absorptance to 0.9 , with emittance 0.1 , makes the selective coating $6 \%$ more efficient than a metal oxide ferrite coating at $260^{\circ} \mathrm{C}$ [201]. The high-temperature stability and concentrating solar power calculations show this coating could be of use to the CSP program. In addition, employing a selective solar-transmitting coating to lower the emittance could be useful.

4.2.c.4.2. Cermets and paints can be made from solid particle iron-doped alumina spheroids, Masterbeads, ${ }^{\circledR}$ manufactured by Norton Chemical Company, have good optical absorption properties over the solar insolation spectrum and favorable thermal and mechanical properties up to $1000^{\circ} \mathrm{C}$ [202]. Several candidate solid particulates were evaluated, including $\mathrm{Al}_{2} \mathrm{O}_{3}, \mathrm{SiC}, \mathrm{TiO}_{2}, \mathrm{ZrO}_{2}$, and $\mathrm{SiO}_{2}$, to be used in a solid particle central receiver, where a curtain of free-falling particles in the cavity absorbs the solar energy [202]. Only one particle met the necessary criteria. These were the Masterbeads ${ }^{\circledR}$ with an absorptance of $93 \%$, consisting of $86 \%$ alumina, $2 \%-4 \%$ silica, $6 \%-8 \%$ iron oxide, and $4 \%-5 \%$ titania formed into nearly spherical sintered bauxite particles by the Norton process [202]. Analogous to the paints (i.e., $\mathrm{FeMnCuO}_{\mathrm{x}}$ particles in the TSSS paint, $\mathrm{Ge}, \mathrm{Si}$, or $\mathrm{PbS}$ in high-temperature silicone binder, and $\mathrm{CuFeMnO}_{4}$ spinel powders in silica films), by distributing the solid particles or Masterbeads ${ }^{\circledR}$ in an IR-transmitting (i.e. non-emitting $\mathrm{ZrO}_{2}, \mathrm{TiO}_{2}$, or $\mathrm{CeO}_{2}$ ) binding layer, a Masterbeads ${ }^{\circledR}$ "paint" could be developed.

Recently, a silica sphere with a narrow particle distribution, and controlled uniform size and porosity has been produced by the sol-gel process using a patented multistage drying process developed by researchers at Shell [203]. Although this particle and process have been designed for other purposes, it may be a low-cost method to produce a solid particle for a solid particle absorber paint. Another method produces a spherical solid shell having a spherical space within which could be used in a solid particle paint. A polymer with high water absorption properties is swollen with water and is brought into contact with a powder to form a powder layer all over the surface of the 
swollen polymer particle [204]. This particle is then dried and fired. The powder can be clays, metals and their oxides, carbides, nitrides, borides, where the materials are chosen based on their solar selective and thermal properties [204]. Polymers coated with $\mathrm{ZrO}_{2}$ or AlN powders with their respective sintering aid mixtures were fired at $1650^{\circ} \mathrm{C}$ and $1820^{\circ} \mathrm{C}$, respectively [205]. The resulting sphere had high hardness strength, and temperature resistance (greater than their firing temperature).

Selective solar absorption properties can be provided by a cermet made with a bright flake-based metal (BFM) pigment [206]. The BFM comprises a core flake section with substantial rigidity whose uniaxial compressive strength is greater than the corresponding uniaxial tensile strength. The core flake section is formed of a central reflector layer (40 to $150 \mathrm{~nm}$ ) and dielectric support (10 to100 $\mathrm{nm}$ ) layers on opposing sides of the reflector layer [206]. A variety of outer-coating layers can be formed around the core flake sections, such as dielectric and absorber layers having thicknesses dependent on the desired optical characteristics of the pigment. The method to produce flake-type pigment particles has been improved such that flakes can be produced at high volume that are more durable, economical, and efficient than the previous method [207]. A BFM flake-cermet could be designed where both the flake and ceramic matrix are chosen for their selective and high-temperature properties.

Metal-coated nanoparticles or nanoshells can be made to absorb or reflect light at a specific wavelength in the visible and infrared spectrum[208]. The particles are homogeneous in size and comprise nonconducting inner layer that is surrounded by an electrically conducting outer layer [208]. The wavelength of maximum absorbance or scattering is determined by the ratio of the nonconducting layer to the outer conducting shell. The particles are synthesized by unique solution-phase methods that link clusters of conducting atoms, ions, or molecules to the nonconducting layer by linear molecules [208]. This step can be followed by growth of the metal onto clusters to form a coherent conducting shell that encapsulates the core. Mixtures of these nanoparticle compositions could be made into cermets or paints to absorb or reflect light across the spectrum.

It is not apparent from the literature, except for patent citations, that these selective-coating concepts have been put into practice; but depending on the materials selected and the properties of the solid particle and the binding layer, BFM-cermet, or metal nanoshell cluster, these could produce very high-temperature absorber coatings appropriate for CSP applications. In addition, the solid particle "paint" could be coated with a selective solar-transmitting coating to produce high-temperature absorber coatings useful for CSP applications

4.2.c.4.3. A refractory silicone Pyromark ${ }^{\circledR}$ series 2500 black paint, manufactured by Tempil Division of Big Three Industries, has been used on reentry vehicles for the space program and in receiver panels at Solar One in Barstow, CA. The paint has a high solar absorptance and emittance $\alpha / \varepsilon_{\mathrm{M}}\left(1000^{\circ} \mathrm{C}\right)=0.97 / 0.9$ [209]. A sprayed coating that has been vitrified at $540^{\circ} \mathrm{C}$ is capable of withstanding temperatures up to $1371^{\circ} \mathrm{C} \mathrm{[210]}$. The solar absorptance declines over time, if the vitrification temperature is below $540^{\circ} \mathrm{C}$ the solar absorptance declines over time [211]. As the paint is not solar selective, coating the paint with a selective solar-transmitting coating like a highly doped semiconductor (e.g., $\mathrm{SnO}_{2}: \mathrm{F}, \mathrm{SnO}_{2}: \mathrm{Sb}, \mathrm{In}_{2} \mathrm{SO}_{3}: \mathrm{Sn}$, and $\mathrm{ZnO}: \mathrm{Al}$ ) could be useful to produce hightemperature absorber coatings appropriate for CSP applications. 


\section{2.d. Surface Texturing}

Solar selectivity is exhibited for single-material surfaces with needle-like, dendrite, or porous microstructures on the same scale as the wavelength of the incident radiation. This geometrical selectivity is not very sensitive to severe environmental effects but may be damaged by surface contact or abrasion. A dense array of $W$ whiskers has $\alpha / \varepsilon\left(100^{\circ} \mathrm{C}\right)=0.98 />0.26$ for $\mathrm{T} \approx 550^{\circ} \mathrm{C}$ [212]. Sputter-etched metals, where titanium is used as a seed material, give good selectivity [212]. Textured copper is suitable for high temperature only in an evacuated tube, and attempts to texture aluminum failed because of sample overheating. Textured stainless-steel has $\alpha / \varepsilon\left(100^{\circ} \mathrm{C}\right)=0.93 \pm 0.02 / 0.22 \pm 0.02$ for $\mathrm{T}>440^{\circ} \mathrm{C}, \quad \varepsilon_{\mathrm{C}}\left(400^{\circ} \mathrm{C}\right)=0.24 \pm 0.02 \quad[213]$. Textured nickel is less stable, with $\alpha / \varepsilon\left(100^{\circ} \mathrm{C}\right)=0.92 \pm 0.02 / 0.09 \pm 0.02$ for $\mathrm{T}<300^{\circ} \mathrm{C}$. Smooth nickel is stable in air up to $440^{\circ} \mathrm{C}$, but textured nickel oxidizes when heated in air at $350^{\circ} \mathrm{C}$. Textured chrome has $\alpha / \varepsilon\left(100^{\circ} \mathrm{C}\right)=0.80-0.90 / 0.10-0.30$ for $\mathrm{T}<500^{\circ} \mathrm{C}$ [214]. Oxidation in air at high temperature caused an increase in $\alpha$ and $\varepsilon$ because of formation of chromium oxide. Other metals that are stable in air at high temperatures $\left(>600^{\circ} \mathrm{C}\right)$ include molybdenum, rhodium, platinum, tungsten, hafnium carbide, and gold [215]. The oxides of nickel and cobalt have been observed to be stable in air above $800^{\circ} \mathrm{C}$. Amorphous silicon, germanium, and GaAs have been textured with hydrogen peroxide or by reactive ion or sputtering etching to produce highly absorbing selective surfaces [215,216]. The textured microstructure can be protected from abrasion damage by protective coatings like the sol-gel coatings. A series of patents produces a composite selective coating of an organic and a dense discrete inorganic microstructure [216]. In the invention, the metal or inorganic semiconductor dendrites or whiskers (with a diameter from 1 to $5000 \mathrm{~nm}$ ) are encapsulated in a polymer, and then the composite structure is peeled from the substrate. This has the advantage of providing protection to the microstructure, but the disadvantage of lowering the temperature range to that of the polymer selected therefore making the composite selective coating unsuitable for CSP applications. Single-material surfaces may show selective properties if they have the proper roughness; however, protection from abrasion is a consideration. In general, single-material selective coatings are suitable for CSP applications. In addition, it is important to consider surface texture when designing the solar-selective properties of a material.

\section{Conclusion}

Many selective surfaces capable of operating at temperatures greater than $400^{\circ} \mathrm{C}$ have been developed and are cited in the literature. Ni-pigmented $\mathrm{Al}_{2} \mathrm{O}_{3}$, graded Ni$\mathrm{NiO}_{\mathrm{X}}$, black graded $\mathrm{Mo}$ or $\mathrm{W}-\mathrm{Al}_{2} \mathrm{O}_{3}$, and double SS-AlN cermets are commercially available, but most do not fulfill the requirements of the CSP program. For CSP parabolic trough applications, the spectrally selective surface should be stable to $500^{\circ} \mathrm{C}$, preferably in air, have a solar absorptance of 0.950-0.98 and a thermal emittance of 0.1 at $400^{\circ} \mathrm{C}$. High-temperature cermets and multiple layers of cermets have a high probability of meeting these goals. By using metals and dielectrics that are stable at higher temperatures (e.g., W, $\mathrm{Au}, \mathrm{Pd}, \mathrm{Pt}, \mathrm{ZrO}_{2}, \mathrm{MgO}, \mathrm{MnO}, \mathrm{SnO}_{\mathrm{x}}: \mathrm{F}, \mathrm{AlN}, \mathrm{AlON}, \mathrm{CeO}_{2}$, or $\mathrm{TiO}_{2}$ ) and incorporating multiple AR coatings and a multiple cermet coatings along with the appropriate texturing, materials could be improved or developed closer to the 
requirements for parabolic troughs. Several materials have the appropriate optical properties and should be durable at operating temperatures above $500^{\circ} \mathrm{C}$. However, it is usually unclear how realistic the cited results are. The research on a number of these promising materials has not been brought to fruition for a variety of reasons. It is sometimes uncertain if negative results are unreported and research then discontinued. In general, it easier to coat laboratory-scale flat coupons and the feasibility of producing the same coating at a manufacturing scale on tubes is typically not addressed.

With more research, multilayers and multiple layers of cermets of quasicrystals; $\mathrm{ZrB}_{2} ; \mathrm{ZrC}_{\mathrm{x}} \mathrm{N}_{\mathrm{y}} ; \mathrm{Ti}_{1-\mathrm{x}} \mathrm{Al}_{\mathrm{x}} \mathrm{N}$; $\mathrm{CuO}$ metallo-organic composites; $\mathrm{Cr}-\mathrm{SiO}, \mathrm{MnO}, \mathrm{Au}$ or Pt$\mathrm{TiO}_{2}, \mathrm{ZrO}_{2}, \mathrm{MgF}_{2}$ or $\mathrm{MgO}$ cermets; and "Black $\mathrm{Co}, \mathrm{Mo}$, and $\mathrm{W}$ " have the potential to meet the requirements as high-temperature selective surfaces and be suitable for CSP applications. Additionally, absorber coatings made with $\mathrm{M}_{\mathrm{b}} \mathrm{O}_{\mathrm{c}}+\mathrm{M}^{\prime} \mathrm{Fe}_{2} \mathrm{O}_{4}$, solid particle, BFM, and nanoshells could be of interest. Solar-selective coatings made with multiple cermet layers of quasicrystals or zirconium and titanium oxides and nitrides that incorporate surface texturing and multiple AR layers are likely to be successful and to meet the CSP optical and durability requirements. As a first step, optical modeling of the potential high-temperature selective surfaces should be performed to identify and select the coating thickness and composition of the most promising candidates. The most promising candidate(s) should be made and tested. The capability should be built to allow spectrally selective coatings to be exposed and measured at their operating temperatures and conditions for longer periods of time to determine the durability and thermal stability of the materials. In addition, a criterion needs to be developed for hightemperature selective surfaces applicable for concentrating applications. 


\section{References}

1. C. Seiffert, T. Eisenhammer, M. Lazarov, R. Sizmann, and R. Blessing, "Test facility for solar selective materials, ” ISES Solar World Congress, 2, 321 (1993).

2. A. Brunotte, M. Lazarov, and R. Sizmann, "Calorimetric measurements of the total hemispherical emittance of selective surfaces at high temperatures," A. Hugot-Le Goff, C. G. Granqvist, C. M. Lampert, eds., SPIE, 1727, 149 (1992).

3. Y. S. Touloukian, D. P. Dewitt, and R. S. Hernicz, Thermophysical Properties of Matter, Vol. 9, IFI/(Plenum Data Company, New York, 1972).

4. R. B. Pettit, "Total hemispherical emittance measurement apparatus for solar selective coatings," SAND-75-0079, Albuquerque, NM: Sandia National Laboratory, 1975.

5. S. Brunold, U. Frei, B. Carlsson, K. Möller, and,M. Köhl, “Accelerated life testing of solar absorber coatings: testing procedure and results," Solar Energy, 68, 4, 313 (2000).

6. W. S. Duff and L. Hamasaki, "Experimental evaluation of selective surfaces evacuated solar collectors," R. Campbell-Howe, T. Cortez, and B. Wilkins-Crowder, eds., Proceedings of American Solar Energy Conference, (American Solar Energy Society, Boulder, CO, 1998) p.345.

7. B. Carlsson, K. Möller, M. Köhl, U. Frei, and S. Brunold, "Qualification test procedure for solar absorber surface durability," Solar Energy Mater. \& Solar Cells, 61, 255 (2000).

8. H. Schellinger, M. Klank, M. Lazarov, O. Seibert, and R. Sizmann, "Monitoring the aging of solar absorbers," ISES Solar World Congress, 2, 315 (1993).

9. O. P. Agnihotri and B. K. Gupta, Solar Selective Surfaces, (Wiley-Interscience Pub, New York, NY, 1981), p. 91.

10. B. O. Seraphin, in Topics in Applied Physics, Vol. 31, B. O. Seraphin, ed., (Springer-Verlag, Berlin, Germany, 1979) p. 18.

11. G. Pellegrini, "Experimental methods for the preparation of selectively absorbing textured surfaces for photothermal solar conversion," Solar Energy Mater., 3, 391 (1980).

12. B. O. Seraphin and A. B. Meinel, in Optical Properties of Solids: New Developments, B. O. Seraphin, ed., (North Holland Publishing Co., Amsterdam, 1976) Chap. 17.

13. E. Randich and D. D. Allred, "Chemical vapor-deposited $\mathrm{ZrB}_{2}$ as a selective solar absorber," Thin Solid Films, 83, 393 (1981); E. Randich and R. B. Pettit, "Solar selective properties and high temperature stability of CVD ZrB 2 ," Solar Energy Mater., 5, 425 (1981).

14. H. Ehrenreich and B. O. Seraphin, Symposium on the Fundamental Optical Properties of Solids Relevant to Solar Energy Conversion, sponsored by National Science Foundation/Div. of Materials Research, Tuscon, AZ, 1975.

15. Y. S. Touloukian, D. P. Dewitt, and R. S. Hernicz, Thermophysical Properties of Matter, Vol. 9, IFI/(Plenum Data Company, New York, 1972).

16. R. B. Pettit, C. J. Brinker, and C. S. Ashley, "Sol-gel double-layer antireflection coatings for silicon solar cells," Solar Cells, 15, 267 (1985). 
17. A. F. Pereev and N. P. Frolova, "Antireflecting coatings for light-absorbing materials for the 0.4-5 $\mu \mathrm{m}$ spectral region," Sov. J. Opt. Technol., 41, 8, 453 (1974).

18. T. J. Moravec and R. A. Skogman, U.S. Patent No. 4,176,208, 27 November 1979.

19. O. P. Agnihotri and B. K. Gupta, Solar Selective Surfaces, (Wiley-Interscience Pub, New York, NY, 1981), p.126.

20. B. O. Seraphin, "Chemical vapor deposition of thin semiconductor films for solar energy conversion," Thin Solid Films, 39, 87 (1976); 57, 293 (1979).

21. Á. Andersson, O. Hunderi, and C. G. Granqvist, "Nickel pigmented anodic aluminum oxide for selective absorption of solar energy," J. Appl. Physics, 51, 754 (1980).

22. M. Born and E. Wolf, Principles of Optics, $6^{\text {th }}$ Ed. (Pergamon, Oxford, 1980).

23. R. N. Schmidt, K. C. Park, R. H. Torberg, and J. E. Jensen, "High Temperature Solar Coatings," Part I, AST-TDR-63-579, Honeywell Corporation, Hopkins, MN, 1963; R. N. Schmidt, K. C. Park, and J. E. Jensen, "High Temperature Solar Coatings," Part II, ML-TDR-64-250, Honeywell Corporation, Hopkins, MN, 1964.

24. G. A. Niklasson and C. G. Granqvist, in Materials Science for Solar Energy Conversion Systems, C. G. Granqvist, Ed. (Pergamon, Oxford, UK, 1991) Chap. 4.

25. C. A. Arancibia-Bulnes, C. A. Estrada, and J. C. Ruiz-Suárez, "Solar absorptance and thermal emittance of cermets with large particles," J. Phys. D: Appl. Phys., 33, 2489 (2000).

26. T. Tesfamichael, S. Andersson, T. Chibuye, and E. Wäckelgård, "Study of oxidation kinetics for metal-dielectric films using IR optical measurements," C. M. Lampert, C. G. Granqvist, M. Grätzel, S. K. Deb, eds., SPIE, 3138, 146 (1997).

27. R. Karmhag, T. Tesfamichael, G. A. Niklasson, E. Wäckelgård, and M. Nygren, "Oxidation kinetics of nickel solar absorber nanoparticles, "J. Phys. D: Appl. Phys., 34, 400 (2001).

28. T. Tesfamichael, Ph.D. Thesis, "Characterization of selective solar absorbers; experimental and theoretical modeling," (University Printers, Uppsala, Sweden, 2001) Chap. 4.

29. P. Gao, L.J. Meng, M. P. dos Santos, V. Teixeira, and M. Andritschky, "Study of $\mathrm{ZrO}_{2}-\mathrm{Y}_{2} \mathrm{O}_{3}$ films prepared by rf magnetron reactive sputtering," Thin Solid Films, 377-378, 32 (2000).

30. P. Gao, L.J. Meng, M. P. dos Santos, V. Teixeira, and M. Andritschky, "Characterization of $\mathrm{ZrO}_{2}$ films prepared by rf magnetron reactive sputtering at different $\mathrm{O}_{2}$ concentrations in the sputtering gases," Vacuum, 56, 143 (2000).

31. Q. -C. Zhang and D. R. Mills, "Very low-emittance solar selective surfaces using new film structures," J. Appl. Phys., 72, (7), 3013 (1992); Q. -C. Zhang, D. R. Mills, A. Monger, U.S. Patent No. 5,523,132, 4 June 1996.

32. M. Kussmaul, M. J. Mirtich, and A. Curren, "Ion beam treatment of potential space materials at the NASA Lewis Research Center," Surface \& Coatings Technol. 51, 299 (1992).

33. J. J. Cuomo, J.F. Ziegler, and J.M. Woodall, "A new concept for solar energy thermal conversion," Appl. Phys. Letters, 26, 10, 557 (1975). 
34. R. B. Bannerot, "Moderately concentrating (not focusing) solar energy collectors," S. L. Sargent, ed., Proceedings of the Workshop on Solar Collectors for Heating and Cooling of Buildings, (ASME, New York, NY, 1974) p. 306.

35. O. P. Agnihotri and B. K. Gupta, Solar Selective Surfaces, (Wiley-Interscience Pub, New York, NY, 1981), p.19.

36. H. W. Lehmann and R. Widmer, "Profile control by reactive sputter etching," J. Vac. Sci. Tecnol., 15, 2, 319 (1978).

37. M. H. Huang, S. Mao, H. Feick, H. Yan, W. Wu, H. Kind, E. Weber, R. Russo,and P. Yang, "Roomtemperature ultraviolet nanowire nanolasers," Science, 292, 5523 (June 8, 2001).

38. C. G. Granqvist, "Spectrally selective surfaces for heating and cooling applications," Series ed. R. F. Potter, Tutorial Texts in Optical Engineering, Vol. TT 1, (SPIE Optical Engineering Press, Bellingham, WA, 1989) p. 59.

39. D. A. Williams, T. A. Lappin, and J. A. Duffie, "Selective radiation properties of particulate coatings," J. Eng. Power, 85A, 213 (1963).

40. T. J. McMahon and D. L. Stierwalt, "Cost-effective PbS-Al selective solar-absorbing panel," SPIE, 68, 169 (1975); T. J. McMahon and A. K. Green, U.S. Patent No. 4,029,853, 14 June 1977.

41. O. P. Agnihotri and B. K. Gupta, Solar Selective Surfaces, (Wiley-Interscience Pub, New York, NY, 1981), p.124.

42. L. Aries and J-P, Traverse, U.S. Patent No. 4,405,414, 20 September 1983.

43. H. Tabor, "Selective radiation. I. Wavelength discrimination: A new approach to the harnessing of solar energy," Bull. Res. Council Isr. 5A, 119 (1956); H. Tabor, "Selective radiation. II. Wavefront discrimination: A new approach to the harnessing of solar energy," Bull. Res. Council Isr. 5A, 129 (1956).

44. W. F. Bogaerts and C. M. Lampert, "Materials for photothermal solar energy conversion," J. Mat. Sci. 18, 2847 (1983).

45. M. Koltun, G. Gukhman, and A. Gavrilina, "Stable selective coating "black nickel" for solar collector surfaces," SEM 33, 41 (1994).

46. E. Wäckelgård, "Characterization of black nickel solar absorber coatings electroplated in a nickel chlorine aqueous solution," SEM, 56, 35 (1998).

47. S. N. Patel, O. T. Inal, A. J. Singh, and A. Schrer, "Optimization and thermal degradation study of black nickel solar collector coatings," Solar Energy Mater., 11, 381 (1985).

48. J.J Mason and T.A. Brendel, "Maxorb - a new selective surface on nickel," SPIE, 324, 139 (1982).

49. R. Mahoney, Internal email, SunLab, Albuquerque, NM, 18 October, 2001.

50. D. D. Allerd, J. M. Reyes, and J. A. Piontkowski, U.S. Patent No. 4,582,764, 15 April 1986.

51. P. Richharia and K. L. Chopra, "Stability investigations of a chemically converted textured black copper selective surface," Solar Energy Mater., 19, 365 (1989). 
52. P. Richharia, "Textured black copper solar selective absorber coatings," Renewable Energy: Technology and the Environment, V2 Solar Thermal Technology, A. A. M. Sayigh, ed., (Pergamon Press, Oxford, UK, 1992), p. 1035

53. G. E. McDonald, "Spectral reflectance properties of black chrome for solar collector use," Solar Energy, 17, 119 (1975).

54. P. M. Driver, "An electrochemical approach to the characterization of black chrome selective surfaces,” SEM, 4, 1799 (1981).

55. A. Ignatiev, P. O'Neill, and G. Zajac, "The surface microstructure - optical properties relationship in solar absorbers: black chrome," SEM, 1, 69 (1979).

56. G. B. Smith, R. C. McPhedran, and G. H. Derrick, "Surface structure and the optical properties of black chrome," Appl. Phys. A, 36, 193 (1985).

57. J. N. Sweet, R. B. Pettit, and M. B. Chamberlain, "Optical modeling and aging characteristics of thermally stable black chrome," SEM, 10, 251 (1984).

58. C. M. Lampert, "A chemical, structural, and optical characterization of a black chrome solar selective absorber,” Ph.D. Thesis, Berkeley, CA: Lawrence Berkeley Laboratory, 1980.

59. P. H. Holloway, K. Shanker, R. B. Pettit, and R. R. Sowell, "Oxidation of electrodeposited black chrome selective solar absorber films," SAND-80-1045. Albuquerque, NM: Sandia National Laboratory, 1980.

60. A. Muehlratzer, G. P. Goerler, E. Erben, and H. Zeilinger, "Selection of a black chrome bath for continuous tube-plating and the properties of the coating deposited from it," Solar Energy, 63, 125 (2000).

61. G. Zajac, G. B. Smith, and A. Ignatiev, "Refinement of solar absorbing black chrome microstructure and its relationship to optical degradation mechanisms," J. Appl. Physics, 51, 10, 5544 (1980).

62. K. D. Lee, W. C. Jung, and J. H. Kim, "Thermal degradation of black chrome coatings," Solar Energy Mater. \& Solar Cells, 60, 295 (2000).

63. R. B. Pettit and R. R. Sowell, "Black chrome solar selective coating," SAND-80-1480. Albuquerque, NM: Sandia National Laboratory, 1980.

64. C. M. Lampert, "Metallurgical analysis and high temperature degradation of the black chrome solar selective absorber," Thin Solid Films, 77, 1, 73 (1980).

65. C. M. Lampert and J. Washburn, "Microstructure and optical properties of black chrome before and after exposure to high temperatures," P.J. Call, (ed.) Proc. $2^{\text {nd }}$ Annual Conf on Absorber Surfaces for Solar Receivers, SERI/TP-49-182, Golden, CO: Solar Energy Research Institute, 19 (1979).

66. G. B. Smith and A. Ignatiev, "Black chromium-molybdenum: a new stable solar absorber," Solar Energy Mat., 4, 119 (1981).

67. S. Süzer, F. Kadirgan, H. M. Söhmen, A. J. Wetherilt, and İ. E. Türe, "Spectroscopic characterization of $\mathrm{Al}_{2} \mathrm{O}_{3}$-Ni selective absorbers for solar collectors," Solar Energy Mater. \& Solar Cells, 52, 55 (1998).

68. T. Tesfamichael and E. Wäckelgård, "Angular solar absorptance and incident angle modifier of selective absorbers for solar thermal collectors," Solar Energy Mater., 51, 171 (1998). 
69. T. Möller and D. Hönicke, "Solar selective properties of electrodeposited thin layers of aluminum," Solar Energy Mater. \& Solar Cells, 54, 397 (1998).

70. F. Kadirgan, E. Wäckelgård, and M. Söhmen, "Electrochemical characterization of $\mathrm{Al}_{2} \mathrm{O}_{3}$-Ni thin film selective surface on aluminum," Turk. J. Chem, 23, 381 (1999).

71. L. Li, "AC anodization of aluminum, electrodeposition of nickel and optical property examination," Solar Energy Mater. \& Solar Cells, 64, 279 (2000).

72. J. Salmi, J.-P. Bonino, and R. S. Bes, "Nickel pigmented anodized aluminum as solar selective absorbers," J. Mat. Sci., 35, 1347 (2000).

73. T. Möller, Th. Schwarz, and D. Hönicke, "Solar selective properties of electrolytically formed thin layers on aluminum," J. Solar Energy Eng., 122, 101 (2000).

74. N. M. Nahar, G.H. Mo, and A. Ignatiev, "Development of an $\mathrm{Al}_{2} \mathrm{O}_{3}$-Co selective absorber for solar collectors," Thin Solid Films, 172, 19 (1989).

75. T. Tesfamichael, W. E. Vargas, E. Wäckelgård, and G. A. Niklasson, "Optical properties of silicon pigmented alumina films," J. Appl. Phys., 82, 7, 3508 (1997).

76. T. Tesfamichael, W. E. Vargas, E. Wäckelgård, and G. A. Niklasson, "A feasibility study of integrally colored Al-Si as a solar selective absorber," Solar Energy Mater. \& Solar Cells, 55, 251 (1998).

77. T. Tesfamichael, E. Wäckelgård, and A. Helgesson, "Impact of solar absorptance on collector performance investigated by dynamic collector testing and optical angular characterization of solar absorbers," North Sun '99: Proceedings of the 8th International Biannual Conference on Solar Energy in High Latitudes, incorporating the Proceedings of the 25th Annual Conference of the Solar Energy Society of Canada, (Solar Energy Society of Canada Inc., Ottawa, ON (Canada), 1999) p. 146.

78. T. Tesfamichael and E. Wäckelgård, "Angular solar absorptance of absorbers used in solar thermal collectors," Appl. Optics, 38, 19, 4189 (1999).

79. A. Othonos, M. Nestoros, D. Palmerio, C. Christofides, R. S. Bes, and J. P Traverse, "Photothermal radiometry on nickel (pigmented aluminum oxide) selective surface absorbing surface coatings," Solar Energy Mater. \& Solar Cells, 51, 171 (1998).

80. R. Karnhag, G. A. Niklasson, and M. Nygren, "Oxidation kinetics of small nickel particles," J. Appl. Phys., 85, 2, 1186 (1999).

81. L. Li, "Formation of ultrafine metal particles and metal oxide precursor on anodized Al by electrolysis deposition,” J. Mater. Sci. Technol., 16, 1, 50 (2000).

82. R. Karnhag, T. Tesfamichael, E. Wäckelgård, G. A. Niklasson, and M. Nygren, "Oxidation kinetics of nickel particles: comparison between free particles and particles in an oxide matrix," Solar Energy, 68, 4, $329(2000)$.

83. T. Tesfamichael and A. Roos, "Treatment of antireflection on tin oxide coated anodized aluminum selective absorber surface," Solar Energy Mater. \& Solar Cells, 54, 213 (1998).

84. H. S. Varol and A. Hinsch, " $\mathrm{SnO}_{2}: \mathrm{Sb}$ dip coated films on anodized aluminum selective absorber plates," Solar Energy Mater. \& Solar Cells, 40, 273 (1996).

85. T. Tesfamichael and E. Wäckelgård, "Angular solar absorptance and incident angle modifier of selective absorbers for solar thermal collectors," Solar Energy, 68, 4, 335, (2000). 
86. B. Orel, Z. C. Orel, R. Jerman, and I. Radoczy, "Coil-coating paints for solar collector panels - II. FTIR spectroscopic investigations," Solar \& Wind Tecnol., 7, 6, 713 (1990).

87. B. Orel and Z. C. Orel, "FTIR spectroscopic investigations and the thermal stability of thickness sensitive spectrally selective (TSSS) paint coatings," Solar Energy Mater., 22, 259 (1991).

88. Z. C. Orel and M. K. Gunde, "Spectrally selective paint coatings: Preparation and characterization," Solar Energy Mater. \& Solar Cells, 68, 337 (2001).

89. D. M. Mattox and R. R. Sowell, "High absorptivity solar absorbing coatings," J. Vac. Sci. Technol., 11, 4, 793 (1974).

90. R. B. Pettit and R. R. Sowell, "Solar absorptance and emittance properties of several solar coatings," $J$. Vac. Sci. Technol., 13, 2, 596 (1976).

91. L. Kaluža, A. Šurca-Vuk, B. Orel, G. Dražič, and P. Pelicon, "Structural and IR spectroscopic analysis of sol-gel processed $\mathrm{CuFeMnO}_{4}$ /silica films for solar absorbers," J. Sol-Gel Sci \& Technol., 20, 61 (2001).

92. Y. Cao and X. Hu, "Absorbing film on metal for solar selective surface," Thin Solid Films, 375, 155 (2000).

93. Y. Cao, J. Tian, and X. Hu, "Ni-Cr selective surface based on polyamide substrate," Thin Solid Films, 365, 49 (2000).

94. B. Karlsson and T. Karlsson, "Optical properties of carbon for photo-thermal conversion," UPTEC, 8195R (1981).

95. G. L. Harding and S. Craig, "Composition and degradation of graded metal-carbon solar selective absorbing surfaces," Solar Energy Mater., 4, 413 (1981).

96. F. Milde, M. Dimer, P. Gantenbein, C. Hecht, D. Pavic, and D. Schulze, "Industrial scale manufacture of solar absorbent multilayers by MF-pulsed plasma technology," Proceedings of the 1999 42nd Annual Technical Conference, (Soc. Vacuum Coaters, Albuquerque, NM, 1999) p. 163-168.

97. R. Gampp, P. Glantenbein, Y. Kuster, P. Reimann, R. Steiner, P. Oelhafen, S. Brunold, U. Frei, A. Gombert, R. Joerger, W. Graf, and M. Köhl, "Characterization of a-C:H/W and a-C:H/Cr solar selective absorber," SPIE, 2255, 92 (1994).

98. A. Schüler, J. Geng, P. Oelhafen, S. Brunold, P. Gantenbein, and U. Frei, “Application of titanium containing hydrogenated carbon films (a-C:H/Ti) as optical selective solar absorber coatings," Solar Energy Mater. \& Solar Cells, 60, 295 (2000).

99. R. Joerger, T. Klaus, E. Olsson, and C. G. Granqvist, "Spectrally selective solar absorbing surface coatings prepared by a biomimetic technique," SPIE, 3789, 2 (1999).

100. R. Joerger, T. Klaus, and C. G. Granqvist, "Biologically produced silver-carbon composite materials for optically functional thin-film coatings," Adv. Mater., 12, 6, 407 (2000).

101.T. J. Beveridge and R. J. Doyle, Metal Ions and Bacteria, (Wiley, NY, 1989); G. Southam and T. J. Beveridge, Geochim Cosmochim. Acta, 60, 4369 (1996); D. Fortin and T. J. Beveridge, "From Biology to Biotechnology and Medical Applications," Biomineralization,. E. Baeuerlein, ed., (WileyVCH, Weinheim, 2000).

102.T.J. Beveridge and R.G.E. Murray, J. Bacterial, 141, 876 (1980). 
103.M. Sastry and R. Kumar, "Bioreduction of $\mathrm{AuCl}_{4}{ }^{-}$Ions by the Fungus Verticillium sp. and surface trapping of the gold nanoparticles formed," Angew. Chem. Int. Ed., 40, 3585 (2001).

104.M. Lazarov, R. Sizmann, and U. Frei, "Optimization of $\mathrm{SiO}_{2}-\mathrm{TiN}_{\mathrm{x}} \mathrm{O}_{\mathrm{y}}-\mathrm{Cu}$ interference absorbers: numerical and experimental results," SPIE, 2017, 345 (1993).

105.H. Schellinger, M. Lazarov, W. Assmann, B. Bauer, and C. Steinhausen, "Improved selective properties of $\mathrm{SiO}_{2}-\mathrm{TiN}_{\mathrm{x}} \mathrm{O}_{\mathrm{y}}$ - $\mathrm{Al}$ tandem absorbers effected by tempering," SPIE, 2255, 172 (1994).

106.H. Schellinger, M. Lazarov, H. Klank, and R. Sizmann, "Thermal and chemical metallic-dielectric transitions of $\mathrm{TiN}_{\mathrm{x}} \mathrm{O}_{\mathrm{y}}-\mathrm{Cu}$ absorber tandems," SPIE, 2017, 366 (1993).

107.J. B. Metson, K. E. Prince, A. Bittar, and L. J. Tornquist, "XPS and SIMS characterization of $\mathrm{TiN}_{\mathrm{x}} \mathrm{O}_{\mathrm{y}}$ solar absorber films," Proceedings of the 11th National School and Conference of the Australian Xray, Melbourne, Australia, 180 (1999).

108.M. R. Jacobson, "State-of-the-art review of optical materials relevant to CSP technologies," NREL Strategic Plan for Solar Optical Materials $R \& D$, Golden, CO: National Renewable Energy Laboratory, 2000.

109.A. Bittar, D. Cochrane, S. Caughley, and I. Vickeridge, "Study of $\mathrm{TiN}_{\mathrm{x}} \mathrm{O}_{\mathrm{y}}$ thin film selective surfaces produced by ion assisted deposition," J. Vac. Sci. Technol., 15, 2, 223 (1997).

110.R. E. Hahn and B. O. Seraphin, "Sputtered metal carbide solar-selective absorbing surfaces," J. Vac. Sci. Technol., 12, 905 (1975).

111.G. L. Harding, "Sputtered metal silicide solar selective absorbing surfaces," J. Vac. Sci. Technol., 15, 65 (1978).

112.G. L. Harding, "Sputtered metal carbide solar-selective absorbing surfaces," J. Vac. Sci. Technol., 13, 1070 (1976).

113.I. T. Ritchie, "The structure of reactively sputtered metal carbide and metal silicide solar selective absorbers," Thin Solid Films, 72, 65 (1980).

114.W. A. Brainard and D. R. Wheeler, U.S. Patent No. 4,336,117, 22 June 1982; W. A. Brainard and D. R. Wheeler, U.S. Patent No. 4,341,843, 27 July 1982.

115.E. Wäckelgård and G. Hultmark, "Industrially sputtered solar absorber surface," Solar Energy Mater. \& Solar Cells, 54, 165 (1998); G. Hultmark, U.S. Patent No. 6,171,458, 9 January 2001.

116.M. Adsten, R. Joerger, K. Järrendahl, and E. Wäckelgård, "Optical characterization of industrially sputtered nickel-nickel oxide solar selective surface," Solar Energy, 68, 4, 325 (2000).

117.H. S. Gurev and B. O. Seraphin, "Progress in chemical vapor deposition of thin silicon films for solar energy conversion," Proc $5^{\text {th }}$ Intl. Conf. CVD, J. M. Blocher Jr., H. E. Hinterman, and L. H. Hall, eds., (The Electrochemical Soc. Inc, Buckinghamshire, England, 1975) p. 667.; B. O. Seraphin, "Chemical vapor deposition of thin semiconductor films for solar energy conversion," Thin Solid Films, 39, 87 (1976).

118.A. E. B. Presland, G. L. Price, and D. L. Trimm, "Hillock formation by surface diffusion on thin silver films," Surf. Sci., 29, 424, (1972); A. E. B. Presland, G. L. Price, and D. L. Trimm "The role of microstructure and surface energy in hole growth and island formation in thin silver films," Surf. Sci., 29, 435 (1972). 
119.O. P. Agnihotri and B. K. Gupta, Solar Selective Surfaces, (Wiley-Interscience Pub, New York, NY, 1981), p. 128.

120.R. W. Griffith, "Amorphous semiconductors in photovoltaic and solar thermal conversion," Sun Proceedings Intl, Solar Energy Society Congress, 638 (1978).

121.A. Donnadieu and B. O. Seraphin, "Optical performance of absorber-reflector combinations for photothermal solar energy conversion," J. Opt. Sci. Am., 68, 292 (1978); B. O. Seraphin, "Chemical vapor deposition of spectrally selective surfaces for high temperature photothermal conversion," Thin Solid Films, 57, 293 (1979).

122.M. Okuyama, K. Saji, T. Adachi, H. Okamoto, and Y. Hamakawa, "Selective absorber using glowdischarge for amorphous silicon for solar photothermal conversion," Solar Energy Mat., 3, 405 (1980).

123.D. D. Allerd, J. M. Reyes, and J. A. Piontkowski, U.S. Patent No. 4,582,764, 15 April 1986.

124.O. A. Panchenko, A. A. Goncharov, and B. V. Stetsenko, "The spectral selective absorber layers created by the DC reactive magnetron sputtering," Probl. At. Sci. Technol., Ser.: Plasma Phys., 132, 16,253 (1999).

125.O. A. Panchenko, A. A. Goncharov, and B. V. Stetsenko, "Selective absorber systems based on Sn, Cr oxides, and Al nitride," Int. Conf. Coat. Glass, High-Perform. Coat. Transparent Syst. Large-Area High-Vol. Appl., Pulker, H. K., Schmidt, H., Aegerter. M. A., (Elsevier Science, Amsterdam, 1999) p. 287.

126.M. Mwamburi and E. Wäckelgård, "Doped tin oxide coated aluminum solar selective reflector systems," Solar Energy, 68, 4, 371 (2000).

127.E. M. Griest, U.S. Patent 4,286,009, 25 August 1981.

128.H. C. Hottel and T. A. Unger, "The properties of copper oxide-aluminum black surface absorber of solar energy," Solar Energy, 3, 3, 10 (1959).

129.P. Kokoropoulus, E. Salam, and F. Daniels, "Selective radiation coatings: Preparation and high temperature stability," Solar Energy, 3, 4, 19 (1959).

130.Md. Kamrul and A. Khan, "Copper oxide coatings for use in a linear solar Fresnel reflective concentrating collector," Renewable Energy, 17, 603 (1999).

131.R. J. Farrauto, J. C. Williams, and H. Myers, U.S. Patent 4,321,300, 23 March 1982.

132.K. Aykan, R. J. Farrauto, C. F. Jefferson, and R. D. Lanam, U.S. Patent 4,416,916, 22 November 1983.

133.C. F. Jefferson, U. S. Patent 4,437,455, 20 March 1984.

134.P. M. Martin, J. W. Johnston, and W. D. Bennet, "Multilayer coatings and optical materials for tuned infrared emittance and thermal coating," Mat. Res. Soc. Symp. Proc., 555, 3 (1999).

135.E. Randich and R. B. Pettit, "Solar selective properties and high temperature stability of CVD $\mathrm{ZrB}_{2}$," Solar Energy Mater., 5, 425 (1981).

136.T. S. Sathiaraj, R. Thangarj, A. A. Sharbaty, M. Bhatnagar, and O. P. Agnihotri, "Ni- $\mathrm{Al}_{2} \mathrm{O}_{3}$ selective cermet coatings for photothermal conversion up to 500 ${ }^{\circ}$," Thin Solid Films, 190, 241 (1990). 
137.M. Lanxner and Z. Elgat, "Solar selective absorber coating for high service temperatures, produced by plasma sputtering," Proc. Photo-Opt. Instrum. Engr. 1272, 240 (1990).

138.R. E. Peterson and J. W. Ramsey, "Thin coatings in solar-thermal power systems," J. Vac. Sci. Technol. A, 12, 1, 174 (1975).

139.R. Mahoney, "HCE issues; cermet preliminary results, optical properties, and construction forum 2001," Presentation at Solar Forum 2001, Solar Energy: The Power to Choose, April 21-25, Washington, DC.; R. Mahoney, Internal email, SunLab, Albuquerque, NM, 18 October, 2001.

140.A. Berghaus, A. Djahanbakhsh, and L. K. Thomas, "Characterization of CVD-tungsten-alumina cermets for high-temperature selective absorbers," Solar Energy Mater. \& Solar Cells, 54, 19 (1998).

141.P. R. C. Goard, "Application of hemispherical surface pyrometers to the measurement of the emissivity of platinum (a low-emissivity material)," J. Sci. Instrum., 43, 256 (1966).

142.H. G. Craighead, R. Bartynski, R. A. Buhrman, L. Wojcik, and A. J. Stevens, "Metal/insulator composite selective absorbers," Solar Energy Mater., 1, 105 (1979).

143.J. A. Thornton and J. A. Lamb, "Evaluation of cermet selective absorber coatings deposited by vacuum sputtering,” SERI Final Subcontract Report SERI/STR-255-3040, Golden, CO: Solar Energy Research Institute, March 1987.

144.H. G. Craighead, R. E. Howard, J. E. Sweeney, and R. A. Buhrman "Graded-index Pt- $\mathrm{Al}_{2} \mathrm{O}_{3}$ composite solar absorbers," Appl. Phys. Lett., 39, 1, 29 (1981).

145.G. McDonald, "A preliminary study of a solar selective coating system using black cobalt oxide for high temperature solar collectors," Thin Solid Films, 72, 83 (1980).

146.G. B. Smith, A. Ignatiev, and G. Zajac, "Solar selective black cobalt: preparation, structure, and thermal stability," J. Appl. Phys., 51(8), 4186 (1980).

147.K. Chidambaram, L. K. Malhotra, and K. L. Chopra, "Spray-pyrolysed cobalt black as a high temperature selective absorber," Thin Solid Films, 97, 365 (1982).

148.C. Choudhury and H. K. Sehgal, "High temperature degradation in cobalt oxide selective absorber," Solar Energy, 30, 3, 291 (1983).

149.D. F. Shepard and R. J. Fenolia, U.S. Patent 4,904,353, 27 February 1990.

150.F. Kadirgan and M. Söhmen, "Development of black cobalt selective absorber on copper on solar collectors," Turk. J. Chem., 23, 345 (1999).

151.S. Süzer, F. Kadirgan, and H. M. Söhmen, "XPS characterization of Co and Cr pigmented copper solar absorbers," Solar Energy Mater. \& Solar Cells, 56, 183 (1999).

152.N. Karuppiah and S. John, "Characterization of electrodeposited nickel-cobalt based selective coatings for solar thermal energy conversion," Bulletin of Electrochemistry, 16, 2, 71 (2000).

153.K. J. Cathro, "Preparation of cobalt-oxide-based selective surfaces by a dip-coating process," Solar Energy Mater., 9, 433 (1984).

154.E. Barrera, T. Viveros, A. Montoya, and M. Ruiz, "Titanium-tin oxide protective films on a black cobalt photothermal absorber," Solar Energy Mater. \& Solar Cells, 57, 127 (1999). 
155.K. A. Gesheva, E. E. Chain, and B. O. Seraphin, "Black molybdenum photothermal converter layers deposited by pyrolytic hydrogen reduction of $\mathrm{MoO}_{2} \mathrm{Cl}_{2}$," Solar Energy Mater., 3, 415 (1980).

156.K. A. Gesheva, D. S. Gogova, and G. Stoyanov, "Black tungsten selective optical coating for photothermal solar energy conversion," J. Phys. III France, 2, 1453 (1992).

157.G. E. Carver, H. S. Gurev, and B. O. Seraphin, "Passivating CVD molybdenum films against infrared reflection losses caused by oxidation," J. Electrochem Soc., 125, 7, 1138 (1978).

158.D. S. Gogova, "Optical and structural characterization of tungsten-based CVD metal oxide coatings," Mat. Lett., 30, 109 (1997).

159.L. K. Thomas, A. Berghaus, and M. R. Jacobson, "Preparation of $\mathrm{W}-\mathrm{WO}_{\mathrm{x}}$-cermets for solar selective absorbers," SPIE, 2255, 119 (1994).

160.O. A. Harizanov, K. A. Gesheva, and P. L. Stefchev, "Sol-gel and CVD-metal oxide coatings for solar utilization," Ceram. Inter., 22, 91 (1996).

161.Y. Yin and R. E. Collins, "Optimization and analysis of solar selective surfaces with continuous and multilayer profiles," J. Appl. Phys., 77, 12, 6485 (1995).

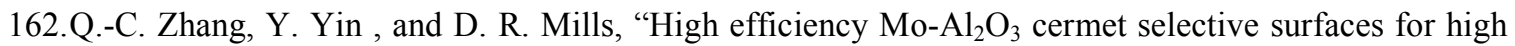
temperature applications," Solar Energy Mater. \& Solar Cells, 40, 45 (1996).

163.Q.-C. Zhang, "Solar selective coatings for solar thermal electricity," Aust. \& New Zeal. Physist, 35, 1, 16 (1998).

164.Q.-C. Zhang, "Direct current magnetron sputtered W-AlN cermet solar absorber films," J. Vac. Sci. Technol. A, 15, 6, 2842 (1997).

165.Q.-C. Zhang, "Metal-AlN cermet solar selective coatings deposited by direct current magnetron sputtering technology," J. Phys. D: Appl. Phys., 31, 355 (1998).

166.Q.-C. Zhang, K. Zhao, B.-C. Zhang, L.-F. Wang, Z.-L. Shen, Z.-J. Zhou, D.-Q. Lu, D.-L. Xie, and B.-F. Li, "New cermet solar coatings for solar thermal electricity applications," Solar Energy, 64, 1-3, 109 (1998).

167.Q.-C. Zhang, "Stainless-steel—AIN cermet solar selective surfaces deposited by direct current magnetron sputtering technology," Solar Energy Mater. \& Solar Cells, 52, 95 (1998).

168.Q.-C. Zhang, K. Zhao, B.-C. Zhang, L.-F. Wang, Z.-L. Shen, D.-Q. Lu, D.-L. Xie, Z.-J. Zhou, and B.-F. Li, "A cylindrical magnetron sputtering system for depositing metal-aluminum nitride cermet solar coatings onto batches of tubes," J. Vac. Sci. Technol. A, 16, 2, 628 (1998).

169.Q.-C. Zhang, "Recent progress in high-temperature solar selective coatings," Solar Energy Mater. \& Solar Cells, 62, 63 (2000).

170.B. Lee, "The progress and prospect of middle/high temperatures evacuated tubular solar collector," Renewable Energy, 24, 539 (2001).

171.Q.-C. Zhang, "High efficiency Al-N cermet solar coatings with double cermet layer film structures," $J$. Phys. D: Appl. Phys., 32, 1938 (1999).

172.M. Farooq, A. A. Green, and M. G. Hutchins, "Simplified composite multilayer selective solar absorber surfaces: a comparison of $\mathrm{V}: \mathrm{Al}_{2} \mathrm{O}_{3}$ and $\mathrm{Ni}: \mathrm{SiO}_{2}$ coatings," Towards a Renewable Future: 
Silver Jubilee Conference. Conference C73. Proceedings. N. Pearsall, M. G. Hutchins, C. Buckle, eds., (Solar Energy Society, Oxford, UK, 1999), p. 297.

173.M. Farooq, A. A. Green, and M. G. Hutchins, "High performance sputtered $\mathrm{Ni}: \mathrm{SiO}_{2}$ composite selective solar absorber surfaces," Solar Energy Mater. \& Solar Cells, 54, 67 (1998).

174.M. Djahanbakhsh, J. Eldring, B. Kluge, and L. K. Thomas, "Ageing of solar selective Cr-SiOabsorbers," SPIE, 2255, 127 (1994).

175.T. Eisenhammer, "Quasicrystal films: numerical optimization as a solar selective absorber," Thin Solid Films, 270, 1 (1995).

176.A. Haugender, T. Eisenhammer, A. Mahr, J. Schneider, and M. Wendel, "Oxidation of quasicrystalline and crystalline AlCuFe thin films in air," Thin Solid Films, 307, 120, (1997).

177.T. Eisenhammer, H. Nolte, W. Assmann, and J. M. Dubois," "Preparation and properties of solar selective absorbers based on $\mathrm{AlCuFe}$ and $\mathrm{AlCuFeCr}$ thin films: industrial aspects," Mat. Res. Soc. Symp. Proc., 553, 435 (1999).

178.T. Eisenhammer, H. Schellinger, and M. Lazarov, U.S. Patent No. 5,912,045, 15 June, 1999.

179.P. C. Gibbons and K. F. Kelton, "Chap. 12. Toward Industrial Applications," Z. Stadnik, ed., Physical Properties of Quasicrystals, Springer Series in Solid-State Sciences, (Springer, New York, 1999) p. 403.

180.Á. Morales and J. I. Ajona, "Durability, performance and scalability of sol-gel front surface mirrors and selective absorbers," J. Phys. IV France, 9, 3, 513 (1999).

181.J. C. C. Fan and P. M. Zavraky, "Selective black absorbers using MgO/Au cermet films," App. Phys. Lett., 29, 478 (1977); J. C. C. Fan, U.S. Patent No. 4,312,915, 26 January 1982; J. C. C. Fan, U.S. Patent No. 4,442,166, 10 April 1984.

182.R. N. Schmidt and K. C. Park, "High-temperature space-stable selective solar absorber coatings," Applied Optics, 4, 8, 917 (1965).

183.P. H. Lissberger and R. G. Nelson, "Optical properties of thin film Au-MgF $\mathrm{M}_{2}$ cermets," Thin Solid Films, 21, 159 (1974).

184.J. C. C. Fan and F. J. Bachner, "Transparent heat mirrors for solar-energy applications," Applied Optics, 15, 4, 1012 (1976).

185.W. J. Kaiser and E. M. Logothetis, U.S. Patent No. 4,591,417, 27 May 1986.

186.A. M. Gerber, U.S. Patent No. 4,855,984, 8 August 1989.

187.J. J. Hanak, U.S. Patent No. 4,162,505, 24 July 1979.

188.T. Adachi and T. Arakawa, U.S. Patent No. 4,381,233, 26 April 1983.

189.J. Dickson, "Thin film coatings from metallo-organic solutions," Proc. DOE/DS7 Thermal Power Systems Workshop on Selective Absorber Coatings, P. Call, ed., SERI TP-31-061, Golden, CO: Solar Energy Research Institute, 1977, p. 359.

190.R. Blickensderfer, "Metal oxycabonitride solar absorbers," Proc. DOE/DS7 Thermal Power Systems Workshop on Selective absorber coatings, P. Call, ed,. SERI TP-31-061, Golden, CO: Solar Energy Research Institute, 1977, p. 371; R. Blickensderfer, D. K. Deardorff, and R. L. Lincoln, "Spectral 
reflectance of $\mathrm{TiN}_{\mathrm{x}}$ and $\mathrm{ZrN}_{\mathrm{x}}$ films as selective solar absorbers," Solar Energy, 19, 429 (1977); R. Blickensderfer, U.S. Patent No. 4,098,956, 4 July 1978.

191.K. D. Masterson and B. O Seraphin, "Investigation of high temperature performance of thin film, solar-thermal energy converters," Arizona Univ. Optical Science Center, Tuscon, AZ, (1976).

192.D. M. Mattox and R. R. Sowell, "A survey of selective solar absorbers and their limitations," Journal de Physique, C1, n1, 42, (1981).

193.H. Ihara, S. Ebiswa, and A. Itoh, "Solar-selective surface of zirconium carbide film," Proc. 7th Int. Vac. Cong. and 3rd Int. Conf. on Solid Surfaces, R. Dobrozensky, F. Ruderman, F. P. Viehbock, and A. Breth, eds., (1977) p. 1813.

194.Y. Noguchi, K. Naka, A. Isao, K. Nakumura, S. Sawada, T. Tani, and S. Gonda, "Fabrication of $\mathrm{ZrC}_{\mathrm{x}} / \mathrm{Zr}$ and $\mathrm{Cr}-\mathrm{CrO}_{\mathrm{x}}$ films for practical solar selective absorption systems," SPIE, 324, 124 (1982).

195.M. P. Lazarov and I. V. Mayer, U.S. Patent No. 5,670,248, 23 September 1997; M. P. Lazarov and I. V. Mayer, U S. Patent No. 5,776,556, 7 July 1998.

196.A. H. Lettington and C. Smith, U.S. Patent No. 5,723,207, 3 March 1998.

197.C. Z. Deng, K. C. Tsai, and D. Ghantous, U.S. Patent No. 5,980, 977, 9 November 1999.

198.R. Wuhrer, W. Y. Yeung, M. R. Phillips, and G. McCredie, "Study on d.c. magnetron sputter deposition of titanium aluminum nitride thin films: effect of aluminum content on coating," Thin Solid Films, 290-291, 339 (1996).

199.G. B. Smith, P. D. Swift, and A. Bendavid, "TiN ${ }_{\mathrm{x}}$ films with metallic behavior at high Ni/Ti ratios for better solar control windows," App. Phys. Lett., 75, 5, 630 (1999).

200. A. Schüler, V. Thommen, P. Reimann, P. Oelhafen, G. Francz, T. Zehnder, M. Düggelin, D. Mathys, and R. Guggenheim, "Structural and optical properties of titanium aluminum nitride films $\left(\mathrm{Ti}_{1-\mathrm{x}}\right.$ $\left.\mathrm{Al}_{\mathrm{x}} \mathrm{N}\right)$, , J. Vac. Sci. Technol. A, 19, 3, 922 (2001).

201.A. H. Muenker and A. R. Young II, U.S. Patent No. 4,211,210, 8 July 1980; A. H. Muenker and A. R. Young II, U.S. Patent No. 4,268,319, 19 May 1981.

202.J. W. Griffin, K. A. Stahl, and R. B. Pettit, "Optical properties of solid particle receiver materials," Solar Energy Mater., 14, 395 (1988).

203. Shell, "Modified manufacturing process yields uniform silica spheres," NASA Tech. Briefs, 20, February 2002; M. Afghan and J. Sponselee, U.S. Patent No. 4,640,807, 3 February 1987.

204.R. W. Phillips, T. Mayer, and G. S. Ash, U. S. Patent No. 5,648,165, 15 July 1997.

205.M. Matsushita and S. Inamura, U.S. Patent No. 6,210,625, 3 April 2001.

206.K. E. Coulter, T. Mayer, R. W. Phillips, and J. S. Matteucci, U.S. Patent No. 6,150,022, 21 November 2000; R. W. Phillips, T. Mayer, and G. S. Ash, U.S. Patent No. 5,653,792, 5 August 1997; R. W. Phillips, T. Mayer, and G. S. Ash, U.S. Patent No. 5,383,995, 24 September 1995; R. W. Phillips, T. Mayer, and G. S. Ash, U.S. Patent No. 5,281,480, 25 January 1994; R. W. Phillips, T. Mayer, and G. S. Ash, U.S. Patent No. 5,171,363, 15 December 1992; R. W. Phillips, T. Mayer, and G. S. Ash, U.S. Patent No. 5,135,812, 4 August 1992; R. W. Phillips, T. Mayer, and G. S. Ash, U.S. Patent No. 5,084,351, 28 January 1992; R. W. Phillips, T. Mayer, and G. S. Ash, U.S. Patent No. 5,059,245, 22 October 1991; G. S. Ash, U.S. Patent No. 4,434,010, 5 August 1984. 
207.R. N. Hubbard, T. D. Gulden, and M. T. Martin, U.S. Patent No. 6,235,105, 22 May 2001.

208.S. J. Oldenburg, R. D. Averitt, and N. J. Halas, U.S. Patent No. 6,344,272, 5 February 2002.

209.W. R. Wade and W. S. Slemp, "Measurements of total emittance of several refractory oxides, cermets, and ceramics for temperature from $600^{\circ} \mathrm{F}$ to $2,000^{\circ} \mathrm{F}, " N A S A$ Technical Note D-99, (1962).

210.E. Kimmel, "Refractory paints tame hot spots," Res. Dev., 28, 3, (1986).

211.C. Nelson and A. R. Mahoney, "The effect of vitrification temperature upon the solar average absorptance properties of Pyromark ${ }^{\circledR}$ series 2500 black paint," SAND-86-0675, Albuquerque, NM: Sandia National Laboratory, 1986.

212. J. J. Cuomo, J. F. Ziegler, and J. M. Woodall, "A new concept for solar energy thermal conversion," Appl. Phys. Lett., 26, 10, 557 (1975).

213.G. L. Harding and M. R. Lake, "Sputter etched metal solar selective absorbing surfaces for high temperature thermal collectors," Solar Energy Mater., 5, 445 (1981).

214.R. T. Kivaisi and L. Stensland, "Spectral selectivity of nickel and chromium rough surfaces," Appl. Phys. A, 27, 233 (1982).

215.H. G. Craighead and R. E. Howard, U.S. Patent No. 4,284,689, 18 August 1981; L. R. Gilbert, R. F. Messier, and R. Roy, U.S. Patent No. 4,252,865.

216.M. K. Debe, U.S. Patent No. 5,645,929, 8 July 1997; M. K. Debe, U.S. Patent No. RE35,692, 16 December 1997; M. K. Debe, U.S. Patent No. 5,336558, 9 August 1994. 
Appendix 


\section{List of Symbols}

\begin{tabular}{|c|c|}
\hline Symbol & Definition \\
\hline$\alpha$ & solar absorptance \\
\hline$\theta$ & incidence angle of light \\
\hline$d_{p}$ & pore diameter \\
\hline $\mathrm{eV}$ & electron volt \\
\hline $\mathrm{h}$ & hours \\
\hline$\mu \mathrm{m}$ & microns \\
\hline$r$ & particle radius \\
\hline$\rho$ & reflectance \\
\hline $\mathrm{T}$ & temperature \\
\hline$\varepsilon$ & thermal emittance \\
\hline$\lambda$ & wavelengths \\
\hline$\Delta \mathrm{E}_{\mathrm{w}}$ & work function \\
\hline
\end{tabular}




\section{List of Abbreviations}

\begin{tabular}{|c|c|}
\hline $\mathrm{AM}$ & Air-mass \\
\hline AR & Antireflective \\
\hline ARE & Activated reactive evaporation \\
\hline ASTM & American Society for Testing and Materials \\
\hline BFM & Bright flake-based metal pigment \\
\hline CRADA & Cooperative research and development agreement \\
\hline CSP & Concentrated Solar Power \\
\hline CVD & Chemical-vapor deposition \\
\hline $\mathrm{DC}$ & Direct current \\
\hline DLC & Diamond Like Carbon \\
\hline DOE & Department of Energy \\
\hline ELI & Energy Laboratories, Inc. \\
\hline $\mathrm{HCE}$ & Heat collection element \\
\hline HMVF & High-metal-volume fraction \\
\hline IAD & Ion assisted deposition \\
\hline IBAD & Ion-beam-assisted deposition \\
\hline IEA & International Energy Agency \\
\hline IR & Infrared \\
\hline LMVF & Low-metal-volume fraction \\
\hline MF & Medium-frequency \\
\hline MSSA & Multilayer spectral selective absorbers \\
\hline NASA & National Aeronautics and Space Administration \\
\hline NREL & National Renewable Energy Laboratory in Golden, CO \\
\hline $\mathrm{PC}$ & Performance criterion \\
\hline PECVD & Plasma Enhanced Chemical Vapor Deposition \\
\hline PNNL & Pacific Northwest National Laboratories \\
\hline PVD & Physical vacuum deposition \\
\hline $\mathrm{RF}$ & Radio frequency \\
\hline RH & Relative humidity in percent \\
\hline SS & Stainless steel \\
\hline Sun $\diamond \mathrm{Lab}$ & $\begin{array}{l}\text { NREL and Sandia National Laboratory virtual laboratory under the DOE CSP } \\
\text { program }\end{array}$ \\
\hline III-V & $\begin{array}{l}\text { Elements from the in the periodic chart from group IIIB } \\
\text { (i.e., B, Al, Ga, In, and Th) and VB (i.e., N, P, As, Sb, Bi) }\end{array}$ \\
\hline TSSS & Thickness-sensitive spectrally selective \\
\hline UVAC & Universal Vacuum Collector \\
\hline UV & Ultraviolet \\
\hline VF & Metal volume fractions \\
\hline VLS & Vapor-liquid-solid \\
\hline
\end{tabular}




\section{Material Abbreviations}

\begin{tabular}{|c|c|c|c|}
\hline$a-\mathrm{C}: \mathrm{H}$ & $\begin{array}{l}\text { Amorphous hydrogenated } \\
\text { carbon }\end{array}$ & $\begin{array}{l}\mathrm{GaAs} \\
\mathrm{Ge}\end{array}$ & $\begin{array}{l}\text { Gallium arsenide } \\
\text { Germanium }\end{array}$ \\
\hline$a-\mathrm{Si}$ & Amorphous silicon & Hf & Hafnium \\
\hline $\mathrm{Ag}$ & Silver & $\mathrm{HfC}$ & Hafnium carbide \\
\hline $\mathrm{Al}$ & Aluminum & $\mathrm{HfN}$ & Hafnium nitride \\
\hline $\mathrm{AlCuFe}$ & Quasicrystal alloy & $\mathrm{HfN}_{\mathrm{x}}$ & Hafnium subnitride \\
\hline $\mathrm{AlCuFeCr}$ & Quasicrystal alloy & $\mathrm{HNO}_{3}$ & Nitric acid \\
\hline $\mathrm{AlCuRu}$ & Quasicrystal alloy & In & Indium \\
\hline $\mathrm{AlMnPd}$ & Quasicrystal alloy & $\mathrm{In}_{2} \mathrm{O}_{3}$ & Indium oxide \\
\hline $\mathrm{Al}_{2} \mathrm{O}_{3}$ & Aluminum oxide or alumina & $\mathrm{In}_{2} \mathrm{SO}_{3}$ & Indium sulfite \\
\hline $\mathrm{AlO}_{\mathrm{x}}$ & Aluminum suboxide & $\mathrm{K}_{2} \mathrm{~S}_{2} \mathrm{O}_{8}$ & Potassium alkaline bath \\
\hline $\mathrm{AlON}$ & Aluminum oxynitride & $\mathrm{LaB}_{6}$ & Lanthanum boride \\
\hline AlN & Aluminum nitride & $\mathrm{Li}$ & Lithium \\
\hline $\operatorname{AlN}_{x}$ & Aluminum subnitride & $\mathrm{Mg}$ & Magnesium \\
\hline $\mathrm{Al}_{3} \mathrm{Ni}$ & Aluminum-nickel alloy or & $\mathrm{Mg}_{2} \mathrm{Ca}$ & Magnesium calcium alloy \\
\hline & Trialuminides & $\mathrm{MgF}_{2}$ & Magnesium fluoride \\
\hline AMA & $\mathrm{Al}_{2} \mathrm{O}_{3}-\mathrm{Mo}-\mathrm{Al}_{2} \mathrm{O}_{3}$ & $\mathrm{MgO}$ & Magnesium oxide \\
\hline Ar & Argon & $\mathrm{Mn}$ & Manganese \\
\hline $\mathrm{Au}$ & Gold & $\mathrm{Mn}_{2} \mathrm{O}_{3}$ & Manganese oxide \\
\hline As & Arsenic & Mo & Molybdenum \\
\hline $\mathrm{Bi}$ & Bismuth & $\mathrm{MoO}_{3}$ & Molybdenum oxide \\
\hline B & Boron & $\mathrm{Mo}-\mathrm{MoO}_{2}$ & Black moly \\
\hline $\mathrm{BlCu}-\mathrm{Cu}_{2} \mathrm{O}: \mathrm{Cu}$ & Black copper & Mylar & Brand of polyester or PET \\
\hline $\mathrm{Ca}$ & Calcium & $\mathrm{N}$ & Nitrogen \\
\hline $\mathrm{CaF}_{2}$ & Calcium fluoride & $\mathrm{Nb}_{2} \mathrm{O}_{5}$ & Niobium oxide \\
\hline $\mathrm{CdO}$ & Cadmium oxide & $\mathrm{NbB}_{2}$ & Niobium boride \\
\hline $\mathrm{CeO}_{2}$ & Cerium oxide & $\mathrm{Nd}_{2} \mathrm{O}_{3}$ & Neodymium oxide \\
\hline $\mathrm{CeN}$ & Cerium nitride & $\left(\mathrm{NH}_{3}\right)_{\mathrm{aq}}$ & Ammonia, aqueous \\
\hline $\mathrm{CF}_{4}$ & Carbon Tetrafluoride & $\mathrm{Ni}$ & Nickel \\
\hline $\mathrm{CH}_{3} \mathrm{~F}$ & Methyl fluoride & $\mathrm{NiCrO}_{x}$ & Nickel chromium suboxide \\
\hline $\mathrm{Co}$ & Cobalt & NiS-ZnS & Black Nickel \\
\hline $\mathrm{CoO}$ & Cobalt monoxide & $\mathrm{P}$ & Phosphorus \\
\hline $\mathrm{Co}_{3} \mathrm{O}_{4}$ & Cobalt oxide & $\mathrm{Pb}$ & Lead \\
\hline $\mathrm{Co}_{\mathrm{x}} \mathrm{O}_{\mathrm{y}}$ & Cobalt suboxide & $\mathrm{PbS}$ & Lead sulfide \\
\hline $\mathrm{Co}_{3} \mathrm{O}_{4} / \mathrm{Co}$ & Black cobalt & $\mathrm{Pd}$ & Palladium \\
\hline $\mathrm{Cr}$ & Chromium & PET & Polyethylene terephthalate or polyester \\
\hline $\mathrm{Cr}_{3} \mathrm{C}_{2}$ & Chromium carbide & $\mathrm{Pt}$ & Platinum \\
\hline $\mathrm{Cr}_{2} \mathrm{O}_{3}$ & Chromium oxide & $\mathrm{ReO}_{3}$ & Rhenium oxide \\
\hline $\mathrm{CrO}_{\mathrm{x}}$ & Chromium suboxide & $\mathrm{Rh}_{2} \mathrm{O}_{3}$ & Rhodium oxide \\
\hline $\mathrm{CrN}$ & Chrome nitride & $\mathrm{Sb}$ & Antimony \\
\hline $\mathrm{Cr}-\mathrm{Cr}_{2} \mathrm{O}_{3}$ & Black chrome & $\mathrm{Si}$ & Silicon \\
\hline $\mathrm{CuFeMnO}_{4}$ & Pigment & $\mathrm{SiO}$ & Silicon monoxide \\
\hline $\mathrm{Cu}$ & Copper & $\mathrm{SiO}_{2}$ & Silicon dioxide or silica \\
\hline $\mathrm{CuO}$ & Copper oxide & $\mathrm{Si}_{3} \mathrm{~N}_{4}$ & Silicon nitride \\
\hline $\mathrm{Eu}_{2} \mathrm{O}_{3}$ & Europium oxide & $\mathrm{SiO}_{\mathrm{x}} \mathrm{N}_{\mathrm{y}}$ & Silicon oxynitride \\
\hline $\mathrm{EuN}$ & Europium nitride & $\mathrm{Sn}$ & Tin \\
\hline $\mathrm{F}$ & Fluorine & $\mathrm{SnO}_{2}$ & Tin oxide \\
\hline $\mathrm{Fe}$ & Iron & $\mathrm{Sn}_{\mathrm{x}} \mathrm{O}_{\mathrm{x}}$ & Tin suboxide \\
\hline $\mathrm{Fe}_{2} \mathrm{O}_{3}$ & Iron oxide or hematite & $\mathrm{SnO}_{\mathrm{x}}: \mathrm{F}$ & Fluorine-doped tin oxide \\
\hline $\mathrm{Fe}_{3} \mathrm{O}_{4}$ & Magnetite & $\mathrm{SrF}_{2}$ & Strontium fluoride \\
\hline $\mathrm{Fe}+\mathrm{Mn}_{3} \mathrm{O}_{4}$ & Jacobtite & $\mathrm{Ta}$ & Tantalum \\
\hline $\mathrm{Ga}$ & Gallium & & \\
\hline
\end{tabular}




\begin{tabular}{|c|c|}
\hline $\mathrm{TaB}_{2}$ & Tantalum boride \\
\hline $\mathrm{TaC}$ & Tantalum carbide \\
\hline $\mathrm{Ta}_{2} \mathrm{O}_{5}$ & Tantalum oxide \\
\hline $\mathrm{TaN}$ & Tantalum nitride \\
\hline TEOS & Tetraethoxysilane \\
\hline 3-APTES & 3-aminopropyl-triethoxysilane \\
\hline $\mathrm{Ti}$ & Titanium \\
\hline $\mathrm{Ti}_{1-\mathrm{x}} \mathrm{Al}_{\mathrm{x}} \mathrm{N}$ & Titanium aluminum nitride \\
\hline $\mathrm{TiB}_{2}$ & Titanium \\
\hline TiN & Titanium nitride \\
\hline $\operatorname{TiN}_{\mathrm{x}}$ & Titanium subnitride \\
\hline $\mathrm{TiN}_{\mathrm{x}} \mathrm{O}_{\mathrm{y}}$ & Titanium oxynitride \\
\hline $\mathrm{TiO}_{2}$ & Titanium oxide or titania \\
\hline $\mathrm{TiO}_{\mathrm{x}}$ & Titanium suboxide \\
\hline $\mathrm{TiSi}_{2}$ & Titanium silicide \\
\hline $\mathrm{Tl}$ & Thallium \\
\hline V & Vanadium \\
\hline $\mathrm{VB}_{2}$ & Vanadium boride \\
\hline $\mathrm{V}_{2} \mathrm{O}_{5}$ & Vanadium oxide \\
\hline $\mathrm{W}$ & Tungsten \\
\hline $\mathrm{WC}$ & Tungsten carbide \\
\hline $\mathrm{WO}_{\mathrm{x}}$ & Tungsten oxide \\
\hline $\mathrm{W}-\mathrm{WO}_{\mathrm{x}}$ & Black Tungsten \\
\hline $\mathrm{WSi}_{2}$ & Tungsten silicide \\
\hline $\mathrm{Y}_{2} \mathrm{O}_{3}$ & Yttrium oxide \\
\hline $\mathrm{YN}$ & Yttrium nitride \\
\hline $\mathrm{Zn}$ & Zinc \\
\hline $\mathrm{ZnO}$ & Zinc oxide \\
\hline $\mathrm{ZnS}$ & Zinc sulfide \\
\hline $\mathrm{Zr}$ & Zirconium \\
\hline $\mathrm{ZrAl}_{3}$ & Zirconium trialuminides \\
\hline $\mathrm{ZrB}_{2}$ & Zirconium boride \\
\hline $\mathrm{ZrC}$ & Zirconium carbide \\
\hline $\mathrm{ZrC}_{\mathrm{x}}$ & Zirconium subcarbide \\
\hline $\mathrm{ZrC}_{\mathrm{x}} \mathrm{N}_{\mathrm{y}}$ & Zirconium carbonitride \\
\hline $\mathrm{ZrC}_{\mathrm{x}} \mathrm{O}_{\mathrm{y}} \mathrm{N}_{\mathrm{z}}$ & Zirconium carboxynitride \\
\hline $\mathrm{ZrO}_{2}$ & Zirconium oxide \\
\hline $\mathrm{ZrO}_{\mathrm{x}}$ & Zirconium suboxide \\
\hline $\mathrm{ZrO}_{\mathrm{x}} \mathrm{N}_{\mathrm{y}}$ & Zirconium oxynitride \\
\hline $\mathrm{ZrN}$ & Zirconium nitride \\
\hline
\end{tabular}




\section{Definitions}

Activated reactive evaporation (ARE): to make gas reactive or more reactive by partially ionizing them during evaporation.

Bandgap: the minimum energy separation between the highest occupied state and the lowest empty state, that determines the temperature dependence of the electrical conductivity of a pure semiconductor.

Biomimetic: human-made processes, substances, devices, or systems that imitate nature..

Calcine: to heat inorganic materials to a high temperature but without fusing in order to drive off volatile matter or to effect changes (as oxidation or pulverization).

Cermet: Metal-dielectric composites, a composite structural material of a heat-resistant compound (as titanium carbide) and a metal (as nickel).

Codeposition: to deposit two or more materials at the same time to form a compound.

Cubic: relating to a crystallographic system characterized by three equal axes at right angles.

Dendrite: a branching treelike figure produced on or in a mineral by a foreign mineral.

Doped: to treat with a dopant, an impurity added usually in minute amounts to a pure substance to alter its properties.

Eutectic: an alloy or solution having the lowest melting point possible or relating to a eutectic alloy or solution and its melting or freezing point.

Evaporation: to deposit (as a metal) in the form of a film by sublimation.

Fresnel: a lens that has a surface consisting of a concentric series of simple lens sections so that a thin lens with a short focal length and large diameter is possible and that is used especially for spotlights.

Icosahedral: relating to or being a crystallographic system having the form of an icosahedron, a polyhedron having 20 faces.

Lamellar: composed of or arranged in lamellae, a thin flat plate or layer.

Lithography: the process of producing patterns on semiconductor crystals for use as integrated circuits

Magnetron sputtering: a diode vacuum tube in which the flow of electrons is controlled by an externally applied magnetic field to generate power at microwave frequencies to dislodge atoms from the surface of a material by collision with high energy particles; also to deposit (a metallic film) by such a process.

Mercaptan: any of various compounds that contain a thiol functional group; various compounds having the general formula RSH which are analogous to alcohols but in which sulfur replaces the oxygen of the hydroxyl group and which have disagreeable odors.

Metallo-organic: an organic compound with a metal functional group.

Microcrystallites: a crystal structure visible only under the microscope.

Microstructure: the microscopic structure of a material (as a mineral or a biological cell).

Monoclinic: a crystal system characterized by three unequal axes with one oblique intersection .

Morphology: the external form and structure of a material or topographic features.

Passivated: to make inactive or less reactive (passivate the surface of steel by chemical treatment) or to protect (as a solid-state device) against contamination by coating or surface treatment.

Pyrolysis: chemical change brought about by the action of heat. 
Quasicrystal: a body of solid material that resembles a crystal in being composed of repeating structural units but that incorporates two or more unit cells into a quasiperiodic structure.

Reactive: to deposit a material in the presence of a chemical or gas in order to cause a chemical transformation or change; the interaction of chemical entities; the state resulting from such a reaction; a process involving change in atomic nuclei.

Resist: a coating that protects against a chemical, electrical, or physical action typically during lithography.

Resinate: to impregnate or flavor with resin, any various products made from a natural resin or a natural polymer. Natural resin: any of various solid or semisolid amorphous fusible flammable natural organic substances that are usually transparent or translucent and yellowish to brown, are formed especially in plant secretions, are soluble in organic solvents (as ether) but not in water, are electrical nonconductors, and are used chiefly in varnishes, printing inks, plastics, and sizes and in medicine. Natural polymer; any of a large class of synthetic products that have some of the physical properties of natural resins but are different chemically and are used chiefly in plastics.

Rutile: mineral that consists of titanium dioxide usually with a little iron, is typically of a reddish brown color but sometimes deep red or black, and has a brilliant metallic or adamantine luster.

Sol-gel : deposition process involving alternation between sol and gel states.

Solidification: to make solid, compact, or hard.

Spinel: a hard crystalline mineral consisting of an oxide of magnesium and aluminum that varies from colorless to ruby-red to black and is used as a gem or any of a group of minerals that are essentially oxides of magnesium, ferrous iron, zinc, or manganese.

Sputtering: to dislodge atoms from the surface of a material by collision with high energy particles; also to deposit (a metallic film) by such a process.

Stoichiometry: the quantitative relationship between constituents in a chemical substance.

Sublimation decomposition: to separate into constituent parts or elements or into simpler compounds by sublimation (i.e. melting) that is to pass directly from the solid to the vapor state and condense back to solid form.

Tetragonal: a crystal system characterized by three axes at right angles of which only the two lateral axes are equal. 


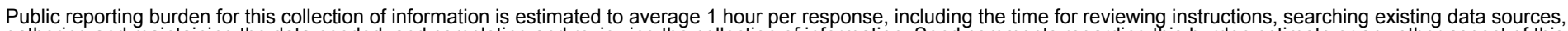

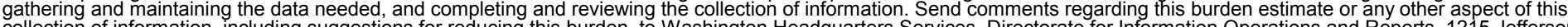
Davis Highway, Suite 1204, Arlington, VA 22202-4302, and to the Office of Management and Budget, Paperwork Reduction Project (0704-0188), Washington, DC 20503.

\begin{tabular}{|l|l|l|l|}
\hline 1. AGENCY USE ONLY (Leave blank) & $\begin{array}{c}\text { 2. REPORT DATE } \\
\text { July } 2002\end{array}$ & $\begin{array}{c}\text { 3. REPORT TYPE AND DATES COVERED } \\
\text { Technical Report }\end{array}$ \\
\hline 4. TITLE AND SUBTITLE &
\end{tabular}

4. TITLE AND SUBTITLE
Review of Mid- to High-Temperature Solar Selective Absorber Materials

6. AUTHOR(S) C.E. Kennedy

7. PERFORMING ORGANIZATION NAME(S) AND ADDRESS(ES) National Renewable Energy Laboratory 1617 Cole Blvd. Golden, CO 80401-3393

9. SPONSORING/MONITORING AGENCY NAME(S) AND ADDRESS(ES) National Renewable Energy Laboratory 1617 Cole Blvd. Golden, CO 80401-3393

5. FUNDING NUMBERS CP02.2000

8. PERFORMING ORGANIZATION REPORT NUMBER

10. SPONSORING/MONITORING AGENCY REPORT NUMBER

NREL/TP-520-31267

11. SUPPLEMENTARY NOTES

12a. DISTRIBUTION/AVAILABILITY STATEMENT

National Technical Information Service

U.S. Department of Commerce

5285 Port Royal Road

Springfield, VA 22161 12b. DISTRIBUTION CODE

13. ABSTRACT (Maximum 200 words) This report describes the concentrating solar power (CSP) systems using solar absorbers to convert concentrated sunlight to thermal electric power. It is possible to achieve solar absorber surfaces for efficient photothermal conversion having high solar absorptance $(\alpha)$ for solar radiation and a low thermal emittance $(\varepsilon)$ at the operational temperature. A low reflectance $(\rho \approx 0)$ at wavelengths $(\lambda) \leq 3 \mu \mathrm{m}$ and a high reflectance $(\rho \approx 1)$ at $\lambda \geq 3 \mu \mathrm{m}$ characterize spectrally selective surfaces. The operational temperature ranges of these materials for solar applications can be categorized as low temperature $\left(\mathrm{T}<100^{\circ} \mathrm{C}\right)$, mid-temperature $\left(100^{\circ} \mathrm{C}<\mathrm{T}<400^{\circ} \mathrm{C}\right)$, and high-temperature $\left(\mathrm{T}>400^{\circ} \mathrm{C}\right)$. High- and mid-temperature applications are needed for CSP applications. For CSP applications, the ideal spectrally selective surface would be low-cost and easy to manufacture, chemically and thermally stable in air at elevated operating temperatures $\left(\mathrm{T} \geq 500^{\circ} \mathrm{C}\right)$, and have a solar absorptance $\geq 0.98$ and a thermal emittance $\leq 0.05$ at $500^{\circ} \mathrm{C}$.

SUBJECT TERMS: PV; concentrating solar power (CSP); solar absorber surfaces; spectral emittance; intrinsic absorbers; semiconductor-metal tandems; solar-selective coating; cermet layer; nanoparticles; photothermal conversion

17. SECURITY CLASSIFICATION OF REPORT

Unclassified
18. SECURITY CLASSIFICATION OF THIS PAGE Unclassified
19. SECURITY CLASSIFICATION OF ABSTRACT Unclassified
15. NUMBER OF PAGES

16. PRICE CODE

20. LIMITATION OF ABSTRACT

UL 